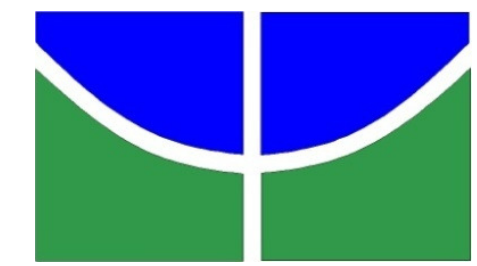

UNIVERSIDADE DE BRASÍLIA

FACULDADE DE DIREITO

Rodrigo Melo do Nascimento

OS TRIBUNAIS DE CONTAS

E A EXECUÇÃO JUDICIAL DE SUAS DECISÕES 
Rodrigo Melo do Nascimento

\section{OS TRIBUNAIS DE CONTAS \\ E A EXECUÇÃO JUDICIAL DE SUAS DECISÕES}

Monografia apresentada à Faculdade de Direito da Universidade de Brasília, como requisito parcial para obtenção do grau de bacharel em Direito.

Orientador: Professor Doutor Antônio de Moura Borges 
Nascimento, Rodrigo Melo do.

Os Tribunais de Contas e a Execução Judicial de suas Decisões / Rodrigo Melo do Nascimento. -- Brasília: UnB / Faculdade de Direito, 2011.

94 f. : il.

Orientador: Antônio de Moura Borges.

Monografia (graduação) - Universidade de Brasília, Faculdade de Direito, 2011.

1. Decisões condenatórias em julgamentos de contas. 2. Natureza jurídica das decisões condenatórias. 3. Execução judicial das decisões condenatórias. 3. Direito Administrativo e Processual Civil - Monografia de Graduação. I. Universidade de Brasília, Faculdade de Direito. II. Borges, Antônio de Moura, orient. III. Título. 
Rodrigo Melo do Nascimento

OS TRIBUNAIS DE CONTAS

E A EXECUÇÃO JUDICIAL DE SUAS DECISÕES

Monografia apresentada à Faculdade de Direito da Universidade de Brasília, como requisito parcial para obtenção do grau de bacharel em Direito.

Data de aprovação: 29 / 11 / 2011.

Conceito: SS

Banca examinadora:

Prof. Dr. Antônio de Moura Borges - Orientador Universidade de Brasília (UnB)

Paulo Soares Bugarin - Membro

Mestre em Direito, Estado e Constituição - UnB

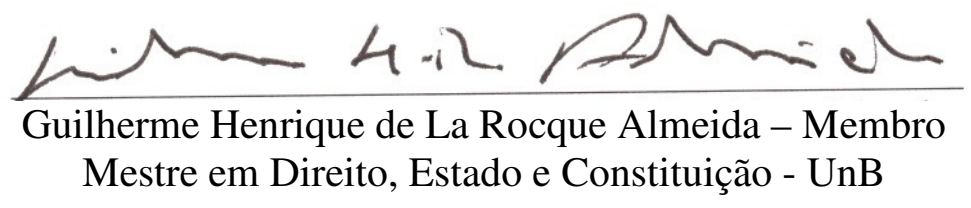


A meu eterno avô Gilberto do Nascimento, médico e odontólogo, um exemplo de homem. 


\section{AGRADECIMENTOS}

Em primeiro lugar, a Deus, autor e consumador da vida, que nos oferece gratuitamente a salvação unicamente por meio de seu filho unigênito Jesus Cristo.

A minha esposa Adriana, pelo amor e inestimável apoio ao longo desses anos de graduação.

A meus pais, Gilberto e Léa, que sempre investiram em minha formação intelectual.

Ao Dr. Paulo Soares Bugarin, Subprocurador-Geral do MP/TCU, pelas pertinentes sugestões, oferecidas sempre com extrema autoridade, mas também com admirável simplicidade.

Ao amigo e colega do TCU, Luciano Carlos Batista, pelas sugestões e pelo aprendizado que me proporcionou no biênio 2009/2010 a partir de sua vasta experiência de Casa.

À amiga e colega do TCU, Marisa Alho Mattos de Carvalho, pelo extraordinário profissionalismo e pela confiança que sempre depositou em mim.

À amiga e colega do TCU, Maria Antônia Ferraz Zelenovsky, pelos sábios conselhos nos momentos difíceis.

Aos amigos e ex-colegas do TCM-RJ, com quem tive a oportunidade de trabalhar na $5^{\text {a }}$ Inspetoria-Geral de Controle Externo de 2003 a 2008, e que me ensinaram os primeiros passos no controle externo.

À Faculdade de Direito da Universidade do Estado do Rio de Janeiro (UERJ), onde cursei meus 2 primeiros anos de graduação (2005/2006).

À Faculdade de Direito da Universidade de Brasília (UnB), pela sólida formação acadêmica que me proporcionou. 
"O Governo Provisório reconheceu a urgência inevitável de reorganizá-lo [o sistema de contabilidade orçamentária]; e acredita haver lançado os fundamentos para essa reforma radical com a criação de um Tribunal de Contas, corpo de magistratura intermediária à administração e à legislatura, que colocado em posição autônoma, com atribuições de revisão e julgamento, cercado de garantias contra quaisquer ameaças, possa exercer as suas funções vitais no organismo constitucional, sem o risco de converter-se em instituição de ornato aparatoso e inútil" (Rui Barbosa, Ministro da Fazenda, na Exposição de Motivos ao Decreto $n^{\circ}$ 966-A, de 7 de novembro de 1890, que criou o Tribunal de Contas da União). 


\section{RESUMO}

Entre as competências atribuídas constitucionalmente aos Tribunais de Contas brasileiros, destaca-se aquela relativa ao julgamento de contas dos responsáveis por recursos públicos. Tal competência decorre do exercício de autêntica função jurisdicional, ocorrendo no bojo de um processo administrativo de contas, em que são garantidos o contraditório e a ampla defesa, inclusive mediante a interposição de recursos. Afigura-se incabível a reforma, pelo Poder Judiciário, de decisão condenatória proferida pelos Tribunais de Contas, ressalvada a ocorrência de eventual ilegalidade manifesta ou irregularidade formal. Em sendo proferida decisão pela irregularidade das contas, imputando débito ou cominando multa, e não sendo recolhida a dívida no prazo legal pelo responsável, o acórdão condenatório possui eficácia de título executivo extrajudicial, cabendo o ajuizamento de sua execução pelos órgãos competentes. Tal processo de execução judicial deve obedecer ao rito legalmente previsto para a execução fiscal, pois os valores condenatórios são dívida ativa não tributária. Em que pese isto, o devedor não pode alegar em sede de embargos à execução qualquer matéria que lhe seria lícito deduzir como defesa no processo de conhecimento, pois a cognição da matéria já ocorreu por ocasião do julgamento de suas contas. Tendo em vista a polêmica questão da efetividade na recuperação judicial dos valores condenatórios, mister se faz cogitar acerca de meios que possam otimizar tal recuperação. Oportuno ainda pensar alternativas à própria sistemática vigente de execução judicial dos títulos condenatórios, refletindo-se acerca da atribuição de capacidade postulatória ativa aos Tribunais de Contas e sobre a autoexecutoriedade das decisões.

Palavras-chaves: Tribunais de Contas. Julgamento de contas. Natureza jurídica das decisões. Eficácia de título executivo. Execução judicial. 


\begin{abstract}
Among the competences assigned constitutionally to the Brazilian Courts of Audit, that concerning to the account judgment of agents responsible for public funds is to be detached. Such competence comes from the practice of an authentic jurisdictional function, occurring by means of an administrative account process, in which are guaranteed the contradictory and the wide defense, inclusively through appeal interposition. It is not possible to the judicial branch to change a condemnatory decision from the Courts of Audit, except for the occurrence of an evident illegality or a formal irregularity. If it is given a judgment deciding for the account irregularity, attributing a debt or imposing a penalty, and if it the obligation is not paid in the legal term by the condemned agent, the condemnatory decision has an extrajudicial executive title efficacy, which permits the bringing of a prosecution by the competent offices. Such judicial prosecution process must obey the same legal proceedings prescribed for the government prosecutions, because the condemnatory values are non-tributary active debts. Nevertheless, the debtor cannot argue any matter that would be licit to bring forward as defense on the acknowledgement process, since the matter cognition would have already taken place at the opportunity of the account judgment. On the basis of the polemic matter about the effectiveness of judicial recovery of condemnatory values, it is necessary to cogitate on the potential means to optimize that recovery. It is also propitious to think about alternatives to the systematics in vigour regarding the judicial prosecution of condemnatory titles, reflecting upon the assignment of active postulatory capacity to the Courts of Audit and the self-prosecution of decisions.
\end{abstract}

Key-words: Courts of Audit. Account judgment. Juridical nature of decisions. Executive title efficacy. Judicial prosecution. 


\section{LISTA DE ABREVIATURAS E SIGLAS}

(em ordem alfabética)

$\begin{array}{ll}\text { ADI } & \text { - Ação direta de inconstitucionalidade } \\ \text { AGU } & \text { - Advocacia-Geral da União } \\ \text { AI } & \text { - Agravo de instrumento } \\ \text { CF } & \text { - Constituição Federal de 1988 } \\ \text { CPC } & \text { - Código de Processo Civil } \\ \text { IN } & \text { - Instrução Normativa } \\ \text { LOTCU } & \text { - Lei Orgânica do Tribunal de Contas da União } \\ \text { LEF } & \text { - Lei de Execuções Fiscais } \\ \text { MP/TCU } & \text { - Ministério Público junto ao Tribunal de Contas da União } \\ \text { MP/TCE-RS } & \text { - Ministério Público junto ao Tribunal de Contas do Estado do Rio Grande do } \\ \text { MS } & \text { Sul } \\ \text { PEC } & \text { - Mandado de Segurança } \\ \text { PGF } & \text { - Proposta de Emenda à Constituição } \\ \text { PGU } & \text { - Procuradoria-Geral Federal } \\ \text { RE } & \text { - Procuradoria-Geral da União } \\ \text { REsp } & \text { - Recurso extraordinário } \\ \text { RITCU } & \text { - Recurso especial } \\ \text { STF } & \text { - Regimento Interno do Tribunal de Contas da União } \\ \text { STJ } & \text { - Supremo Tribunal Federal } \\ \text { TCDF } & \text { - Superior Tribunal de Justiça } \\ \text { TCU } & \text { - Tribunal de Contas do Distrito Federal } \\ \text { - Tribunal de Contas do Estado } \\ \text { - Tribunal de Contas do(s) Município(s) }\end{array}$




\section{SUMÁRIO}

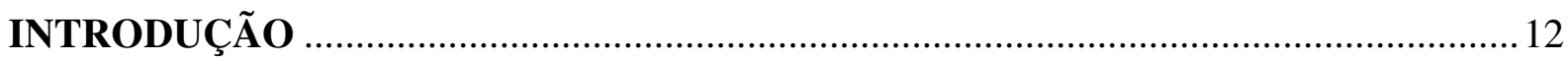

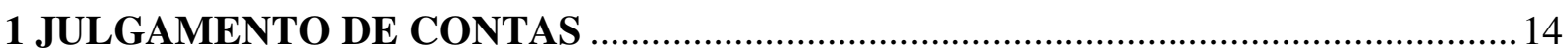

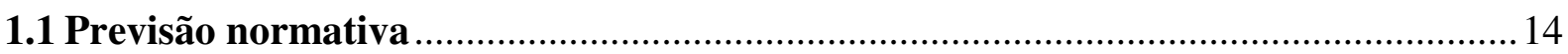

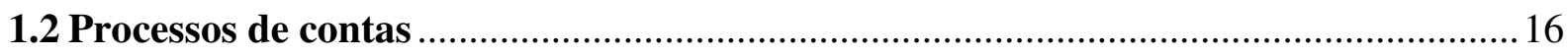

1.2.1 Tomada e prestação de contas ......................................................................................17

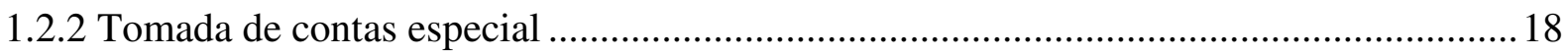

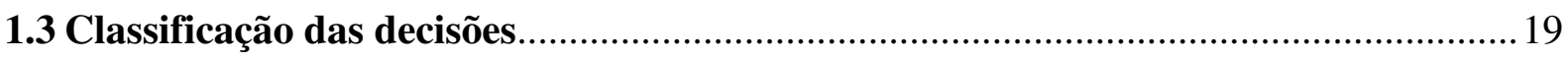

1.4 Execução administrativa das decisões condenatórias ...............................................20

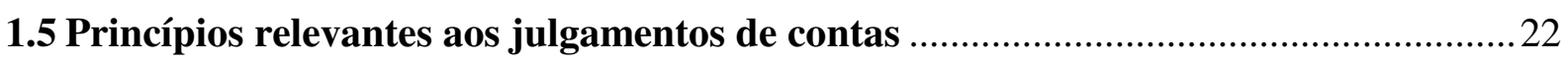

1.5.1 Princípios do contraditório e da ampla defesa...............................................................2 23

1.5.2 Princípio da verdade material .................................................................................24

1.5.3 Princípio do formalismo moderado .......................................................................2

1.5.4 Princípio da racionalização administrativa e economia processual...................................26

2 NATUREZA JURÍDICA, REVISIBILIDADE JUDICIAL E EFICÁCIA DAS

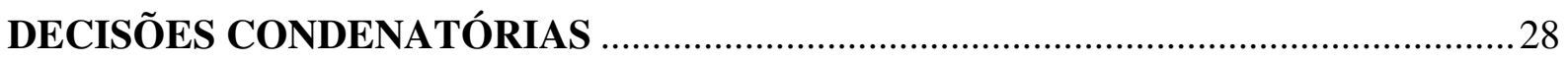

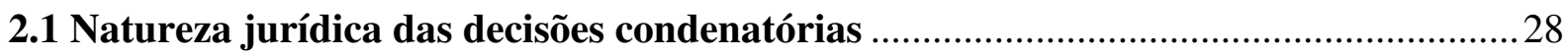

2.1.1 O sistema da unicidade da jurisdição .........................................................................2

2.1.2 As decisões condenatórias como exercício da jurisdição ...................................................30

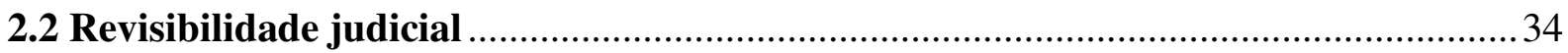

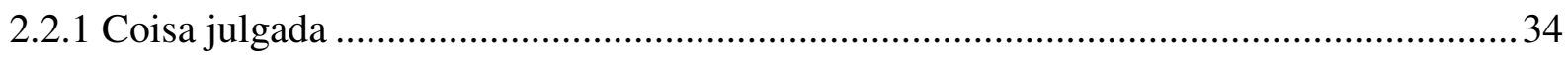

2.2.2 Limites à revisibilidade judicial ................................................................................... 36

2.3 Eficácia das decisões condenatórias …………………………………………….......4

3 EXECUÇÃO JUDICIAL DAS DECISÕES CONDENATÓRIAS …………………......4 49

3.1 A execução de títulos judiciais e extrajudiciais..............................................................4

3.1.1 Execução de títulos judiciais .................................................................................51

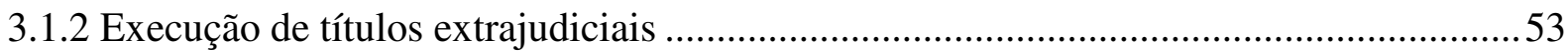

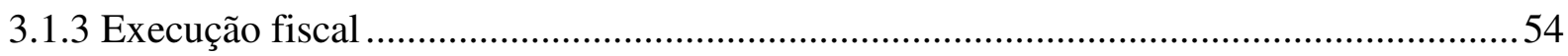

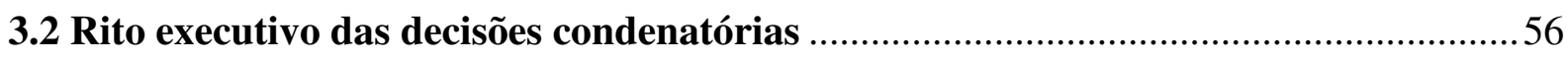

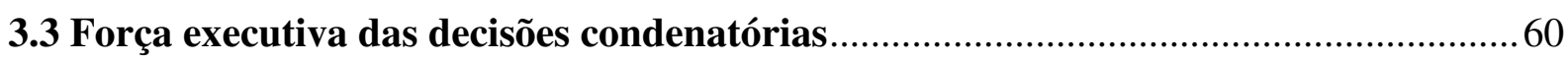

3.4 A questão da efetividade na recuperação judicial dos valores condenatórios .............66

3.4.1 Medidas prévias à decisão condenatória definitiva ………………………………….....68 
3.4.2 Algumas alternativas previstas na legislação processual civil 70

3.4.3 Estratégias para a defesa da jurisdição constitucional de contas . .72

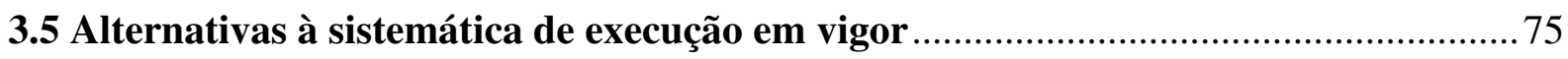

3.5.1 Capacidade postulatória ativa dos Tribunais de Contas ................................................ 78

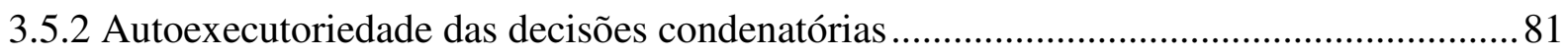

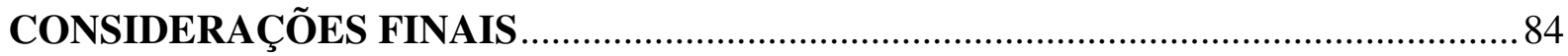

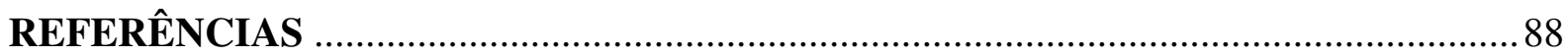




\section{INTRODUÇÃO}

A Constituição Federal de 1988 (CF) consolidou, no panorama institucional da República Federativa do Brasil, a posição ocupada pela instituição Tribunal de Contas, atribuindo-lhe relevantes competências no exercício do controle externo da Administração Pública, seja no âmbito da União, seja naquele de Estados e Municípios.

Entre tais competências, avulta em importância aquela contida nos incisos II e VIII do art. 71 da Carta Cidadã, os quais preveem a atribuição do julgamento de contas, em cujo bojo são passíveis de prolação decisões pela irregularidade das contas, imputando débito ou cominando multa aos responsáveis pela aplicação de recursos públicos ou por eventual dano ao Erário ${ }^{1}$.

Tais decisões condenatórias, conforme estabelecido no $\S 3^{\circ}$ do art. 71 da $\mathrm{CF}$, têm eficácia de título executivo, prestando-se à propositura da competente ação de execução judicial, caso o responsável não recolha a dívida perante o próprio Tribunal de Contas que proferiu o acórdão condenatório, prolatado nos autos de processo administrativo em que são garantidos ao interessado o contraditório e a ampla defesa.

Ocorre que, uma vez ajuizada a ação de execução judicial pelos órgãos competentes, o executado tem a seu dispor, nada obstante a ampla oportunidade de defesa que já lhe foi conferida no processo administrativo de contas, instrumentos previstos na legislação processual civil para combater o acórdão condenatório, destacando-se nesse contexto a figura dos chamados embargos à execução, por meio dos quais muitas vezes o devedor pretende alegar "qualquer matéria que lhe seria lícito deduzir como defesa em processo de conhecimento" (art. 745, V, do Código de Processo Civil - CPC).

Tal excesso de defesa, ao mesmo tempo em que representa afronta à jurisdição constitucional de contas, compromete a efetividade na recuperação judicial dos valores condenatórios e contribui para perpetuar a impunidade na malversação de recursos públicos.

No que toca especificamente à questão da efetividade, a rediscussão de tudo que já restou julgado pelo Tribunal de Contas gera um efeito protelatório indesejável que,

\footnotetext{
${ }^{1}$ Para o julgamento das contas de responsáveis por recursos públicos federais, é competente o Tribunal de Contas da União (TCU); para contas distritais, o Tribunal de Contas do Distrito Federal (TCDF); para contas estaduais e municipais, são competentes os Tribunais de Contas dos Estados, ressalvada a competência, no que se refere às contas municipais, do Tribunal de Contas dos Municípios (TCMs), presente nos Estados da Bahia, Ceará, Goiás e Pará, bem como do Tribunal de Contas do Município, presente apenas nos Municípios do Rio de Janeiro e de São Paulo.
} 
associado à demora na análise, pelos órgãos repassadores, das prestações de contas de convênios e ao próprio tempo necessário para que tais contas sejam julgadas definitivamente pelos Tribunais de Contas, faz com que a efetividade na recuperação judicial dos valores condenatórios diminua drasticamente, de vez que os responsáveis aos quais foi imputado débito ou cominada multa terão tempo suficiente para adotar medidas visando a não deixar patrimônio próprio que responda pela dívida.

Ademais, nesse contexto, faz-se necessário perquirir os eventuais limites aplicáveis à apreciação dos julgamentos de contas pelo Poder Judiciário, a partir da própria natureza jurídica destes julgamentos, sem que se perca de vista o sistema da unicidade da jurisdição, bem como o princípio da inafastabilidade do Poder Judiciário, previstos no inciso XXXV do art. $5^{\circ}$ da CF.

Esta monografia, que se encontra estruturada em três capítulos, tem por objetivo abordar a execução judicial das decisões condenatórias proferidas pelos Tribunais de Contas, a partir de pesquisa doutrinária e jurisprudencial sobre o assunto, bem como da coleta de dados em relatórios gerenciais do Tribunal de Contas da União (TCU) e da Advocacia-Geral da União (AGU).

No primeiro capítulo, aborda-se o rito do processo administrativo de julgamento de contas, tendo-se como referencial a legislação aplicável ao TCU, bem como os princípios que regem tal processualística.

Em seguida, no segundo capítulo, define-se a natureza jurídica dos julgamentos de contas como pré-requisito à delimitação dos limites aplicáveis a sua revisibilidade judicial, tendo-se em conta a eficácia de título executivo outorgada constitucionalmente às decisões condenatórias.

Por fim, no terceiro e último capítulo, procede-se à análise da execução judicial propriamente dita, abordando-se aspectos atinentes a seu rito, inclusive no que se refere aos embargos à execução, sem que se olvide de mencionar algumas alternativas à sistemática de execução em vigor.

Antes do primeiro capítulo, contudo, faz-se mister consignar que, considerando o princípio da simetria existente entre o TCU e os demais Tribunais de Contas, contido no art. 75 da CF, bem como a diversidade de legislações locais, opta-se por uma abordagem tendo-se como pano de fundo normativo a realidade do TCU, sem prejuízo de se tecerem algumas considerações aplicáveis especificamente às demais Cortes de Contas. 


\section{JULGAMENTO DE CONTAS}

Entre as atribuições conferidas aos Tribunais de Contas no ordenamento jurídico brasileiro, assume especial relevo aquela concernente ao julgamento de contas dos administradores de recursos públicos, bem como daqueles responsáveis por irregularidades causadoras de danos ao erário público.

O objetivo deste capítulo é introduzir o leitor àquela que talvez seja a mais relevante das competências conferidas aos Tribunais de Contas ${ }^{2}$, abordando-se questões de natureza processual no âmbito interno destas Cortes.

\subsection{Previsão normativa}

A competência para o julgamento de contas vem sendo tradicionalmente atribuída às Cortes de Contas por força de sucessivas normas de envergadura constitucional ${ }^{3}$. Nesse sentido, preceitua o art. 71, incisos II e VIII, da $\mathrm{CF}^{4}$, verbis:

Art. 71. O controle externo, a cargo do Congresso Nacional, será exercido com o auxílio do Tribunal de Contas da União, ao qual compete:

[...]

II - julgar as contas dos administradores e demais responsáveis por dinheiros, bens e valores públicos da administração direta e indireta, incluídas as fundações e sociedades instituídas e mantidas pelo Poder

2 Segundo Zymler (2009), tal preponderância é decorrência imediata do princípio fundamental da ordem constitucional brasileira que torna obrigatória a prestação de contas da Administração Pública (art. 34, VII, "d" da Constituição), como decorrência da forma republicana de governo, na qual aquele que lida com a res publica está obrigado a comprovar a regularidade de sua gestão, por meio da devida prestação de contas. $\mathrm{O}$ autor afirma que os processos derivados de inspeção ou auditoria são apensados, quando cabível, às contas anuais dos gestores principais, o que atesta o caráter subsidiário e acessório dos processos de fiscalização em relação aos processos de contas. Aqueles reúnem informações preciosas que servem para embasar o julgamento das contas anuais dos gestores públicos.

3 As Constituições Brasileiras de 1934, 1937, 1946, 1967 e 1988 empregam o verbo "julgar” para designar a competência dos Tribunais de Contas para apreciar as contas dos administradores públicos (ZYMLER, 2009). A respeito da previsão da competência de julgamento de contas nas Constituições Brasileiras anteriores a 1988, interessantes as abordagens de Ferraz (1999) e de Costa Júnior (2001).

${ }^{4}$ Importante consignar que, por força do princípio da simetria constitucional, em que pese o fato de o art. $71 \mathrm{da}$ Constituição Federal fazer menção tão-somente ao Tribunal de Contas da União (TCU), as atribuições ali previstas também se aplicam - no que couber - aos Tribunais de Contas dos Estados (TCEs), ao Tribunal de Contas do Distrito Federal (TCDF) e aos Tribunais de Contas do(s) Município(s) (TCMs), conforme preceitua o art. 75 da CF. Todos os vinte e seis Estados da Federação possuem um TCE, o Distrito Federal possui o TCDF e os Estados da Bahia, Ceará, Goiás e Pará possuem um TCM (TCM-BA; TCM-CE; TCM-GO; TCMPA). Além disso, os Municípios do Rio de Janeiro e de São Paulo possuem, como órgão municipal, seu próprio TCM (TCM-RJ e TCM-SP). No País, portanto, somando-se o TCU, os TCEs, o TCDF e os TCMs, há um total de trinta e quatro Tribunais de Contas. 
Público federal, e as contas daqueles que derem causa a perda, extravio ou outra irregularidade de que resulte prejuízo ao erário público;

[...]

VIII - aplicar aos responsáveis, em caso de ilegalidade de despesa ou irregularidade de contas, as sanções previstas em lei, que estabelecerá, entre outras cominações, multa proporcional ao dano causado ao erário;

Já o dever de prestar contas aos Tribunais de Contas está constitucionalmente estabelecido no parágrafo único ${ }^{5}$ do art. 70 da Carta Magna, que estabelece o seguinte:

Parágrafo único. Prestará contas qualquer pessoa física ou jurídica, pública ou privada, que utilize, arrecade, guarde, gerencie ou administre dinheiros, bens e valores públicos ou pelos quais a União responda, ou que, em nome desta, assuma obrigações de natureza pecuniária.

Nesse sentido, a Lei $\mathrm{n}^{\text {o }}$ 8.443, de 16 de julho de $1992^{6}$, em seu Capítulo II, intitulado "Jurisdição", elenca - no art. 5\%, I a VI, c/c o art. $6^{\circ}$ - as pessoas sujeitas à tomada e à prestação de contas. Nos termos do art. $7^{\circ}$ da aludida Lei, tais contas "serão anualmente submetidas a julgamento do Tribunal, sob forma de tomada ou prestação de contas, organizadas de acordo com normas estabelecidas em instrução normativa". A seu turno, o art. $9^{\circ}$ da mesma Lei $^{7}$ discrimina os documentos integrantes da tomada ou da prestação de contas, entre os quais se encontra o "relatório de gestão".

Com fundamento nos mencionados arts. $7^{\circ}$ e $9^{\circ}$ da Lei $n^{\circ} 8.443$, de 1992, a Instrução Normativa-TCU $n^{\circ} 63$, de $1^{\circ}$ de setembro de $2010^{8}$, estabelece, em seu art. $3^{\circ}$, que os relatórios de gestão devem ser apresentados anualmente ao Tribunal por parte dos responsáveis pelas unidades jurisdicionadas relacionadas em decisão normativa, que lhes fixará a forma, conteúdo e prazo.

\footnotetext{
${ }^{5}$ O parágrafo único do art. 70 da CF teve sua redação alterada pela Emenda Constitucional no 19 , de 1998. A redação original previa: "Prestará contas qualquer pessoa física ou entidade pública que utilize, arrecade, guarde, gerencie ou administre dinheiros, bens e valores públicos ou pelos quais a União responda, ou que, em nome desta, assuma obrigações de natureza pecuniária”. Houve significativa ampliação, portanto, no grupo de destinatários do comando constitucional em vigor, que passou a abarcar também as pessoas jurídicas de natureza privada, o que possui ampla aplicabilidade no caso do repasse de recursos públicos a entidades privadas mediante convênio ou instrumentos congêneres.

${ }^{6}$ Lei Orgânica do TCU

${ }^{7}$ De acordo com o art. $9^{\circ}$ da Lei $n^{\circ}$ 8.443, de 1992, integrarão a tomada ou prestação de contas os seguintes elementos: I - relatório de gestão; II - relatório do tomador de contas, quando couber; III - relatório e certificado de auditoria, com o parecer do dirigente do órgão de controle interno, que consignará qualquer irregularidade ou ilegalidade constatada, indicando as medidas adotadas para corrigir as faltas encontradas; IV - pronunciamento do Ministro de Estado supervisor da área ou da autoridade de nível hierárquico equivalente.

${ }^{8}$ A IN TCU n ${ }^{\circ}$ 63, de 2010, estabelece normas de organização e de apresentação dos relatórios de gestão e das peças complementares que constituirão os processos de contas da administração pública federal. Tal ato normativo prevê a obrigatoriedade de envio ao Tribunal do relatório de gestão em meio informatizado.
} 
Nesse sentido, o TCU divulga, ao final de cada exercício, por meio de decisão normativa, as unidades jurisdicionadas cujos responsáveis devem apresentar o relatório de gestão referente ao exercício seguinte ${ }^{9}$. São precisamente tais responsáveis que terão suas contas julgadas anualmente pelo TCU, seja sob a forma de tomada ou de prestação de $\operatorname{contas}^{10}$.

Sem prejuízo do julgamento de contas anuais, nos termos do art. $8^{\circ}$ da Lei $\mathrm{n}^{\circ}$ 8.443, de 1992, a função judicante do TCU também pode ser exercida a partir da instauração de tomada de contas especial ${ }^{11}$, diante: da omissão no dever de prestar contas; da nãocomprovação da aplicação dos recursos federais repassados a Estados, Distrito Federal ou Municípios mediante convênio ou instrumento congênere; da ocorrência de desfalque ou desvio de dinheiros, bens ou valores públicos; ou da prática de ato de gestão ilegal, ilegítimo ou antieconômico de que resulte dano ao Erário Público.

\subsection{Processos de contas}

No que se refere aos tipos de contas que serão objeto de análise por ocasião do julgamento de contas, na primeira parte do supratranscrito inciso II ("julgar as contas dos administradores e demais responsáveis”), a CF refere-se às contas ordinárias, prestadas anualmente pelos respectivos responsáveis, tendo por objeto atos de gestão. Já na segunda parte do mesmo inciso II ("e as contas daqueles que derem causa a perda, extravio ou outra irregularidade de que resulte prejuízo ao erário público"), a Constituição se refere às chamadas contas especiais, que têm por objeto a ocorrência de dano, perda, extravio ou outra irregularidade (JACOBY FERNANDES, 2008; FURTADO, 2007) ${ }^{12}$.

Para a adequada compreensão da atividade de exame e julgamento de contas, fazse oportuno abordar as formas pelas quais as contas dos responsáveis por recursos públicos

9 A Decisão Normativa-TCU n ${ }^{\circ} 108$, de 24 de novembro de 2010, estabelece as unidades jurisdicionadas cujos responsáveis devem apresentar o relatório de gestão referente ao exercício de 2011, a serem entregues no exercício de 2012, especificando a organização, a forma, os conteúdos e os prazos de apresentação. Sobre tais aspectos, a Portaria-TCU n $^{\circ} 123$, de 12 de maio de 2011, fornece orientações às unidades jurisdicionadas ao Tribunal quanto ao preenchimento dos conteúdos dos relatórios de gestão.

10 Nos termos do art. 204 do RITCU, o Tribunal julgará as contas anuais até o término do exercício financeiro seguinte àquele em que lhe tiverem sido apresentadas.

11 A IN TCU n ${ }^{\circ} 56$, de 5 de dezembro de 2007, dispõe sobre a instauração e a organização de processo de tomada de contas especial.

12 Além das contas de gestão (art. 71, II, da Constituição Federal), Furtado (2007) inclui, entre as contas anuais ou ordinárias, as chamadas contas de governo (art. 71, I, da Constituição Federal), prestadas anualmente pelo Chefe do Poder Executivo e apreciadas pelo Congresso Nacional. Diferentemente das contas de gestão, as contas de governo não são julgadas pelo TCU, que sobre elas emite parecer prévio para posterior julgamento de mérito pelo Congresso, no exercício da competência prevista no art. 49, IX, da Carta Constitucional. 
são submetidas anualmente à apreciação dos Tribunais de Contas, ou seja, os instrumentos processuais mediante os quais são apreciadas as chamadas contas anuais ou ordinárias. Também se faz mister abordar o tipo de processo por meio do qual são apreciadas as chamadas contas especiais.

\subsubsection{Tomada e prestação de contas}

No que se refere às contas ordinárias, no âmbito federal, conforme o art. $7^{\circ}$ da Lei $\mathrm{n}^{\mathrm{o}}$ 8.443, de 1992, são elas apreciadas pelo TCU por meio de processos de tomada de contas ou de prestação de $\operatorname{contas}^{13}$, que devem ser organizados de acordo com normas estabelecidas em instrução normativa ${ }^{14}$.

Segundo Jacoby Fernandes (2008), a tomada de contas e a prestação de contas nada mais são que um conjunto de demonstrativos contábeis e gerenciais elaborados pelo órgão de contabilidade com a participação do controle interno e do gestor ou gestores responsáveis.

Interessante questão levantada pelo autor diz respeito à hipótese em que uma eventual irregularidade ocorra em níveis hierarquicamente inferiores, considerando que só os dirigentes máximos dos órgãos estão submetidos ao dever de prestar contas, conforme os atos normativos em vigor que operacionalizam tal obrigação. Segundo o autor, o dirigente máximo do órgão ou entidade apenas deixaria de responder caso comprovasse a adoção de providências necessárias e suficientes para coibir a irregularidade e recompor o erário lesado, a exemplo da instauração de processo de tomada de contas especial, objeto do item 1.2.2 do presente trabalho, fazendo referência a tais providências no relatório de suas contas anuais.

Destarte, ainda segundo o mesmo autor, é possível o julgamento individualizado das contas prestadas por determinado órgão, com a prolação de decisões diferentes para cada um dos gestores ${ }^{15}$, segundo a participação de cada agente público na composição final da gestão, ou seja, há a possibilidade do destaque, mesmo em relação a quem não é dirigente, devendo para isso, em processo de contas anuais, ser relacionadas as tomadas de contas especiais instauradas no exercício ou mantidas sobrestadas ou em apuração no ano. Assim, as

13 O Manual de Instrução de Processos de Tomada e Prestação de Contas, aprovado pela Portaria-TCU n ${ }^{\circ} 105$, de 23 de março de 2004, define a prestação de contas como o "processo com as contas dos administradores e responsáveis por órgãos da administração indireta [...]" e conceitua a tomada de contas como o "processo com as contas dos administradores e responsáveis das unidades da administração direta dos poderes da União, a serem submetidas a julgamento pelo Tribunal” (grifos nossos).

14 Trata-se da já mencionada IN TCU nº 63, de 2010.

15 Importante consignar que tal possibilidade é corolário do próprio caráter pessoal das contas de cada gestor. 
condutas individualizadas podem ser objeto de apurações, em separado, em processo de tomada de contas especial, independentemente das contas anuais.

Até mesmo o Chefe do Poder Executivo, caso desça de seu pedestal para assumir a condição de simples gestor, passa a responder como tal, ficando sujeito ao julgamento nas mesmas condições do agente cuja função eventualmente avocou (JACOBY FERNANDES, 2008).

\subsubsection{Tomada de contas especial}

As chamadas contas especiais são aquelas apreciadas pelos Tribunais de Contas em virtude da omissão no dever de prestar contas, da não-comprovação da aplicação dos recursos repassados pelo ente federado, da ocorrência de desfalque ou desvio de dinheiros, bens ou valores públicos ou, ainda, da prática de qualquer ato ilegal, ilegítimo ou antieconômico de que resulte dano ao erário.

Nos termos do art. $8^{\circ}$ da Lei $n^{\circ}$ 8.443, de 1992, diante de tais hipóteses, a autoridade administrativa competente, sob pena de responsabilidade solidária, deverá imediatamente adotar providências com vistas à instauração de processo de tomada de contas especial, para apuração dos fatos, identificação dos responsáveis e quantificação do dano.

De acordo com o art. $3^{\circ}$, caput, da IN TCU n ${ }^{\circ} 56$, de 2007, a tomada de contas especial é um processo devidamente formalizado, com rito próprio, para apurar responsabilidade por ocorrência de dano à administração pública federal e obtenção do respectivo ressarcimento.

Ainda de acordo com o art. $3^{\circ}$ e seus parágrafos da IN TCU no 56 , de 2007, a tomada de contas especial só deve ser instaurada pela autoridade administrativa federal após esgotadas as providências administrativas internas sem obtenção do ressarcimento pretendido, podendo o TCU determinar a instauração de tomada de contas especial, a qualquer tempo, independentemente das medidas administrativas adotadas.

Pode-se dizer que a tomada de contas especial segue um procedimento que se desenvolve em duas fases: interna e externa. Na interna, o órgão jurisdicionado em que ocorreu a omissão, a irregularidade ou o dano instaura uma comissão com poderes investigatórios, visando quantificar o dano, levantando os indícios de autoria ou, em se tratando de omissão ou irregularidade, tomando as contas e verificando indícios de reprovabilidade da conduta do agente. Assim, diante de dano causado ao erário, decorrente de ato ilegal, ilegítimo ou antieconômico, a autoridade competente deve buscar o ressarcimento 
por atos próprios, devendo instaurar a comissão para proceder à tomada de contas especial, uma vez esgotadas as possibilidades de recomposição do dano ou o prazo definido nas normas dos Tribunais de Contas. Igual procedimento cabe à autoridade repassadora de recursos diante da omissão no dever de prestar contas (JACOBY FERNANDES, 2008).

Na segunda fase, a externa, após o encerramento das apurações pela comissão de tomada de contas especial, os autos são remetidos ao Tribunal de Contas competente. Uma vez assegurados o contraditório e a ampla defesa, a Corte julga as contas (JACOBY FERNANDES, 2008).

Segundo Zymler (2009), seja a tomada de contas especial instaurada pela autoridade competente, seja instaurada pelo TCU, o Tribunal emitirá juízo de mérito sobre tais contas, de forma similar ao que ocorre no exame das contas anuais, havendo em todos os processos de contas ampla aplicabilidade dos princípios que garantem o due process of law.

\subsection{Classificação das decisões}

Nos termos do art. 10 e respectivos parágrafos da Lei no 8.443, de 1992, c/c o art. 201 e seus $\S \S$ do Regimento Interno do Tribunal de Contas da União (RITCU) ${ }^{16}$, a decisão em processos de contas pode ser:

- Preliminar: é a decisão pela qual o Relator ou o Tribunal, antes de pronunciarse quanto ao mérito das contas, resolve sobrestar o julgamento, ordenar a citação ou a audiência dos responsáveis ou, ainda, determinar outras diligências necessárias ao saneamento do processo;

- Definitiva: é a decisão pela qual o Tribunal julga o mérito das contas, considerando-as regulares, regulares com ressalva, ou irregulares; ou

- Terminativa: é a decisão pela qual o Tribunal ordena o trancamento das contas que forem consideradas iliquidáveis ou determina seu arquivamento, pela ausência de pressupostos de constituição e de desenvolvimento válido e regular do processo, ou ainda por racionalização administrativa e economia processual.

Segundo Jacoby Fernandes (2008), e conforme os arts. 16 a 19 da Lei $n^{\circ}$ 8.443, de 1992, a decisão definitiva, que julga o mérito das contas, tanto ordinárias (anuais) quanto especiais, pode considerá-las, conforme o caso, como: regulares, quando não houver prejuízo;

\footnotetext{
${ }^{16}$ Aprovado pela Resolução-TCU n ${ }^{\circ}$ 155, de 4 de dezembro de 2002.
} 
regulares com ressalva, quando, não havendo prejuízo, ficar evidenciada outra irregularidade; irregulares, quando houver dano.

Quando julga as contas como regulares, o Tribunal de Contas dá quitação plena ao responsável. Se as contas forem julgadas regulares com ressalva, o Tribunal dará quitação ao responsável e lhe determinará, ou a quem lhe haja sucedido, a adoção de medidas necessárias à correção das impropriedades ou faltas identificadas, de modo a prevenir a ocorrência de outras semelhantes. Quando as contas são julgadas como irregulares, havendo débito, o Tribunal condenará o responsável ao pagamento da dívida, atualizada monetariamente, e acrescida dos juros de mora devidos, podendo, ainda, aplicar-lhe a multa prevista no art. 57 da Lei $\mathrm{n}^{\circ} 8.443$, de 1992. Caso não haja débito, mas tenha sido comprovada qualquer das ocorrências que justifiquem o julgamento das contas como irregulares, o Tribunal aplicará ao responsável a multa prevista no inciso I do art. 58 da Lei no 8.443, de 1992 (FURTADO, 2007).

De acordo com o art. 209 do RITCU, o Tribunal julgará as contas irregulares diante de qualquer das seguintes ocorrências: omissão no dever de prestar contas; prática de ato de gestão ilegal, ilegítimo ou antieconômico, ou infração a norma legal ou regulamentar de natureza contábil, financeira, orçamentária, operacional ou patrimonial; dano ao erário decorrente de ato de gestão ilegítimo ou antieconômico; desfalque ou desvio de dinheiros, bens ou valores públicos.

\subsection{Execução administrativa das decisões condenatórias}

No presente trabalho, convencionou-se chamar "decisões condenatórias" aquelas em que o Tribunal de Contas julga as contas do responsável como irregulares, imputando-lhe débito ou cominando-lhe multa. Segundo Costa Júnior (2001), quando o Tribunal de Contas imputa débito ao gestor ou lhe aplica multa, com base no art. 71, II e VIII, da CF, está proferindo uma decisão de caráter eminentemente condenatório.

Neste ponto, impende destacar que o débito e a multa possuem natureza jurídica distinta. Segundo Chaves (2009), nada obstante o fato de serem ambos expressos em pecúnia, o débito possui natureza de responsabilização civil pelo prejuízo causado ao patrimônio e a multa possui natureza de sanção. ${ }^{17}$

17 Em função das naturezas jurídicas distintas, as ações visando ao ressarcimento de débitos não prescrevem, mas aquelas envolvendo multas encontram-se sujeitas à prescrição. Além disso, a dívida advinda da 
O débito é a lesão quantificada em termos monetários, cuja imputação visa a recompor o patrimônio lesado, e seu recolhimento aos cofres de quem sofreu a lesão faz com que o patrimônio retorne ao mesmo estado que possuía antes da lesão. Já a multa é penalidade de natureza pecuniária que deve ser recolhida ao patrimônio do ente federado ao qual pertença o Tribunal de Contas sancionador (CHAVES, 2009).

Para Zymler (2009), os processos convencionais de tomadas e prestações de contas não têm, via de regra, caráter contencioso, ou seja, estabelece-se relação processual entre a Administração e o administrado, pela qual este deve prestar contas de sua gestão. Em geral, portanto, a finalidade dos processos de contas seria a promulgação de acórdão pelo Tribunal de Contas comprovando a regular aplicação dos recursos públicos pelo responsável, estando a atuação de ambos voltada à consecução de tal fim, sem que haja conflito de interesses, mas sim conjugação de esforços.

Ainda de acordo com o referido autor, no entanto, quando a regularidade das contas é questionada, transmuta-se a natureza do processo, com o surgimento de conflito de interesses entre o administrado e a Administração, estabelecendo-se processo de natureza contenciosa, informado pelo princípio do contraditório e da ampla defesa. ${ }^{18}$

Nos termos do art. 12 da Lei $n^{\circ}$ 8.443, de 1992, verificada irregularidade nas contas, o Relator ou o Tribunal definirá a responsabilidade individual ou solidária pelo ato de gestão inquinado; se houver débito, ordenará a citação do responsável para apresentar defesa ou recolher a quantia devida; se não houver débito, determinará a audiência do responsável para apresentar razões de justificativa ${ }^{19}$. Rejeitadas estas, o responsável será notificado da eventual aplicação da penalidade de multa.

Havendo débito e tendo sido citado o responsável, de acordo com o $\S 1^{\circ}$ do art. 12 da Lei $n^{\circ} 8.443 / 1992$ c/c os $\S \S 2^{\circ}$ e $3^{\circ}$ do art. 202 do RITCU, a rejeição de sua defesa implicará notificação para o recolhimento da importância devida em novo e improrrogável prazo, caso tenha sido constatada a boa-fé e não haja outras irregularidades em suas contas ${ }^{20}$.

imputação de débito transmite-se por herança até o valor do patrimônio transferido, enquanto aquela proveniente da cominação de multa não se transmite aos sucessores.

18 Oportuno mencionar que, no processo de contas, o Tribunal exerce um controle subjetivo sobre a conduta do agente, diferentemente do que se dá no exame de atos e contratos, em que ocorre um controle eminentemente objetivo, ou seja, de verificação da conformidade do ato com o ordenamento jurídico, sem que haja um caráter propriamente contencioso.

19 De acordo com o art. 202, II e III, do RITCU, o prazo para a apresentação de defesa (no caso de débito) ou para a apresentação de razões de justificativa (quando não houver débito) é de quinze dias.

20 Nos termos do $\S 4^{\circ}$ do art. 202 do RITCU, a liquidação tempestiva do débito atualizado monetariamente saneará o processo e o Tribunal julgará as contas regulares com ressalva, dando quitação ao responsável. Zymler (2009) alerta para o fato de que, diferentemente do que ocorre no Direito Privado, em que a presunção de boa-fé predomina e deve ser afastada por quem alega o contrário, no campo do Direito 
Contudo, o não-reconhecimento da boa-fé ou a existência de outras irregularidades implicará, desde logo, o julgamento definitivo pela irregularidade das contas, conforme o art. 202, § $6^{\circ}$, do RITCU.

Publicada a decisão condenatória definitiva no Diário Oficial da União, esta constituirá obrigação de o responsável provar, perante o Tribunal, no prazo de quinze dias, o pagamento da quantia correspondente ao débito que lhe tiver sido imputado ou da multa que lhe houver sido cominada ${ }^{21}$, conforme o art. 214, III, "a”, do RITCU. Nos termos do art. 219 do RITCU, expirado o prazo de quinze dias contados da publicação, o TCU poderá determinar o desconto integral ou parcelado da dívida nos vencimentos, subsídio, salário ou proventos do responsável. Alternativamente, o Tribunal poderá autorizar a cobrança judicial da dívida, por intermédio do MP/TCU. ${ }^{22}$

Neste tocante, o acórdão condenatório constitui título executivo para a cobrança judicial da dívida, caso esta não seja paga no prazo pelo responsável e caso não tenha sido autorizado pelo Tribunal, em qualquer fase do processo, o pagamento parcelado da importância em até vinte e quatro parcelas, conforme previsto no art. 217 do Regimento Interno.

\subsection{Princípios relevantes aos julgamentos de contas}

Além dos princípios expressamente previstos no caput do art. 37 da $\mathrm{CF}^{23}$ e de outros como o princípio do impulso oficial ou da oficialidade, pelo qual compete à Administração, uma vez instaurada a relação processual, mover o procedimento de fase em fase, visando ao trâmite contínuo do processo, até se exaurir o exercício da função jurisdicional (CINTRA, GRINOVER E DINAMARCO, 2006; ZYMLER, 2009), alguns princípios merecem especial realce no que se refere, em geral, aos processos administrativos e, em particular, aos processos de contas. Trata-se dos princípios do contraditório e da ampla

Financeiro, de caráter eminentemente público, a ausência de prestação de contas faz surgir contra o gestor de recursos públicos presunção de ilicitude, que pode ser elidida pela apresentação de sólidos argumentos de defesa.

21 O não-pagamento no referido prazo implicará a inscrição do nome do responsável no Cadastro Informativo de créditos não quitados do setor público federal (Cadin), conforme previsto no inciso III do art. 219 do RITCU.

22 Cabe registrar a possibilidade de haver interposição de recursos perante o Tribunal com efeito suspensivo (item 1.5.1).

23 “Art. 37. A administração pública direta e indireta de qualquer dos Poderes da União, dos Estados, do Distrito Federal e dos Municípios obedecerá aos princípios de legalidade, impessoalidade, moralidade, publicidade e eficiência e, também, ao seguinte:" (grifo nosso). 
defesa, do princípio da verdade material, do princípio do formalismo moderado, e do princípio da racionalização administrativa e economia processual.

\subsubsection{Princípios do contraditório e da ampla defesa}

Os princípios do contraditório e da ampla defesa encontram-se expressamente previstos no art. $5^{\circ}, \mathrm{LV}$, da $\mathrm{CF}$, segundo o qual "aos litigantes, em processo judicial ou administrativo, e aos acusados em geral são assegurados o contraditório e a ampla defesa, com os meios e recursos a ela inerentes" (grifo nosso). Aludido princípio, portanto, tem aplicabilidade não só aos processos judiciais, mas também aos processos administrativos.

Segundo Cintra, Grinover e Dinamarco (2006), decorre de tal princípio a necessidade de que se dê ciência às partes dos atos praticados no processo, pois somente a partir de tal ciência poder-se-á efetivar o contraditório. Em síntese, este é constituído por dois elementos: a informação e a reação.

Na mesma esteira, Zymler (2009), ao mesmo tempo em que reconhece ser difícil precisar os limites existentes entre o princípio do contraditório e o da ampla defesa, entende que o contraditório abrange a faculdade de manifestação do próprio ponto de vista ou de argumentos próprios ante fatos, documentos ou pontos de vista apresentados por outrem, sendo corolário do princípio da igualdade, porquanto propicia oportunidades idênticas aos administrados para expor seus pontos de vista, produzir provas, apresentar alegações etc. Nesse sentido, o contraditório desdobra-se em: direito à informação geral; direito de ser ouvido; e necessidade de motivação dos atos administrativos.

Particularmente no que toca ao direito de ser ouvido, o autor entende que, quando a Administração exerce seu poder de polícia, aplicando multa ao infrator de determinado regulamento, o processo administrativo se forma com a promulgação do ato punitivo, que será combatido por meio dos recursos administrativos cabíveis.

Segundo Furtado (2007), o contraditório e a ampla defesa devem ser obrigatoriamente assegurados, como consectários do princípio maior do devido processo legal, sendo a observância de tais princípios decorrência do próprio texto constitucional, nada obstante a legislação, inclusive a Lei $n^{\circ} 9.784$, de 29 de janeiro de $1999^{24}$, ratificar sua observância. Para o autor, consequências diretas dos princípios da ampla defesa e do

\footnotetext{
24 Regula o processo administrativo no âmbito da Administração Pública Federal.
} 
contraditório são a possibilidade de o interessado ter acesso às informações constantes dos autos do processo de modo a poder contraditá-las e delas se defender.

Importante destacar, como decorrência dos princípios do contraditório e da ampla defesa nos processos apreciados pelos Tribunais de Contas, a possibilidade da interposição de recursos. Assim é que, conforme o art. 277 do RITCU, existem cinco espécies recursais na Corte de Contas Federal: recurso de reconsideração; pedido de reexame; embargos de declaração; recurso de revisão; e agravo.

Segundo Zymler (2009), são recursos típicos previstos na Lei Orgânica do TCU (Lei no 8.443, de 1992 - LOTCU) o recurso de reconsideração (art. 33) e o pedido de reexame (art. 48), dirigidos aos colegiados que prolataram a decisão recorrida. Tais recursos têm efeito suspensivo e podem ser interpostos no prazo de quinze dias, contados na forma do art. 30, sendo o primeiro aplicável a processos de contas e o segundo a processos de fiscalização.

Importante registrar, no que toca ao recurso de reconsideração, que se este versar sobre item específico do acórdão, os demais itens não recorridos não sofrem o efeito suspensivo, caso em que deverá ser constituído processo apartado para prosseguimento da execução da decisão (art. 285, § $1^{\circ}$, do RITCU).

Em processos de contas, além do suprarreferido pedido de reconsideração, são aplicáveis, conforme o art. 32 da LOTCU, os embargos de declaração e o recurso de revisão. Aqueles prestam-se a corrigir obscuridade, omissão ou contradição da decisão recorrida, possuindo efeito suspensivo, ao passo que este é interposto contra decisão definitiva do Plenário, no prazo de cinco anos, sem efeito suspensivo, possuindo natureza similar à da ação rescisória do Direito Processual Civil.

Em que pese o art. 278 do RITCU prever o exame de admissibilidade pelo Relator do recurso, inclusive no que toca à observância dos prazos recursais, Zymler destaca que os prazos de interposição, nos processos administrativos, não devem ser interpretados como peremptórios. Além disso, tem plena aplicabilidade em tais processos o princípio da fungibilidade recursal, como corolário dos princípios da verdade material e do formalismo moderado (itens 1.5.2 e 1.5.3), para adaptar as peças recursais recebidas ao correto traçado legal.

\subsubsection{Princípio da verdade material}

Cintra, Grinover e Dinamarco (2006) diferenciam a verdade formal, que corresponde ao que resulta ser verdadeiro em face das provas contidas nos autos, da verdade 
real ou material. Enquanto aquela, em princípio, satisfaz o julgador no processo civil, esta se revela obrigatória no processo penal como fundamento da sentença.

À semelhança do que ocorre no processo penal, o processo administrativo de contas também se rege pelo princípio da verdade material. Assim, embora o não-atendimento à citação ou à audiência implique a consideração do responsável como revel pelo Tribunal, "para todos os efeitos", dando-se prosseguimento ao processo (art. 202, § $8^{\circ}$, do RITCU), Zymler (2009), por força de tal princípio, assevera que a presunção de veracidade dos fatos afirmados pelo autor, prevista pelo art. 319 do CPC como efeito da revelia, não se aplica a litígios que versem sobre direitos indisponíveis, nos termos do disposto no art. 320, II, do CPC, razão pela qual referida presunção não se aplica ao processo de contas, em que se tutelam interesses públicos indisponíveis ${ }^{25}$.

Ainda segundo Zymler (2009), o art. 322 do CPC arrola duas outras consequências processuais da revelia: os prazos correrão, independentemente de intimação, contra o revel que não tenha patrono constituído nos autos e, apesar da possibilidade de o revel intervir no processo em qualquer fase, recebê-lo-á no estado em que se encontre.

Em relação a esta última consequência, o autor afirma que, embora nos processos judiciais os atos preclusos não possam ser repetidos, devendo o revel participar da marcha processual e assumir o ônus de sua conduta, na esfera administrativa o efeito decorrente da preclusão deve ser necessariamente mitigado, em função da aplicabilidade dos princípios da verdade material e do formalismo moderado. Desse modo, por exemplo, a apresentação extemporânea de novos elementos aos autos deverá, em regra, ser tolerada, sendo descabido o apelo à figura da preclusão como óbice à ampla participação no processo.

Segundo Furtado (2007), nos processos administrativos, diversamente do que ocorre com os processos judiciais, especialmente no âmbito do processo civil, os responsáveis pela condução dos autos não se devem ater exclusivamente às informações constantes do processo para a formação das suas convicções e para a construção das decisões a serem proferidas, nada obstante se espere que a verdade formal, aquela que se extrai exclusivamente dos autos, corresponda à realidade dos fatos e à correta aplicação do direito, ou seja, espera-se que a verdade formal esteja em harmonia com a verdade material. Eventual descompasso entre uma e outra deve ser decidido com base na verdade material.

Zymler (2009), na mesma esteira, afirma que, ao contrário dos processos jurisdicionais, em que o princípio da verdade dos autos predomina, o processo administrativo

25 Em que pese isto, a ausência de alegações de defesa ou de razões de justificativa prejudicam sobremaneira a posição do interessado no processo de contas. 
deve ser informado pelo princípio da verdade material, pelo simples fato de que os direitos em jogo são sempre de ordem pública e a atividade processual das partes, no sentido de produzir provas, é meramente subsidiária, sendo lícito à Administração, na busca da verdade, promover a produção de provas, bem como inaplicável a presunção de veracidade de fatos não contestados por outro interessado no processo.

\subsubsection{Princípio do formalismo moderado}

O princípio do formalismo moderado é corolário do princípio da verdade material, pois a busca da verdade muitas vezes exige a desconsideração dos aspectos formais ligados à produção dos atos processuais, a exemplo dos prazos, que não têm, via de regra, caráter peremptório. Assim é que se busca evitar que as formas sejam um fim em si mesmo (ZYMLER, 2009).

Segundo Furtado (2007), o processo deve ser o instrumento para a realização dos fins estatais e para assegurar a observância dos princípios garantidores dos direitos e garantias fundamentais. Nesse sentido, a possibilidade de serem superadas falhas processuais que não tenham causado dano a terceiros ou de serem conhecidos recursos administrativos intempestivos em razão da relevância da matéria tratada são exemplos de aplicação, aos processos administrativos, do princípio do formalismo moderado.

1.5.4 Princípio da racionalização administrativa e economia processual

O princípio da racionalização administrativa e economia processual encontra-se insculpido no art. 93 da LOTCU, segundo o qual:

Art. 93. A título de racionalização administrativa e economia processual, e com o objetivo de evitar que o custo da cobrança seja superior ao valor do ressarcimento, o Tribunal poderá determinar, desde logo, o arquivamento do processo, sem cancelamento do débito, a cujo pagamento continuará obrigado o devedor, para que lhe possa ser dada quitação.

O supratranscrito dispositivo legal é praticamente reproduzido na íntegra pelo art. 213 do RITCU, o qual prevê que o Tribunal - a título de racionalização administrativa e economia processual, e para evitar que o custo da cobrança seja superior ao valor do ressarcimento - poderá determinar, desde logo, o arquivamento do processo, nos termos de 
ato normativo. Em tal hipótese, o TCU profere decisão terminativa, consoante o $\S 3^{\circ}$ do art. 201 de seu Regimento Interno.

A partir do disposto no $\S 2^{\circ}$ do art. $8^{\circ}$ da Lei $n^{\circ} 8.443$, de 1992, o RITCU estabelece, em seu art. 199, que a tomada de contas especial será, desde logo, encaminhada ao Tribunal para julgamento, se o dano ao erário for de valor igual ou superior à quantia fixada em cada ano civil, até a última sessão ordinária do Plenário, para vigorar no exercício subsequente.

Nos termos do $\S 2^{\circ}$ do mesmo artigo, sendo majorado tal limite, as tomadas de contas especiais de exercícios anteriores em tramitação no Tribunal cujo dano ao erário seja inferior ao novo valor fixado poderão ser arquivadas, sem cancelamento do débito, desde que não tenha sido ainda efetivada a citação dos responsáveis, já que esta inaugura a litigiosidade do processo, dando azo à necessária observância dos princípios do contraditório e da ampla defesa.

A IN-TCU no 56 , de 2007, estabelece, em seus arts. $5^{\circ}$ e 11 , que a tomada de contas especial somente deve ser instaurada e encaminhada ao Tribunal quando o valor do dano, atualizado monetariamente, for igual ou superior à quantia de $\mathrm{R} \$ 23.000,00$.

Considerando que um dos vetores da atuação do controle externo é o princípio da economicidade, Jacoby Fernandes (2008) entende que os Tribunais de Contas têm o dever moral de observar tal princípio em seus procedimentos, sendo uma das formas mais inteligentes de operacionalizá-lo a definição da competência em razão do valor para atuar no processo (valor de alçada).

Segundo Pereira e Souza (apud JACOBY FERNANDES, 2008, p. 494), "alçada é a quantia além da qual não se pode julgar”. Nesse sentido, o valor de alçada no TCU, atualmente, é de $\mathrm{R} \$ 23.000,00$, considerado o limite abaixo do qual o custo da cobrança não justifica o valor a ser eventualmente recuperado em tomadas de contas especiais. 


\section{NATUREZA JURÍDICA, REVISIBILIDADE JUDICIAL E EFICÁCIA DAS DECISÕES CONDENATÓRIAS}

Conforme mencionado no capítulo anterior, o processo de contas não possui caráter contencioso até que a regularidade das contas venha eventualmente a ser questionada. A partir deste momento, a natureza do processo transmuta-se, tendo em vista o surgimento de um conflito de interesses entre Administração e administrado, pelo qual se estabelece um processo de caráter contencioso, que observará o devido processo legal (ZYMLER, 2009).

Uma vez garantidos o contraditório e a ampla defesa, inclusive por meio da interposição de eventuais recursos, a decisão definitiva do Tribunal de Contas - na forma de acórdão - que conclua pela irregularidade das contas imputará um débito ao responsável e/ou cominar-lhe-á multa. Convencionou-se, no presente trabalho, denominar tais acórdãos de “decisões condenatórias".

No presente capítulo, abordar-se-á a intrincada e antiga questão atinente à natureza jurídica das decisões condenatórias para, a partir de tal abordagem, perquirirem-se os limites aplicáveis a sua revisibilidade judicial e delimitar-se sua eficácia.

\subsection{Natureza jurídica das decisões condenatórias}

Questão assaz relevante diz respeito à natureza jurídica das decisões condenatórias proferidas pelos Tribunais de Contas, havendo autores que entendem serem estas decorrentes de autêntica função jurisdicional e outros que pretendem reservar o exercício de tal função exclusivamente em favor do Poder Judiciário.

Conforme se verá adiante, a questão não é recente, havendo autores que sobre ela se debruçaram desde a primeira metade do século $\mathrm{XX}^{26}$. Em que pese isto, a reflexão que ora se propõe não se afigura estéril. Ao contrário, a exata definição da natureza jurídica das decisões condenatórias possui implicações diretas sobre os limites aplicáveis à revisibilidade judicial de tais decisões e à eficácia dos títulos condenatórios.

26 Em verdade, tal questão surge por ocasião da própria criação do Tribunal de Contas no Brasil. Rui Barbosa, na exposição de motivos do Decreto $\mathrm{n}^{\circ}$ 966-A, de 7 de novembro de 1890, define o órgão como corpo de magistratura intermediária à administração e à legislatura, não pertencendo, portanto, nem a uma, nem a outra, mas colocado em posição autônoma, com atribuições de revisão e julgamento, cercado de garantias contra quaisquer ameaças. 


\subsubsection{O sistema da unicidade da jurisdição}

A jurisdição pode ser definida como poder, função e atividade. Como poder, jurisdição é a manifestação do poder estatal, conceituado como capacidade de decidir imperativamente e impor decisões. Como função, expressa o encargo que têm os órgãos estatais de promover a pacificação de conflitos interindividuais, mediante a realização do direito justo e através do processo. Como atividade, é o complexo de atos do juiz no processo, exercendo o poder e cumprindo a função que a lei lhe comete. O poder, a função e a atividade somente transparecem legitimamente através do processo devidamente estruturado, ou seja, por meio do devido processo legal (CINTRA, GRINOVER e DINAMARCO, 2006).

Ainda segundo Cintra, Grinover e Dinamarco (2006), a jurisdição, como expressão do poder estatal soberano, a rigor não comporta divisões, pois falar em diversas jurisdições em um mesmo Estado significaria afirmar a existência de uma pluralidade de soberanias, o que não faria sentido. Assim, a jurisdição é, em si mesma, tão una e indivisível quanto o próprio poder soberano.

Di Pietro (1996) entende que o sistema da unicidade da jurisdição decorreria do art. 5, XXXV, da CF, segundo o qual "a lei não excluirá da apreciação do Poder Judiciário lesão ou ameaça a direito". A autora entende que, em face deste dispositivo, nenhuma decisão do Tribunal de Contas ou de qualquer outro órgão, seja ele afeto ao Legislativo ou ao Executivo, que cause lesão ou ameaça de lesão pode ser subtraída da apreciação do Poder Judiciário. Nesse sentido, nosso sistema constitucional não teria dado guarida ao sistema de dualidade de jurisdição, originado do direito francês, em que os órgãos do chamado “contencioso administrativo" apreciam as questões em que a Administração Pública seja parte interessada, em caráter definitivo, com a mesma força de coisa julgada de que são dotadas as decisões da Justiça Comum.

Por outro lado, Jacoby Fernandes (1996) afirma parecer uníssono o entendimento de que o Brasil adota o sistema de jurisdição única ou inglês, o que significaria que somente o Poder Judiciário poderia exercer a função jurisdicional. O sistema francês ou do contencioso administrativo, a seu turno, admite que um órgão, não integrante do Judiciário, declare o Direito aplicável ao caso concreto, inibindo a reapreciação do mesmo fato por este Poder. Ainda segundo o autor, os doutrinadores pátrios admitem, também de modo quase absoluto, que não existe sistema puro em nenhum País. 
Jacoby Fernandes (1996) prossegue afirmando que, diante do supratranscrito inciso XXXV do art. $5^{\circ}$ da $\mathrm{CF}$, qualquer diploma infraconstitucional que pretendesse restringir a apreciação de certas demandas pelo Poder Judiciário seria, a toda evidência, inconstitucional, por ofensa à referida norma. Em que pese isto, referido dispositivo tem por destinatário o legislador infraconstitucional, mas não veda que a própria Constituição imponha o exercício da função jurisdicional a outro órgão, não integrante do Poder Judiciário.

Nesse sentido, são exceções ao sistema da unicidade da jurisdição na ordem constitucional brasileira: o julgamento, pelo Congresso Nacional, das contas prestadas pelo Presidente da República (art. 49, IX); o julgamento, pelo Senado Federal, do Presidente e do Vice-Presidente da República nos crimes de responsabilidade, bem como os Ministros de Estado e os Comandantes da Marinha, do Exército e da Aeronáutica nos crimes da mesma natureza conexo com aqueles (art. 52, I); o julgamento dos Ministros do Supremo Tribunal Federal, dos membros do Conselho Nacional de Justiça e do Conselho Nacional do Ministério Público, o Procurador-Geral da República e o Advogado-Geral da União nos crimes de responsabilidade (art. 52, II); e o julgamento de contas pelo TCU (art. 71, II).

Os exemplos acima elencados são casos de exercício da função jurisdicional por órgãos não integrantes do Poder Judiciário, pelo simples fato de que o legislador constituinte, expressamente, deslocou tal competência para órgãos específicos, tendo em vista relevantes razões jurídicas, morais e lógicas (JACOBY FERNANDES, 1996).

\subsubsection{As decisões condenatórias como exercício da jurisdição}

Em que pesem as exceções constitucionalmente estabelecidas ao sistema da unicidade da jurisdição, autores há que se posicionam contrariamente ao reconhecimento da função jurisdicional exercida pelos Tribunais de Contas quando estes julgam contas ${ }^{27}$.

Tais autores entendem, de forma equivocada, que o sistema da unicidade da jurisdição seria absoluto em nosso País - o que já foi refutado no item anterior - e fundamentam seus argumentos, adicionalmente, nos seguintes pontos: $1^{\circ}$ ) o fato de os Tribunais de Contas não pertencerem ao Poder Judiciário; $2^{\circ}$ ) o entendimento de que o

27 Embora até hoje ainda haja tal celeuma, a função jurisdicional exercida pelos Tribunais de Contas já é defendida por seus membros há mais de cinquenta anos. Nesse sentido, em 1959, por ocasião do $1^{\circ}$ Congresso de Tribunais de Contas do Brasil, em São Paulo, foi aprovada a Resolução ${ }^{\circ}$ 02, segundo a qual "Os Tribunais de Contas funcionam como Tribunais de Justiça, no julgamento dos processos de tomada de contas; suas decisões devem ter força operante, em todos os casos sujeitos à sua alçada, sobretudo quando dos seus efeitos resultarem ressarcimento a favor da Fazenda Pública" (COSTA JÚNIOR, 2001). 
julgamento de contas seria uma atividade meramente técnico-contábil; $3^{\circ}$ ) características substanciais da jurisdição (YAMADA, 2005).

No que se refere ao primeiro ponto, Di Pietro (1996) afirma que, embora a Constituição empregue, no inciso II de seu art. 71, o termo "julgar”, o caput do mesmo artigo confere ao Tribunal de Contas a incumbência de auxiliar o Congresso Nacional. A autora afirma que seria inconcebível imaginar-se que o Tribunal de Contas, que auxilia o Legislativo no controle externo, pudesse estar integrado ao Poder Judiciário, lembrando que o art. 92 da Constituição, ao relacionar os órgãos integrantes do Poder Judiciário, não inclui o Tribunal de Contas.

Há, em tal raciocínio, lamentável equívoco. Sem dúvida, a autora está correta quando afirma que os Tribunais de Contas não são órgãos integrantes da estrutura do Poder Judiciário, mas tal fato, por si só, não é capaz de excluir das Cortes de Contas o exercício de sua função jurisdicional. Não se pode confundir a função exercida pelos Tribunais de Contas em sua competência de julgamento de contas com a posição que tais órgãos ocupam em relação aos três Poderes do Estado Brasileiro. Como foi visto no item anterior, a função jurisdicional não é exclusiva do Poder Judiciário, podendo-se inclusive falar em "jurisdição administrativa" (MEIRELLES, 1993 apud BUGARIN, 2004, p. 75).

No que toca ao segundo ponto, Nilo de Castro (1999 apud COSTA JÚNIOR, 2001, p. 77-78) afirma que os Tribunais de Contas não exercem função judicante, pois julga "não as pessoas, apenas exerce julgamento técnico das contas". Costa Júnior (2001) refuta tal entendimento, pois tribunal algum deste mundo está incumbido de julgar os homens por aquilo que são, ou seja, em seu aspecto subjetivo, mas tão-somente de forma objetiva, em virtude dos atos que tenham praticado.

Na mesma esteira, Jacoby Fernandes (2008 apud YAMADA, 2005, p. 42-43) afirma que os Tribunais de Contas, quando julgam contas, definem a responsabilidade do agente, pois a competência constitucionalmente outorgada se refere a julgar as contas dos administradores e demais responsáveis. O autor lembra que é da tradição dos Tribunais de Contas, inclusive no Brasil, a possibilidade inclusive de ordenar a prisão dos responsáveis com alcance julgado em sentença definitiva do Tribunal $^{28}$, possibilidade que só se conforma com a lógica elementar se os julgamentos se fizerem sobre pessoas. Nesse sentido, "nenhum

28 A competência para ordenar a prisão dos responsáveis com alcance julgado em sentença definitiva do Tribunal encontrava-se prevista na antiga Lei Orgânica do TCU (Lei nº 830, de 1949). Tal previsão não subsiste no ordenamento em vigor. 
tribunal ou juiz julga pessoas, mas condutas ou comportamentos humanos. Julgar pessoas, na sua integridade, é competência privativa de Deus".

Ainda segundo Jacoby Fernandes (1996), ao proferir decisão pela irregularidade das contas, a Corte precisa identificar a causa da irregularidade e o agente responsável, não havendo como garantir a ampla defesa e o contraditório sem tais elementos.

No que tange ao terceiro ponto, qual seja, o entendimento de que estaria ausente, no julgamento de contas, características substanciais da jurisdição, há autores que argumentam que a relação processual existente entre o responsável e o Tribunal de Contas é linear, ao contrário da relação jurídica processual clássica, angular e com caráter de substitutividade (COSTA JÚNIOR, 2001).

Das três linhas argumentativas, esta parece ser a menos frágil, mas, de igual sorte, não se sustenta. De fato, nos processos de contas, está ausente a triangularidade clássica da jurisdição, formada por juiz, autor e réu, mas a não-conformidade aos exatos termos do modelo processual clássico não permite que se descarte a função jurisdicional efetivamente exercida pelas Cortes de Contas brasileiras.

Nesse sentido, segundo Costa Júnior (2001), tal particularidade ocorre para se atender às necessidades peculiares da atividade exercida pelos Tribunais de Contas. Assim, "nem tudo aquilo que não se ajusta à moldura da Teoria Geral do Processo deixa de ser atividade jurisdicional apenas por isto". À guisa de exemplo, o autor cita o antigo processo criminal sumário, previsto no art. 531 do Código de Processo Penal, que perdurou no Brasil até 1988 e que era inaugurado por portaria de juiz de direito, bem como o duplo grau obrigatório de jurisdição com modificação da decisão em segunda instância. Tais casos não se amoldam exatamente ao padrão clássico de triangularidade e inércia judiciais, mas nem por isso deixam de ser exemplos concretos de exercício legítimo da jurisdição pelo Estado.

$\mathrm{O}$ autor prossegue afirmando que, enquanto os órgãos integrantes do Poder Judiciário, talvez por julgarem precipuamente conflitos entre particulares, somente estão autorizados a atuar depois que o interessado manifesta a vontade de defender seus direitos por meio da propositura de uma ação - passando-se a partir daí a se impor o princípio da indeclinabilidade da jurisdição -, os Tribunais de Contas também se submetem a este princípio, com a peculiaridade de que o interesse juridicamente tutelado pela atuação destas Cortes não é privado, mas eminentemente público.

Jacoby Fernandes (2008) menciona ainda duas argumentações adicionais daqueles que se negam a reconhecer o exercício da jurisdição pelos Tribunais de Contas. A primeira 
delas é que as decisões dos Tribunais de Contas não constituem expressões da jurisdição porque não são executáveis pelas próprias Cortes (sobre a questão da autoexecutoriedade, ver item 3.5.2). Tal entendimento não merece prosperar, de vez que, raramente, um Tribunal é o executor direto de sua própria decisão, já que esta em geral é executada pelo primeiro grau de jurisdição.

Por sua vez, a segunda argumentação é aquela defendida por Gualazzi (1992 apud JACOBY FERNANDES, 2008, p. 178), segundo a qual as decisões dos Tribunais de Contas poderiam ser classificadas como coisa julgada administrativa. Segundo Jacoby Fernandes (2008), tal tese erra ao incorrer na generalização, pois não diferencia as atividades de apreciar (ex: atos de pessoal para fins de registro, nos termos do art. 71, III, da CF), de fiscalizar (ex: realização de auditorias, conforme art. 71, IV, da CF) e de julgar (art. 71, II, da CF).

Baleeiro (1984 apud BUGARIN, 2004, p. 77) afirma que o modelo de controle orçamentário adotado no Brasil é o jurisdicional, equiparando-o aos modelos francês, italiano e português. O grande tributarista e financista vislumbrava, na configuração institucional dos Tribunais de Contas brasileiros, o conjunto de características típicas do controle jurisdicional de contas no Direito Comparado, quais sejam: “a) órgão colegiado composto de membros sem dependência direta do Parlamento nem do Executivo ${ }^{29}$; b) processo judicial de apreciação das contas; c) subordinação de contabilidade ao Executivo sob fiscalização desse órgão”. Bugarin (2004) sintetiza tal posicionamento na qualificação do Tribunal de Contas, pelo saudoso mestre, como "órgão administrativo, colegiado, com funções jurisdicionais sobre os ordenadores e pagadores de dinheiros públicos, no interesse da própria administração".

Segundo Furtado (2007), as decisões proferidas pelo TCU muito mais se aproximam dos atos judiciais que dos tradicionais atos administrativos, tanto que são asseguradas a seus Ministros as garantias e as prerrogativas próprias dos magistrados (art. 73, $\S 3^{\circ}$, da $\mathrm{CF}$ ). Para o autor, o conceito de jurisdição não é tão estranho às atividades dos Tribunais de Contas quanto supunham alguns "cientistas" do Direito Processual, que negavam a existência do processo administrativo. O TCU, segundo o autor, exerce jurisdição administrativa e, no desempenho dessa tarefa, julga as contas dos gestores públicos, muito embora suas decisões não detenham natureza judicial, pois os Tribunais de Contas não

29 Este é exatamente o caso do TCU, cujos membros não são subordinados ao Congresso Nacional, carecendo este de competência para rever as decisões proferidas pelo Tribunal. O TCU é órgão autônomo que não pertence nem é subordinado a nenhum dos três Poderes clássicos. Nos termos da teoria do policentrismo institucional, perfilhada por Canotilho (1991 apud ZYMLER E LA ROCQUE ALMEIDA, 2008, p. 136), este fenômeno acarreta a distribuição de funções políticas para vários órgãos e entidades públicos, os quais passam a atuar como centros de poder. 
integram o Poder Judiciário e suas decisões regem-se por normas de Direito Administrativo e Constitucional e não pelo Direito Processual.

Assim sendo, as decisões condenatórias proferidas pelos Tribunais de Contas em processos de julgamento de contas decorrem do exercício de autêntica função jurisdicional administrativa, pois o princípio da unicidade da jurisdição em vigor no País não é absoluto, comportando exceções em virtude de normas de envergadura constitucional. Destarte, no sistema constitucional brasileiro, há casos pontuais de exercício da jurisdição por órgãos que não pertencem ao Poder Judiciário, de que são exemplo as decisões condenatórias proferidas pelos Tribunais de Contas. Tais exceções nada mais fazem que confirmar a regra, segundo a qual o exercício da jurisdição compete ao Poder Judiciário.

Conforme o mestre Hely Lopes Meirelles (1992 apud COSTA JÚNIOR, 2001, p. 81, grifo nosso), no contexto da significativa ampliação das atribuições institucionais dos Tribunais de Contas, "o poder de controle externo por eles exercido expressa-se, fundamentalmente, em funções de caráter técnico-opinativo e, também, de natureza jurisdicional-administrativa".

\subsection{Revisibilidade judicial}

Definida a natureza jurisdicional da função de julgar contas, contida no inciso II do art. 71 da CF, mister se faz averiguar a possibilidade de as decisões condenatórias proferidas em processos de contas serem revistas no âmbito do Poder Judiciário. Nesse sentido, a partir da verificação se as decisões condenatórias fazem ou não coisa julgada, podem-se perquirir eventuais limites a sua revisibilidade judicial ${ }^{30}$.

\subsubsection{Coisa julgada}

Segundo Cintra, Grinover e Dinamarco (2006), a sentença não mais susceptível de reforma por meio de recursos transita em julgado, tornando-se imutável dentro do processo. Nesse sentido, os autores distinguem a coisa julgada formal - pela qual a sentença, como ato

30 Como ponto de partida para se pensar os limites aplicáveis à revisibilidade judicial, faz-se oportuna a abordagem de Barroso (2011), que diferencia o "ativismo judicial" da "autocontenção judicial”. Para o autor, aquele é uma atitude, a escolha de um modo específico e proativo de interpretar a Constituição, expandindo seu sentido e alcance, estabelecendo-se via de regra em situações de retração do Poder Legislativo, de um certo descolamento entre a classe política e a sociedade civil. Seu oposto é a autocontenção judicial, conduta pela qual o Poder Judiciário procura reduzir suas interferências nas ações dos outros Poderes. 
de determinado processo, não mais pode ser reexaminada em virtude da preclusão de eventuais impugnações e recursos no âmbito daquele processo - da coisa julgada material, que representa a imutabilidade da sentença no mesmo processo ou em qualquer outro, entre as mesmas partes.

Fala-se ainda em coisa julgada administrativa, termo mais utilizado em países que adotam o sistema do contencioso administrativo. Nesse sentido, Di Pietro (1996) afirma que seria válido falar em coisa julgada administrativa, com o sentido de irretratabilidade ou imutabilidade da decisão final, apenas em países que integram o contencioso administrativo, o que não é o caso do Brasil. A autora supõe que, no sistema brasileiro, todos os processos administrativos seriam não-contenciosos, razão pela qual o termo "coisa julgada administrativa" significaria aqui tão-somente a impossibilidade da interposição de qualquer recurso perante a própria pública administração.

Seguindo o mesmo raciocínio, Ferraz (1999) nega a aptidão das decisões condenatórias proferidas pelos Tribunais de Contas para fazer coisa julgada material, as quais poderiam ser livremente questionadas em face do Poder Judiciário. $\mathrm{O}$ autor conclui que tais decisões poderiam ser revistas em sua plenitude pela Justiça Comum, a qual adentraria o mérito do julgamento de contas, com uma necessária comunicabilidade entre as instâncias cível (no Judiciário) e administrativa (nos Tribunais de Contas).

Tal raciocínio não merece prosperar. De fato, como afirma Di Pietro (1996), o Brasil adota o sistema da unicidade da jurisdição, mas tal sistema não é absoluto e comporta exceções, conforme mencionado no item 2.1.1 do presente trabalho. Entre tais exceções, encontra-se o processo administrativo de contas, que se torna contencioso uma vez que a regularidade destas seja questionada (ZYMLER, 2009). Decisões condenatórias das quais já não caiba a interposição de recursos perante os próprios Tribunais de Contas decorrem do exercício de autêntica função jurisdicional administrativa, ou seja, tais decisões formam coisa julgada, via de regra insusceptível de reforma pelo Poder Judiciário.

Questão óbvia, porém não menos importante, é a utilização do termo "julgar" no inciso II do art. 71 da $\mathrm{CF}$, que leva à conclusão do exercício da jurisdição pelos Tribunais de Contas e da consequente formação da coisa julgada em suas decisões definitivas. Maximiliano (1988 apud JACOBY FERNANDES, 1996, p. 56) afirma:

[...] o juiz atribui aos vocábulos o sentido resultante da linguagem vulgar; porque se presume haver o legislador, ou escritor, usado expressões comuns; porém, quando são empregados termos jurídicos, deve crer-se ter havido preferência pela linguagem técnica [...]. Enfim, todas as ciências, e entre elas 
o Direito, têm a sua linguagem própria, a sua tecnologia... No Direito Público usam mais dos vocábulos no sentido técnico; em o Direito Privado, na acepção vulgar.

Segundo Jacoby Fernandes (1996), a análise das competências das Cortes de Contas deve levar em conta o sentido técnico e próprio de cada um dos vocábulos empregados. Para o autor, o Tribunal de Contas, via de regra, "não tem competência para dizer o direito no caso concreto, de modo definitivo, com força de coisa julgada; por exceção detém essa competência, na forma do art. 71, inc. II, da Constituição Federal”.

Para Chaves (2009), contra as decisões dos Tribunais de Contas podem ser aviados recursos junto às próprias Cortes que as prolataram, tendo tais recursos a natureza de uma apelação administrativa. Para o autor, o ordenamento jurídico brasileiro não autoriza a previsão de recursos contra decisões dos Tribunais de Contas dirigidos ao Poder Judiciário ${ }^{31}$ ou ao Poder Legislativo, ou seja, todas as vias recursais devem se esgotar no âmbito do Tribunal de Contas competente para apreciar a matéria. Não cabe também a interposição de recurso dirigido a um Tribunal de Contas contra decisão proferida por outra Corte de Contas. Assim, por exemplo, não caberia recurso ao TCU de matéria julgada por TCE, dado que as competências de tais Cortes são distintas ${ }^{32}$.

\subsubsection{Limites à revisibilidade judicial}

Pode-se afirmar que existem duas principais correntes no que se refere aos eventuais limites aplicáveis à revisibilidade judicial das decisões condenatórias proferidas pelos Tribunais de Contas $^{33}$. A primeira corrente propugna que a função de julgamento de contas não teria caráter jurisdicional, tendo em vista o princípio da unicidade da jurisdição.

31 A apreciação, pelo Judiciário, de aspectos atinentes a nulidade formal ou ilegalidade manifesta, a exemplo da não-observância de quórum mínimo nas sessões colegiadas, da inclusão de processo em pauta sem a devida publicidade, da citação inválida e do cerceamento à ampla defesa e ao contraditório, ocorre por meio de ação ordinária, não tendo a natureza de recurso (CHAVES, 2009).

32 O TCU julga contas que envolvam recursos públicos federais e o TCE julga aquelas que envolvam recursos públicos estaduais e municipais, ressalvados os recursos públicos municipais cariocas e paulistanos, cujo julgamento de contas compete ao TCM-RJ e ao TCM-SP, respectivamente, bem como os recursos públicos pertencentes a Municípios localizados nos Estados da Bahia, Ceará, Goiás e Pará, cujos julgamentos competem, respectivamente, ao TCM-BA, ao TCM-CE, ao TCM-GO e ao TCM-PA.

33 Conforme já mencionado, a discussão sobre a natureza jurídica do julgamento de contas não é recente, havendo se debruçado sobre ela inclusive o eminente Ministro Victor Nunes Leal. Ao analisar o inciso II do art. 77 da Constituição de 1946, Leal (2003) constata que, enquanto alguns veem no julgamento de contas um puro ato administrativo, sujeito portanto à revisão judiciária, outros entendem que tal função é substancial e formalmente jurisdicional, escapando ao reexame por parte da justiça civil ou criminal. 
Consequentemente, tais decisões não seriam susceptíveis de fazer coisa julgada, podendo ser revistas em toda sua extensão pelo Poder Judiciário.

Já a segunda corrente, à qual se filia o autor desta monografia, defende a tese de que o julgamento de contas é autêntica função de cunho jurisdicional, de competência exclusiva dos Tribunais de Contas, tendo em vista exceção constitucionalmente estabelecida ao sistema da unicidade da jurisdição. Já que as Cortes de Contas exercem jurisdição especializada, suas decisões condenatórias formam coisa julgada, insusceptível de revisão judicial, ressalvado desrespeito ao princípio do devido processo legal ou eventual ilegalidade manifesta.

Pardini (1997 apud COSTA JÚNIOR, 2001, p. 61) classifica as funções desempenhadas pelos Tribunais de Contas em opinativa, fiscalizadora, corretiva e jurisdicional. Nesta, o Tribunal, com exclusividade, julga e liquida definitivamente as contas dos administradores e demais responsáveis por dinheiros, bens e valores públicos da administração direta e indireta e as contas daqueles que derem causa a perda, extravio ou outra irregularidade de que resulte prejuízo financeiro, econômico ou material ao erário e ao patrimônio da União. Trata-se, em verdade, de uma “jurisdição especializada de contas".

Ainda segundo Pardini (1997 apud BUGARIN, 2004, p. 77-78), o conteúdo jurisdicional da função desempenhada pelo Tribunal de Contas fundamenta-se na sua exclusiva competência para julgamento das contas públicas. Em tal função judicante, as contas são encerradas e liquidadas definitivamente com o julgamento do Tribunal de Contas, muito embora a responsabilidade do prestador possa vir a ser discutida novamente na Justiça Comum, mas tão-somente para decidir sobre eventuais lesões ao direito do impetrante, se a decisão contiver vícios de legalidade formal ou objetiva.

Seabra Fagundes ${ }^{34}$ (1984 apud BUGARIN, 2004, p. 75, grifos nossos), analisando a feição institucional do Tribunal de Contas, e após ressaltar que a Constituição Federal de 1967 admitia exceções ao monopólio jurisdicional do Poder Judiciário, reconhece o exercício da função judicante pelos Tribunais de Contas em processos de julgamento de contas, afirmando que o Poder Judiciário carece de jurisdição para examinar tal matéria. Afirma o autor, verbis:

O Tribunal de Contas não aparece na Constituição como órgão componente do Poder Judiciário. Dele se trata no capítulo referente ao Poder Legislativo,

34 Para mais detalhes, consultar a obra "O controle dos atos administrativos pelo Poder Judiciário", 4" ed, Rio de Janeiro: Forense, 1984. 
do qual constitui, pelo menos por algumas das suas atribuições, órgão auxiliar. Não obstante isso, o art. $71, \S 4^{\circ}$, lhe comete o julgamento da regularidade das contas dos administradores e demais responsáveis por bens e dinheiros públicos, o que implica em investi-lo no parcial exercício da função judicante. Não bem pelo emprego da palavra julgamento, mas sim pelo sentido definitivo da manifestação da corte, pois se a regularidade das contas pudesse dar lugar a nova apreciação (pelo Poder Judiciário), o seu pronunciamento resultaria em mero e inútil formalismo. Sob esse aspecto restrito (o criminal fica à Justiça da União) a corte de contas decide conclusivamente; os órgãos do poder judiciário carecem de jurisdição para reexaminá-lo.

No mesmo sentido, Speck (2000 apud VERINO, 2005, p. 35, grifo nosso) afirma:

Os defensores de um caráter plenamente judicial das decisões do TCU apontam para o fato de que o processo administrativo obedece a um rigor próximo do processo judicial quando separa instrução e julgamento, oferece ampla possibilidade de defesa e revisão, e segue, em outros aspectos, os princípios da legalidade e da imparcialidade. Tendo em vista essas características de tal processo, não faria sentido duplicar esse mesmo procedimento, com uma revisão plena no âmbito do Judiciário. O Julgamento do Tribunal de Contas se tornaria inútil e mero formalismo, se um juiz estivesse autorizado a julgar a mesma questão material ainda uma vez.

Pontes de Miranda (1970 apud COSTA JÚNIOR, 2001, p. 45-46, grifo nosso), na mesma esteira, reconhece o exercício da jurisdição pelos Tribunais de Contas e posiciona-se contrariamente a uma reapreciação, pelo Poder Judiciário, do que já foi julgado pelos Tribunais de Contas $^{35}$. Seus ensinamentos permanecem extremamente atuais, conforme transcrito a seguir:

Desde 1934, a função de julgar as contas estava, claríssima, no texto constitucional. Não havíamos de interpretar que o Tribunal de Contas julgasse, e outro juiz as rejulgasse depois. Trata-se de absurdo bis in idem... [...] e muito extravagante seria que, tendo a União o seu Tribunal de Contas, com atribuição explícita de julgar das contas dos responsáveis por dinheiros ou bens públicos, tivesse de subordinar tais contas aos juízes locais.

Jacoby Fernandes (1996), da mesma sorte, entende que a inalterabilidade da decisão é decorrência lógica, jurídica e inafastável da jurisdição. Se o Tribunal de Contas decide sobre questão jurídica que lhe foi submetida, mas essa decisão não merece o respeito dos órgãos do Judiciário, não há que se falar em jurisdição. Se as decisões definitivas das

35 Para um maior aprofundamento, consultar a obra "Comentários à Constituição de 1967 com a Emenda no 1 , de 1969”. Revista dos Tribunais: São Paulo, 1970. 
Cortes de Contas pudessem ser revistas pelo Poder Judiciário, não se poderia falar em coisa julgada nem em jurisdição. Portanto, não se estaria, tecnicamente, diante de um autêntico julgamento.

Nada obstante isto, Custódio (1991) dá notícia de que a maior parte das decisões judiciais admite a revisão, pelo Judiciário, das decisões proferidas pelo Tribunal de Contas. O próprio Superior Tribunal de Justiça (STJ) entende assim, conforme excertos da seguinte ementa:

EMENTA: PROCESSUAL CIVIL E ADMINISTRATIVO. AÇÃO DE IMPROBIDADE. RECEBIMENTO DA INICIAL. AGRAVO DE INSTRUMENTO. APROVAÇÃO DAS CONTAS PELO TRIBUNAL DE CONTAS DA UNIÃO. ART. 21, INC. II, DA LEI N N $^{\text {8.4. }}$.429/92. NÃO VINCULAÇÃO FRENTE AO PODER JUDICIÁRIO. POSSIBILIDADE DE IMPUGNAÇÃO VIA AÇÃO DE IMPROBIDADE ADMINISTRATIVA. FALTA DE PREQUESTIONAMENTO (ARTS. 267, INCS. I e VI e 295, INC. I E PAR. ÚNICO, INCS. I e III, DO CÓDIGO DE PROCESSO CIVIL). INOVAÇÃO EM SEDE DE EMBARGOS DE DECLARAÇÃO.

1. O Controle exercido pelo Tribunal de Contas, não é jurisdicional, por isso que não há qualquer vinculação da decisão proferida pelo órgão de controle e a possibilidade de ser o ato impugnado em sede de ação de improbidade administrativa, sujeita ao controle do Poder Judiciário, consoante expressa previsão do art. 21, inc. II, da Lei $\mathrm{n}^{\circ}$ 8.429/92. Precedentes: REsp 285305/DF, Primeira Turma, julgado em 20/11/2007, DJ 13/12/2007 p. 323; REsp 880662/MG, Segunda Turma, julgado em 15/02/2007, DJ 01/03/2007 p. 255; REsp 1038762/RJ, Segunda Turma, julgado em 18/08/2009, DJe $31 / 08 / 2009$.

$[\ldots]$

5. [...] Acrescente-se que atuação do TCU, na qualidade de Corte Administrativa não vincula a atuação do Poder Judiciário, nos exatos termos art. $5^{\circ}$, inciso XXXV, CF.88, segundo o qual, nenhuma lesão ou ameaça de lesão poderá ser subtraída da apreciação do Poder Judiciário. (fls. 1559).

6. A natureza do Tribunal de Contas de órgão de controle auxiliar do Poder Legislativo, decorre que sua atividade é meramente fiscalizadora e suas decisões têm caráter técnico-administrativo, não encerrando atividade judicante, o que resulta na impossibilidade de suas decisões produzirem coisa julgada e, por consequência não vincula a atuação do Poder Judiciário, sendo passíveis de revisão por este Poder, máxime em face do Princípio Constitucional da Inafastabilidade do Controle Jurisdicional, à luz do art. $5^{\circ}$, inc. XXXV, da CF/88.

7. A doutrina sobre o tema, assenta: No que diz respeito ao inciso II, referente ao Tribunal de Contas, a norma é de fácil compreensão. Se forem analisadas as competências do Tribunal de Contas, previstas no artigo $71 \mathrm{da}$ Constituição, vai-se verificar que o julgamento das contas das autoridades públicas não esgota todas as atribuições daquele colegiado, estando previsto nos incisos I e II; a apreciação das contas obedece a critérios políticos e não significa a aprovação de cada ato isoladamente considerado; as contas podem ser aprovadas, independentemente de um ou outro ato ou contrato ser considerado ilegal. Além disso, como o Tribunal de Contas não faz parte do 
Poder Judiciário, as suas decisões não têm forma de coisa julgada, sendo sempre passíveis de revisão pelo Poder Judiciário, com fundamento no artigo $5^{\circ}$, inciso XXV, da Constituição (Maria Sylvia Zanella Di Pietro in Direito Administrativo, 14a edição, São Paulo: Atlas, 2002, pp. 687/688).

[...]

12. Recurso Especial parcialmente conhecido e, nesta parte, desprovido. (STJ, Primeira Turma, REsp 1032732/CE. Relator: Min. Luiz Fux. Julgamento em 19/11/2009. Publicado no DJe de 03/12/2009, grifos nossos).

Os trechos grifados na suprarreferida decisão contêm lamentáveis equívocos. Primeiramente, a decisão confunde as competências previstas nos incisos I e II do art. 71 da Constituição, conferindo a tais atribuições, genericamente, a alcunha "julgamento de contas" e afirmando que as decisões dos Tribunais de Contas obedeceriam a critérios políticos. Ora, a competência contida no aludido inciso I distingue-se nitidamente daquela prevista no referido inciso II. Naquele, encontra-se estatuída a competência para a emissão de parecer prévio sobre as contas prestadas anualmente pelo Chefe do Poder Executivo, de caráter opinativo, para seu posterior julgamento pelo Congresso Nacional. Neste, encontra-se prevista a competência de julgamento das contas dos demais responsáveis por recursos públicos, uma função de caráter autenticamente jurisdicional.

Além disso, a decisão do STJ nega aos Tribunais de Contas o exercício da função jurisdicional, que se encontra presente na competência descrita no inciso II do art. 71 da CF, conforme se tem exaustivamente sustentado neste trabalho. Partindo do caráter não-judicial dos Tribunais de Contas - advindo do simples fato de tais órgãos não pertencerem à estrutura do Poder Judiciário -, a decisão nega peremptoriamente aos acórdãos proferidos em

julgamentos de contas a formação de coisa julgada, afirmando precipitadamente que as decisões das Cortes de Contas seriam sempre passíveis de revisão pelo Poder Judiciário.

Não é assim que entende o Supremo Tribunal Federal (STF). Em verdade, o STF - na condição de guardião da Constituição - tem conferido o devido valor às competências constitucionais outorgadas às Cortes de Contas, mormente quando se tem em vista o exercício da jurisdição especial de contas, prevista no inciso II do art. 71 da Carta Magna. A título exemplificativo, transcreve-se a seguinte ementa:

EMENTA: MANDADO DE SEGURANÇA. TRIBUNAL DE CONTAS DA UNIÃO. COMPETÊNCIA. ART. 71, II, DA CONSTITUIÇÃO DO BRASIL E ART. 5', II E VIII, DA LEI N. 8.443/92. TOMADA DE CONTAS ESPECIAL. VIOLAÇÃO AOS ARTS. 148 A 182 DA LEI N. 8.112/90. INOCORRÊNCIA. PROCEDIMENTO DISCIPLINADO NA LEI N. 8.443/92. AJUIZAMENTO DE AÇÃO CIVIL PÚBLICA. PREJUDICIALIDADE DA TOMADA DE CONTAS ESPECIAL. 
IMPOSSIBILIDADE. INDEPENDÊNCIA ENTRE AS INSTÂNCIAS CIVIL, PENAL E ADMINISTRATIVA. QUESTÃO FÁTICA. DILAÇÃO PROBATÓRIA. IMPOSSIBILIDADE. SEGURANÇA DENEGADA.

1. A competência do Tribunal de Contas da União para julgar contas abrange todos quantos derem causa a perda, extravio ou outra irregularidade de que resulte dano ao erário, devendo ser aplicadas aos responsáveis, em caso de ilegalidade de despesa ou irregularidade de contas, as sanções previstas em lei, lei que estabelecerá, entre outras cominações, multa proporcional ao dano causado aos cofres públicos [art. 71, II, da CB/88 e art. $5^{\circ}$, II e VIII, da Lei n. 8.443/92]. 2. A tomada de contas especial não consubstancia procedimento administrativo disciplinar. Tem por escopo a defesa da coisa pública, buscando o ressarcimento do dano causado ao erário. Precedente [MS n. 24.961, Relator o Ministro CARLOS VELLOSO, DJ 04.03.2005]. 3. Não se impõe a observância, pelo TCU, do disposto nos artigos 148 a 182 da Lei n. 8.112/90, já que o procedimento da tomada de contas especial está disciplinado na Lei n. 8.443/92. 4. O ajuizamento de ação civil pública não retira a competência do Tribunal de Contas da União para instaurar a tomada de contas especial e condenar o responsável a ressarcir ao erário os valores indevidamente percebidos. Independência entre as instâncias civil, administrativa e penal. 5. A comprovação da efetiva prestação de serviços de assessoria jurídica durante o período em que a impetrante ocupou cargo em comissão no Tribunal Regional do Trabalho da $1^{\text {a }}$ Região exige dilação probatória incompatível com o rito mandamental. Precedente [MS n. 23.625, Relator o Ministro MAURÍCIO CORRÊA, DJ de 27.03.2003]. 6. Segurança denegada, cassando-se a medida liminar anteriormente concedida, ressalvado à impetrante o uso das vias ordinárias. (STF, Tribunal Pleno, MS/25880. Relator: Min. Eros Grau. Julgamento em 07/02/2007. Publicado no DJ de 16/03/2007, grifos nossos).

Ao contrário do STJ, o STF estabelece cristalina distinção entre a competência de apreciação das contas do Chefe do Poder Executivo mediante a emissão de parecer prévio (art. 71, I, da CF) e a de julgamento de contas de responsáveis por recursos públicos. Veja-se o que afirma o Pretório Excelso diante de malfadada tentativa no sentido de limitar a jurisdição de contas exercida pelo TCE-MT e como o caráter definitivo do julgamento de contas é assinalado:

EMENTA: TRIBUNAL DE CONTAS DOS ESTADOS: COMPETÊNCIA: OBSERVÂNCIA COMPULSÓRIA DO MODELO FEDERAL: INCONSTITUCIONALIDADE DE SUBTRAÇÃO AO TRIBUNAL DE CONTAS DA COMPETÊNCIA DO JULGAMENTO DAS CONTAS DA MESA DA ASSEMBLÉIA LEGISLATIVA - COMPREENDIDAS NA PREVISÃO DO ART. 71, II, DA CONSTITUIÇÃO FEDERAL, PARA SUBMETÊ-LAS AO REGIME DO ART. 71, C/C. ART. 49, IX, QUE É EXCLUSIVO DA PRESTAÇÃO DE CONTAS DO CHEFE DO PODER EXECUTIVO. I. O art. 75, da Constituição Federal, ao incluir as normas federais relativas à "fiscalização" nas que se aplicariam aos Tribunais de Contas dos Estados, entre essas compreendeu as atinentes às competências institucionais do TCU, nas quais é clara a distinção entre a do art. 71, I - de apreciar e emitir parecer prévio sobre as contas do Chefe do Poder 
Executivo, a serem julgadas pelo Legislativo - e a do art. 71, II - de julgar as contas dos demais administradores e responsáveis, entre eles, os dos órgãos do Poder Legislativo e do Poder Judiciário. II. A diversidade entre as duas competências, além de manifesta, é tradicional, sempre restrita a competência do Poder Legislativo para o julgamento às contas gerais da responsabilidade do Chefe do Poder Executivo, precedidas de parecer prévio do Tribunal de Contas: cuida-se de sistema especial adstrito às contas do Chefe do Governo, que não as presta unicamente como chefe de um dos Poderes, mas como responsável geral pela execução orçamentária: tanto assim que a aprovação política das contas presidenciais não libera do julgamento de suas contas específicas os responsáveis diretos pela gestão financeira das inúmeras unidades orçamentárias do próprio Poder Executivo, entregue a decisão definitiva ao Tribunal de Contas. (STF, Tribunal Pleno, ADI 849/MT. Relator: Min. Sepúlveda Pertence. Julgamento em 11/02/1999. Publicado no DJ de 23/04/1999, grifos nossos).

Segundo Costa Júnior (2001), em que pese a existência de respeitáveis entendimentos em sentido contrário, a melhor doutrina é aquela que, calcada em princípios de lógica e hermenêutica irrefutáveis e corroborada pelos julgados do Excelso Pretório, atribui aos Tribunais de Contas o exercício da função jurisdicional, na medida em que lhes reconhece o poder de julgar as contas dos administradores, atribuindo a tal julgamento caráter definitivo, razão pela qual o mérito das contas julgadas não pode ser mudado por nenhum outro órgão jurisdicional.

Prossegue o autor afirmando que a revisibilidade das decisões proferidas pelos Tribunais de Contas somente é possível caso estejam eivadas de vícios de abuso de poder, em qualquer de suas espécies, excesso de poder ou manifesta ilegalidade. Nesse sentido, tais decisões só deixarão de prevalecer quando o procedimento violar a garantia do devido processo legal ou a decisão contiver manifesta ilegalidade, hipótese na qual, segundo Chaves (2009), a decisão deve ser desconstituída pelo Poder Judiciário e novamente apreciada pelo Tribunal de Contas, desta vez sem os vícios apontados.

Segundo Zymler e La Rocque Almeida (2008), a antiga Lei Orgânica do TCU (Lei no 830, de 23 de setembro de 1949) reconhecia a este Tribunal o exercício de função jurisdicional tamanha que previa inclusive a possibilidade de o TCU ordenar a prisão dos responsáveis que procurassem "ausentar-se furtivamente”. Reconhecia-se às Cortes de Contas o exercício da jurisdição contenciosa. ${ }^{36}$

Os autores prosseguem afirmando que, nada obstante a CF haver consagrado o sistema da unicidade da jurisdição, possibilitando assim o controle judicial sobre as decisões

36 Segundo Costa (2003, p. 68), “as decisões proferidas em tomadas de contas já se entendia assim no antigo Direito Imperial e, hoje por melhores razões, têm a autoridade e força de sentença dos tribunais de justiça e são executórias desde logo contra os mesmos responsáveis". 
do TCU, tal controle não é amplo e irrestrito, pois tais decisões só são passíveis de reforma quando caracterizada ilegalidade manifesta, preterição de formalidade legal ou violação da coisa julgada.

De fato, é exatamente dessa forma que entendeu o Pretório Excelso no julgamento do MS 7.280, cuja ementa a seguir se transcreve:

EMENTA: AO APURAR A ALCANCE DOS RESPONSAVEIS PELOS DINHEIROS PUBLICOS, O TRIBUNAL DE CONTAS PRATICA ATO INSUSCEPTIVEL DE REVISÃO NA VIA JUDICIAL A NÃO SER QUANTO AO SEU ASPECTO FORMAL OU TISNA DE ILEGALIDADE MANIFESTA. MANDADO DE SEGURANÇA NÃO CONHECIDO. (STF, Tribunal Pleno, MS 7280. Relator: Min. Henrique D'Avila. Julgamento em 20/06/1960. Publicado no DJ de 15/05/1961, grifo nosso).

No Voto do referido julgado do STF, o Relator afirma que "o Tribunal de Contas, quando da tomada de contas de responsáveis por dinheiros públicos, pratica ato insusceptível de impugnação na via judicial [...]", adotando como fundamento o julgado do Pretório Excelso no MS 6.960, de cujo Relatório transcreve-se o excerto a seguir:

A Constituição instituiu, em seu art. 77, II, um juízo constitucional de contas, a que a lei ordinária proveu de normas processuais próprias e específicas para o desempenho de sua finalidade. O que se apura, nessa jurisdição constitucional, é a exatidão das contas e a responsabilidade por essa exatidão de quantos arrecadam, guardam ou aplicam os dinheiros públicos. [...] "As decisões proferidas em tomadas de contas - já se entendia assim no antigo direito imperial, e hoje por melhores razões - têm a autoridade e força de sentença dos Tribunais de Justiça e são executórias desde logo contra os mesmos responsáveis" [...]. (STF, Tribunal Pleno, MS 6960/DF. Relator: Min. Ribeiro da Costa. Julgamento em 31/07/1959. Publicado no DJ de 27/08/1959, grifos nossos).

Portanto, ainda que sujeitas ao controle judicial, as decisões dos Tribunais de Contas, para Furtado (2007), justificam a adoção de controle judicial menos invasivo, devendo o Poder Judiciário promover a sua anulação somente em casos de aplicação absurda do Direito ou por falhas formais do processo, de que seria exemplo a não observância do contraditório ou da ampla defesa, os quais - frise-se - são amplamente assegurados pelo TCU, conforme inúmeros dispositivos constantes de seu Regimento Interno. O Judiciário, nesse sentido, não deve imiscuir-se na atividade de julgar contas, que é competência exclusiva dos Tribunais de Contas. 
Segundo Bugarin (2004), pode-se facilmente vislumbrar o caráter restritivo do poder revisional do Judiciário no que tange aos aspectos materiais/substanciais (mérito) do juízo constitucional de contas de competência privativa dos Tribunais de Contas. Para o autor, cabe ao Judiciário, sem dúvida, investigar eventual ocorrência, no decorrer do procedimento do julgamento de contas, de alguma lesão a direito de pessoas físicas e jurídicas submetidas à jurisdição de contas, sendo cristalino, no entanto, que não poderá haver reexame dos aspectos fáticos e jurídicos envolvendo a decisão material pela regularidade ou irregularidade das contas, ou seja, a atuação do Judiciário fica restrita aos aspectos jurídico-processuais concernentes aos princípios constitucionais que devem nortear todos os atos, legal e regimentalmente, concernentes à jurisdição especial de contas. Nesse sentido, a rediscussão judicial de toda a matéria já examinada por ocasião do julgamento de contas configura afronta ao princípio da eficiência da Administração Pública, insculpido no caput do art. 37 da CF.

E não há que se dizer que o inciso XXXV do art. $5^{\circ}$ da $\mathrm{CF}$ - o qual impede que a lei exclua da apreciação do Poder Judiciário lesão ou ameaça a direito - seria obstáculo ao entendimento segundo o qual o Judiciário carece de competência para revisar as decisões das Cortes de Contas. Isso porque, conforme afirma o Ministro Victor Nunes Leal (1960 apud JACOBY FERNANDES, 1996, p. 59), a competência das Cortes de Contas torna prejudicial e definitivo o pronunciamento sobre o fato material, "porque, no caso, a redução de competência do Judiciário resulta da Constituição, e não da lei”. Portanto, tais decisões não ficam excluídas da apreciação do Poder Judiciário, por força do disposto no inciso XXXV do art. $5^{\circ}$ da $\mathrm{CF}$, mas tal apreciação restringir-se-á tão-somente ao exame de sua legalidade (COSTA JÚNIOR, 2001).

\subsection{Eficácia das decisões condenatórias}

Nos termos do $\S 3^{\circ}$ do art. 71 da CF, “As decisões do Tribunal de que resulte imputação de débito ou multa terão eficácia de título executivo". Tal dispositivo constitucional tem importância chave no que se refere à execução das decisões condenatórias proferidas pelos Tribunais de Contas, revelando a intenção do legislador constituinte de atribuir a tais decisões força executiva compatível com a importância conferida aos Tribunais de Contas no panorama institucional brasileiro a partir da Constituição de 1988.

Nada obstante isto, autores há que não privilegiam as decisões proferidas pelos Tribunais de Contas, justamente em virtude de não reconhecerem a tais Cortes o exercício da 
jurisdição. Ferraz (1999), por exemplo, afirma que as controvérsias quanto à natureza das decisões condenatórias proferidas pelos Tribunais de Contas travam-se justamente com relação ao alcance da imputação do débito. Para o autor, se o título executivo representado pelo acórdão condenatório fosse de natureza judicial, dúvidas não existiriam acerca da natureza jurisdicional da função a cargo do Tribunal de Contas. No entanto, o art. 584 do $\mathrm{CPC}^{37}$ não reconhece os acórdãos condenatórios proferidos em julgamentos de contas como títulos executivos judiciais, o que implicaria classificá-los como títulos extrajudiciais, com a mesma força daqueles arrolados no art. 585 do CPC.

O equívoco de tal raciocínio já foi demonstrado no item 2.1.2 do presente trabalho. Não se pode confundir a natureza judicial de uma decisão - presente apenas quando esta houver sido proferida por órgão do Poder Judiciário - com seu caráter jurisdicional, que revela a aplicação do Direito ao caso concreto, ou seja, o exercício da jurisdição. Portanto, o fato de uma decisão não ser judicial não exclui a possibilidade de tal decisão possuir cunho jurisdicional.

Segundo Costa Júnior (2001), a executoriedade e a formação da coisa julgada são dois dos mais importantes elementos caracterizadores da atividade jurisdicional, mas os vocábulos jurisdição e judicial não são equivalentes. Para o autor, as decisões condenatórias não formam título judicial tão-somente porque as Cortes de Contas não estão compreendidas na estrutura do Poder Judiciário, o que não significa dizer que não possa existir atividade jurisdicional fora do Capítulo III do Título IV da CF, que diz respeito justamente a este Poder.

Certamente imbuído da necessidade de se conferir maior força executiva aos julgamentos de contas, o eminente e saudoso Ministro Fernando Gonçalves proferiu Voto que restou acolhido pelo Plenário do TCU, resultando na Decisão-TCU nº 331/1995 (YAMADA, 2005). Eis excertos do aludido Voto (grifos nossos):

[...] a eficácia das decisões dos Tribunais de Contas nos remete inevitavelmente ao polêmico tema da existência de função jurisdicional, ainda que restrita, atribuída àqueles órgãos, assunto este com o qual muitas vezes nos deparamos. Sem pretender repisar e exaurir matéria tão discutida, trago a este exame a opinião abalizada do ilustre Auditor aposentado do Tribunal de Contas do Distrito Federal, Raimundo de Menezes Vieira, no sentido de que o art. $5^{\circ}$, inciso XXXV, da Constituição Federal, ao dispor que a lei não excluirá da apreciação do Poder Judiciário lesão ou ameaça a direito, consagrou, como regra geral, o monopólio da função jurisdicional, cujas exceções, segundo ele, se consubstanciam nas seguintes hipóteses: a) a competência do Senado Federal de processar e julgar as autoridades enumeradas no art. 52 , inc. I e II da Constituição Federal, nos casos de

\footnotetext{
${ }^{37} \mathrm{O}$ art. 584 do CPC foi revogado pela Lei $\mathrm{n}^{\circ} 11.232$, de 2005.
} 
crime de responsabilidade; b) a competência dos Tribunais de Contas de julgar a "regularidade das contas dos administradores e demais responsáveis por bens e valores ou aplicação de bens ou fundos públicos [...], seja pelo descumprimento de qualquer outro preceito", caso lhes sejam imputados débito ou multa. Arrimando-se no juízo de doutrinadores de escol, como Seabra Fagundes e Victor Nunes Leal, o precitado jurista conclui: "[...] as decisões dos Tribunais de Contas referentes a imputação de débito ou multa se equiparam, por força de mandamento constitucional, às sentenças condenatórias proferidas por juízo monocrático ou aos acórdãos dos Tribunais Judiciários. São títulos judiciais por assemelhação e servem de base à propositura do processo de execução, independentemente de quaisquer outras formalidades" (Revista de Informação Legislativa, $\mathrm{n}^{\mathbf{0}}$ 106, págs. 103/108). [...] Se porventura alguma norma ordinária tivesse reconhecido, em relação às sentenças dos órgãos jurisdicionais, a similitude das decisões condenatórias dos Tribunais de Contas, atribuindo-lhes eficácia de título executivo judicial, as matérias passíveis de serem objeto de defesa, por meio de embargos do devedor, seriam muito mais restritas [...] No entanto, o atual art. 585 do CPC, após enumerar de forma exemplificativa os títulos executivos extrajudiciais, no inciso VII, permite a inclusão, naquele rol, de "todos os demais títulos" aos quais a lei atribuir força executiva, sob a forma de disposição expressa. [...] a posição mais consentânea é a que advoga que o art. 584 do mesmo diploma, ao discriminar os diversos títulos judiciais, o fez de maneira taxativa, não permitindo interpretações extensivas e analógicas. No entanto, de acordo com este entendimento, nada obsta que qualquer lei ordinária confira a uma outra sentença, diversa das relacionadas naquele dispositivo, a eficácia de título executivo judicial. [...] Deste modo, face à inexistência de uma norma, de mesma hierarquia, que conceda eficácia de título executivo judicial às decisões condenatórias dos Tribunais de Contas, e à impossibilidade de fazê-lo pela via interpretativa, resta apenas a subsunção de tais decisões na hipótese do inciso VII do art. 585, incluindoas no rol dos títulos executivos extrajudiciais. Tal situação traz como corolário a desarrazoada inserção daqueles arestos na vala comum das notas promissórias, contratos de hipoteca, duplicatas, etc., e a incompatível faculdade de o executado alegar, em embargos, quaisquer outras matérias já discutidas no processo que deu origem ao aresto embargado, o que obviamente contraria o caráter definitivo das decisões das Cortes de Contas. Certamente isto não pode e nem deve continuar. [...] Ademais, o inegável fato de que já existe, na doutrina e na jurisprudência dos órgãos do Poder Judiciário, o reconhecimento da função jurisdicional especial dos Tribunais de Contas, e o atual sucesso do processo de reforma constitucional, ora em curso no Congresso Nacional, dão-me o alento necessário para crer numa razoável chance de lograrmos a sensibilização dos ilustres parlamentares para as necessárias mudanças no $\S 3^{\circ}$ do art. 71 da Carta Magna, consistentes na atribuição de eficácia de título executivo judicial às decisões deste Tribunal, e na imputação de inelegibilidade e inabilitação para a prática de atos de natureza patrimonial. Isto posto, Voto no sentido de que Tribunal adote a Decisão que ora submeto à deliberação deste Plenário.

A aludida Decisão autorizou a Presidência do TCU a encaminhar ao Congresso Nacional sugestão de emenda constitucional, propondo nova redação ao $\S 3^{\circ}$ do art. 71 , nos seguintes termos (grifo nosso): 
As decisões do Tribunal de que resulte imputação de débito ou multa terão eficácia de título executivo judicial, ficando o respectivo responsável inelegível e inabilitado para praticar atos de natureza patrimonial, enquanto não comprovar perante aquele órgão o ressarcimento do débito e o pagamento da multa.

A sugestão do Egrégio Plenário do TCU surtiu inicialmente algum efeito na Câmara dos Deputados, haja vista a apresentação da Proposta de Emenda à Constituição (PEC) $\mathrm{n}^{\circ} 535$, de 1997, propondo nova redação ao $\S 3^{\circ}$ do art. 71 nos exatos termos sugeridos pelo Tribunal. Nada obstante isto, a proposta restou arquivada pela Câmara dos Deputados em 31/01/2011, nos termos do art. 105 de seu Regimento Interno ${ }^{38}$.

A visão segundo a qual às decisões condenatórias deveria ser atribuída eficácia de título executivo judicial é perfilhada por Martinez (2006). Após destacar que, sob o prisma do pluralismo jurídico, o dogma da exclusividade do Poder Judiciário para a resolução de conflitos deve ser afastado, o autor cita os casos da justiça desportiva - cujas instâncias devem ser esgotadas em ações relativas à disciplina e às competições esportivas antes do acesso ao Judiciário, conforme o art. 217, § $1^{\circ}$, do texto constitucional - e dos juizados $\operatorname{arbitrais}^{39}$, cuja sentença é considerada, por força de lei, título executivo judicial, conforme previsto no inciso IV do art. 475-N do CPC, incluído pela Lei no 11.232, de 2005.

A partir de tais exceções, o referido autor entende que os acórdãos condenatórios dos tribunais de contas deveriam ser dotados da qualidade de títulos executivos judiciais, de vez que a jurisdição especial de contas decorre expressamente da CF.

Com a devida venia aos respeitáveis entendimentos acima, cujo escopo de valorização dos julgados dos Tribunais de Contas revela-se extremamente louvável, entendese - como já mencionado - que, não pertencendo os Tribunais de Contas ao Poder Judiciário, as decisões por eles proferidas não são judiciais, mas extrajudiciais, o que inobstante não significa equipará-las a todo e qualquer título extrajudicial, sob pena de se transformar todo o

38 O art. 105 do Regimento Interno da Câmara dos Deputados determina que, finda a legislatura, arquivar-se-ão todas as proposições que, no seu decurso, tenham sido submetidas à deliberação da Câmara e ainda se encontrem em tramitação. Conforme o parágrafo único do mesmo artigo, a PEC 535, de 1997, poderia ter sido desarquivada mediante requerimento do Autor, dentro dos primeiros cento e oitenta dias da primeira sessão legislativa ordinária da legislatura subsequente.

39 O enquadramento das decisões proferidas pelos juizados arbitrais, no inciso IV do art. 475-N do CPC, como títulos executivos judiciais é, no mínimo, uma imprecisão técnica. Todos os demais incisos do mencionado artigo trazem títulos decorrentes de decisões proferidas por órgãos do Poder Judiciário. Como os juizados arbitrais não pertencem ao Poder Judiciário, o mais adequado seria classificar tais títulos como extrajudiciais, em que pese o disposto no art. 31 da Lei $\mathrm{n}^{\circ}$ 9.307, de 1996, segundo o qual a "sentença arbitral produz, entre as partes e seus sucessores, os mesmos efeitos da sentença proferida pelos órgãos do Poder Judiciário e, sendo condenatória, constitui título executivo". 
esforço procedimental de autêntico cunho jurisdicional das Cortes de Contas em um nada, mormente quando se tem em vista o disposto no art. 745, V, do CPC, segundo o qual, diante dos títulos executivos extrajudiciais, pode o devedor alegar qualquer matéria que lhe seria lícito deduzir no processo de conhecimento. Tal questão será abordada com mais detalhes no próximo capítulo. 


\section{EXECUÇÃO JUDICIAL DAS DECISÕES CONDENATÓRIAS}

Conforme abordado no primeiro capítulo deste trabalho, verificada a irregularidade das contas, o Relator ou o Tribunal, caso haja débito, ordenará a citação do responsável para que, no prazo de quinze dias, apresente suas alegações de defesa e/ou recolha a importância devida. Caso não haja débito, determinar-se-á a audiência do responsável para que, em igual prazo, apresente suas razões de justificativa. ${ }^{40}$

Uma vez garantidos o contraditório e a ampla defesa, caso o TCU entenda que a irregularidade persiste e o interessado não recolha a quantia correspondente ao débito que lhe tiver sido imputado ou à multa que lhe houver sido cominada, será proferida decisão definitiva $^{41}$ no sentido da irregularidade das contas, de cunho eminentemente condenatório.

A partir da publicação da decisão condenatória no Diário Oficial da União, o interessado deverá comprovar, perante o Tribunal, o pagamento da quantia correspondente ao débito imputado e/ou à multa cominada, para o que será devidamente notificado ${ }^{42}$.

Caso não efetue o recolhimento no prazo de quinze dias contados da publicação da decisão no Diário Oficial, e se não houver sido autorizado o parcelamento, o Tribunal determinará o desconto integral ou parcelado da dívida na remuneração do responsável, caso seja agente público ou, alternativamente, autorizará a cobrança judicial da dívida, por intermédio do Ministério Público junto ao Tribunal (MP/TCU), a partir do título executivo extrajudicial consubstanciado no acórdão condenatório ${ }^{43}$.

\subsection{A execução de títulos judiciais e extrajudiciais}

A Lei $n^{\circ} 5.869$, de 11 de janeiro de 1973 (CPC em vigor), tratava da mesma forma, em sua estrutura originária, a execução de títulos judiciais e extrajudiciais: o executado

40 O Manual de Instrução de Processos de Tomada e Prestação de Contas, aprovado pela Portaria-TCU n ${ }^{\circ} 105$, de 2004, estabelece os seguintes conceitos:

- Audiência - procedimento pelo qual o Relator ou o Tribunal, verificada irregularidade das contas sem ocorrência de débito, chama o responsável para apresentar razões de justificativa.

- Citação - procedimento pelo qual o Relator ou o Tribunal, verificada irregularidade nas contas com ocorrência de débito, chama o responsável para apresentar defesa ou recolher a quantia devida.

41 Ressalva-se eventual interposição de recursos com efeito suspensivo perante o próprio TCU, conforme mencionado no item 1.5.1.

42 Segundo o Manual de Instrução de Processos de Tomada e Prestação de Contas, notificação vem a ser a "comunicação processual por meio da qual o responsável é chamado para efetuar e comprovar o recolhimento do débito imputado ou da multa cominada".

43 Os procedimentos envolvidos desde a constatação da irregularidade até a autorização para a cobrança judicial da dívida constam dos arts. 201 a 220 do RITCU. 
era citado para, em 24 horas, pagar ou nomear bens à penhora, daí se seguindo as medidas executivas destinadas à expropriação, com prioridade para a arrematação em hasta pública. Tal procedimento também era aplicável à execução fiscal, sendo marcante como, na redação originária do CPC, a execução fundada em título judicial, a execução fundada em título extrajudicial e a execução fiscal estavam todas sujeitas ao mesmo procedimento (CUNHA, 2007).

A partir da edição da Lei n 6.830, de 22 de setembro de 1980 (Lei de Execuções Fiscais - LEF), a cobrança judicial da dívida ativa - uma categoria de título executivo extrajudicial, conforme art. 585, VII, do CPC - da União, Estados, Distrito Federal, Municípios e respectivas autarquias (execução fiscal) passou a contar com algumas garantias ou benefícios não presentes, até então, na execução civil regulada pelo CPC (CUNHA, 2007). Manteve-se, entretanto, uma uniformidade no tratamento conferido aos títulos extrajudiciais em geral e aos títulos judiciais no que tange ao procedimento para sua execução.

Nada obstante isto, tal uniformidade na execução da obrigação de pagamento de quantia certa foi definitivamente quebrada com a edição da Lei ${ }^{\circ} 11.232$, de 22 de dezembro de 2005, a qual alterou dispositivos do CPC para instituir a fase do "cumprimento de sentença”. De acordo com tal instituto, a execução de títulos judiciais passou a ser realizada como uma fase dentro do mesmo processo em que se operou a cognição, ou seja, o processo autônomo de execução para títulos judiciais foi, via de regra, extinto ${ }^{44}$.

Mas a execução fundada em títulos extrajudiciais também foi reformada ${ }^{45}$. Com o advento da Lei $\mathrm{n}^{\circ} 11.382$, de 6 de dezembro de 2006, operaram-se importantes alterações no CPC no que toca à execução de títulos extrajudiciais, importando - para os fins deste trabalho - quatro aspectos concernentes à defesa do devedor: a) matérias alegáveis; b) termo inicial para a interposição; c) efeito suspensivo; d) segurança do juízo.

Tais aspectos atinentes à defesa do executado serão comparados - à luz do direito positivo - na execução de títulos judiciais, na execução de títulos extrajudiciais e na execução fiscal, para, em seguida, abordar-se o procedimento aplicável à execução judicial das decisões condenatórias proferidas pelos Tribunais de Contas. ${ }^{46,47}$

44 Exceção feita à sentença penal condenatória, à sentença arbitral e à sentença estrangeira homologada pelo STJ (art. 475-N, II, IV e VI do CPC), cujas execuções requerem processo autônomo de execução por não ter havido prévio processo de conhecimento no juízo cível.

45 Em virtude da ausência de processo de conhecimento prévio à execução de títulos extrajudiciais, esta se dá na seara judicial por meio de processo executivo específico.

46 Apesar do tratamento diferenciado conferido, pelo direito positivo, à execução de títulos judiciais, à execução de títulos extrajudiciais e à execução fiscal, Didier Junior et al (2009) entendem que a reforma processual operada em 2006 no que se refere ao procedimento executivo de títulos extrajudiciais teve profundos reflexos 


\subsubsection{Execução de títulos judiciais}

Os títulos executivos judiciais encontram-se arrolados no art. 475-N do CPC. Sua execução não implica a necessidade de constituição de um processo autônomo de execução, à exceção daqueles elencados nos incisos II, IV e VI do citado artigo, que requerem a citação do devedor, conforme previsto em seu parágrafo único. O título executivo judicial tipicamente executado no juízo cível é a sentença proferida no processo civil (inciso I).

As sentenças podem ser classificadas, consoante concepção trinária, em declaratórias, constitutivas e condenatórias. As primeiras visam única e exclusivamente à declaração da existência ou inexistência da relação jurídica, enquanto as segundas objetivam, além da declaração, a modificação da situação jurídica posta em juízo, podendo modificar, constituir ou extinguir direitos. Tanto as sentenças declaratórias quanto as constitutivas prescindem da atividade jurisdicional executiva para que venham a produzir efeitos no plano prático (MONNERAT, 2007).

Nesse sentido, segundo Marinoni (2004 apud MONNERAT, 2007, p. 148): “as tutelas declaratórias e constitutivas bastam por si só. São, por assim dizer, tutelas jurisdicionais 'auto-implementáveis', 'auto suficientes', que dispensam qualquer providência do réu ou do aparato judiciário para que seus efeitos sejam sentidos regularmente".

A seu turno, a terceira categoria de sentenças diz respeito às condenatórias. Tais sentenças são aquelas que, além de declarar o direito, possuem uma autorização de acesso à via jurisdicional executiva. Segundo Monnerat (2007), para que a sentença condenatória opere efeitos práticos, o magistrado pode utilizar dois mecanismos: a) a técnica mandamental, em que consta na própria decisão condenatória uma ordem para que o condenado cumpra o determinado na sentença, ordem esta que, caso desobedecida, implica alguma sanção, já contida na sentença, ou fixada ou modificada pelo juiz, após o ato decisório ${ }^{48}$; e b) a técnica executiva, em que o magistrado, no lugar de se valer de medidas coercitivas, vale-se de atos

sobre a execução fiscal e sobre a própria execução de títulos judiciais. Assim, por exemplo, os autores entendem que os embargos do devedor na execução fiscal podem ser interpostos a partir da citação e não a partir da penhora, apesar do que preceitua a LEF. Da mesma sorte, na execução de títulos judiciais, os autores entendem possível o oferecimento da impugnação ao cumprimento de sentença antes da penhora.

47 Alguns doutrinadores, como Assis (2008), aludem à possibilidade de defesa por meio da chamada exceção de pré-executividade antes da penhora. Trata-se de instituto construído doutrinariamente, sem previsão expressa no CPC, não fazendo parte do escopo deste trabalho abordá-lo.

48 A técnica mandamental se faz presente nas determinações do TCU. Nesse sentido, o art. $58, \S 1^{\circ}$, da LOTCU estabelece que ficará sujeito à multa aquele que deixar de dar cumprimento à decisão do Tribunal, salvo motivo justificado. 
executivos de sub-rogação nos quais agentes estatais agem em substituição à vontade do executado. $^{49}$

Portanto, as sentenças de natureza condenatória podem ensejar sua execução judicial caso não haja cumprimento voluntário pelo devedor. Conforme já mencionado, a partir da reforma processual operada em 2005, as execuções de títulos judiciais deixaram de requerer a constituição de processo autônomo de execução, ou seja, as sentenças condenatórias passaram a ser executadas como uma fase do próprio processo a partir do qual emanou o título (MARINONI, 2008).

Feitas tais considerações, importa mencionar os principais aspectos concernentes à defesa do devedor na execução de títulos judiciais que tenham por objeto obrigação de pagamento de quantia certa.

Nos termos do art. 475-J do CPC, caso o devedor não pague a quantia devida no prazo de quinze dias, o montante da condenação será acrescido de multa no percentual de dez por cento, podendo ser expedido mandado de penhora e avaliação, a requerimento do credor. Consoante o $\S 1^{\circ}$ do mesmo artigo, do auto de penhora será imediatamente intimado o executado, que poderá oferecer impugnação, também no prazo de quinze dias.

Aspecto fundamental na fase de cumprimento de sentença diz respeito às matérias que podem ser alegadas pelo devedor na impugnação. Nesse sentido, o art. 475-L do CPC restringe o objeto desta impugnação às hipóteses elencadas taxativamente em seus incisos. Além disso, a impugnação, via de regra, não possui efeito suspensivo, conforme estabelecido no art. 475-M do Código, podendo o juiz atribuir-lhe tal efeito desde que relevantes seus fundamentos e o prosseguimento da execução seja manifestamente suscetível de causar ao executado grave dano de difícil ou incerta reparação.

Portanto, a defesa do executado na fase de cumprimento de sentença, por meio de impugnação, reveste-se dos seguintes aspectos: a) as matérias alegáveis estão restritas àquelas elencadas no art. 475-L do CPC; b) a impugnação só pode ser apresentada após a intimação da penhora; c) a impugnação não possui, via de regra, efeito suspensivo; d) para o oferecimento da impugnação, o juízo deve estar garantido por meio da penhora.

\footnotetext{
49 Alguns doutrinadores entendem que as técnicas mandamental e executiva consubstanciam-se, na verdade, em duas espécies autônomas de sentenças, razão pela qual optam por uma classificação quinária. Tal visão é rechaçada por Theodoro Junior (2006 apud MONNERAT, 2007, p. 149-150), para quem a classificação trinária (sentenças declaratórias, constitutivas e condenatórias) leva em conta o conteúdo do ato decisório, ao passo que as supostas categorias mandamental e executiva lastreiam-se nos efeitos de certa sentença. Para o doutrinador, é um erro estruturar uma classificação com base em mais de um critério distintivo.
} 


\subsubsection{Execução de títulos extrajudiciais}

$\mathrm{O}$ art. 585 do CPC arrola, em rol exemplificativo, os títulos executivos extrajudiciais, estabelecendo, em seu inciso VIII, que detêm o status de títulos executivos extrajudiciais "todos os demais títulos a que, por disposição expressa, a lei atribuir força executiva". Requisito indispensável ao ajuizamento da ação de execução é que o título consubstancie obrigação certa, líquida e exigível (art. 586 do CPC).

Segundo Marinoni (2008), o título executivo gera a presunção da existência do direito, mas tal presunção é relativa, comportando a demonstração da inexistência do direito pelo devedor, por meio dos embargos à execução. Estes possuem a natureza de ação de conhecimento autônoma e incidente ao processo de execução, pois a defesa do executado não pode ser feita, via de regra, no processo de execução, o qual foi pensado não para a cognição sobre o crédito exigido em seu bojo, mas apenas para realizar direito já reconhecido.

Com a reforma processual operada por força da Lei $\mathrm{n}^{\circ} 11.382$, de 2006, a execução judicial de tais títulos teve seu rito substancialmente alterado. Assim, a nova redação do art. 652 do CPC estabelece que o executado será citado para, no prazo de três dias, efetuar o pagamento da dívida ${ }^{50}$. Caso não haja pagamento, o oficial de justiça procederá de imediato à penhora dos bens e a sua avaliação, lavrando o respectivo auto e intimando, de tais atos, o executado (art. 652, $\S 1^{\circ}$ do CPC). Nos termos do $\S 2^{\circ}$ do mesmo artigo, o exequente poderá indicar, na inicial da execução, os bens a serem penhorados. Já o $\S 3^{\circ}$ preceitua que o juiz poderá, de ofício ou a requerimento do exequente, determinar, a qualquer tempo, a intimação do executado para indicar bens passíveis de penhora.

A nova redação conferida ao art. 736 do CPC pela Lei $n^{\circ} 11.382$, de 2006, estabelece que o executado, independentemente de penhora, depósito ou caução, poderá oporse à execução por meio de embargos, não havendo mais, portanto, a necessidade de garantia do juízo para a interposição dos embargos à execução, que passaram a ser oponíveis no prazo de quinze dias contados da data de juntada aos autos do mandado de citação (art. 738 do CPC) ${ }^{51}$ Além disso, os embargos à execução não possuem mais, via de regra, efeito

50 O art. 652-A estabelece que o juiz, ao despachar a inicial, fixará, de plano, os honorários advocatícios a serem pagos pelo executado, prevendo em seu parágrafo único uma sanção premial, segundo a qual, no caso de integral pagamento no prazo de três dias, a verba honorária será reduzida pela metade.

51 Vale citar, neste particular, o célebre “caso Mannesmann”. Em 1966, várias demandas executivas foram interpostas contra a companhia siderúrgica Mannesmann a partir de títulos extrajudiciais com assinaturas forjadas por um dos diretores da empresa. Para evitar a falência da companhia, Pontes de Miranda lançou mão, em parecer, da "exceção de pré-executividade" - uma criação doutrinária e jurisprudencial -, de forma a permitir a defesa da empresa, já que a propositura dos embargos do devedor exigiria, à época, a prévia garantia do juízo por meio da penhora de bens da Mannesmann (CÂMARA, 2008). A alteração legislativa 
suspensivo, muito embora possa o juiz atribuir-lhes tal efeito, a pedido do embargante, quando, sendo relevantes os fundamentos dos embargos, o prosseguimento da execução manifestamente possa causar ao executado grave dano de difícil ou incerta reparação, e desde que a execução já esteja garantida por penhora, depósito ou caução suficientes (art. 739-A, caput e $\S 1^{\circ}$, do CPC).

No que tange às matérias alegáveis em sede de embargos à execução, o executado pode alegar as matérias elencadas exemplificativamente no art. 745 do CPC. De acordo com o inciso V de tal artigo, o embargante pode alegar "qualquer matéria que lhe seria lícito deduzir como defesa em processo de conhecimento".

É ainda possível ao executado, com fundamento no art. 746 do CPC, oferecer os chamados embargos de segunda fase (DIDIER JUNIOR ET AL, 2009), no prazo de cinco dias contados da adjudicação, alienação ou arrematação, fundados em nulidade da execução ou em causa extintiva da obrigação, desde que superveniente à penhora. ${ }^{52}$

Assim, a defesa do executado na execução de títulos extrajudiciais por meio de embargos à execução apresenta os seguintes aspectos principais: a) o embargante pode alegar qualquer matéria que lhe seria lícito deduzir como defesa no processo de conhecimento; b) os embargos podem ser opostos a partir da citação; c) não há, via de regra, efeito suspensivo; d) não há obrigatoriedade de garantia do juízo.

\subsubsection{Execução fiscal}

Entre os títulos executivos extrajudiciais arrolados no art. 585 do CPC, avultam em importância aqueles elencados em seu inciso VII, correspondentes à "certidão de dívida ativa da Fazenda Pública da União, dos Estados, do Distrito Federal, dos Territórios e dos Municípios, correspondente aos créditos inscritos na forma da lei”.

A Lei no 6.830, de 1980 (LEF), dispõe sobre a cobrança judicial da dívida ativa da Fazenda Pública, estabelecendo, em seu art. $2^{\circ}$, que constitui dívida ativa da Fazenda Pública “aquela definida como tributária ou não tributária na Lei n 4.320, de 17 de março de 1964".

empreendida por meio da Lei $\mathrm{n}^{\mathrm{o}}$ 11.382, de 2006, passou a permitir a oposição dos embargos independentemente da penhora, o que representou um avanço para se evitar situações como a vivenciada pela Mannesmann. Obviamente, as decisões condenatórias proferidas pelos Tribunais de Contas em processos nos quais são garantidas ao interessado o contraditório e a ampla defesa não podem ser tratadas da mesma forma que títulos de crédito forjados.

52 Tendo em vista os embargos de segunda fase, Didier Junior et al (2009) entendem que seria cabível a "impugnação de segunda fase" na execução de títulos judiciais. Não há, entretanto, previsão expressa no CPC para tal modalidade de impugnação. 
A dívida ativa tributária e a não tributária encontram-se definidas no art. $39, \S 2^{\circ}$, desta Lei, conforme será abordado no item 3.2.

A execução fiscal, portanto, é aquela que se realiza a partir da certidão de dívida ativa, uma espécie sui generis de título executivo extrajudicial. Tendo em vista as especificidades de tal título, o legislador ordinário optou por conferir-lhe um procedimento de execução judicial diferenciado, previsto na LEF. Nos termo do art. $1^{\circ}$ desta Lei, a execução fiscal é regida pela LEF, aplicando-se subsidiariamente as disposições do CPC.

A nova redação do art. 652 do CPC, aplicável à execução dos títulos extrajudiciais em geral, não se aplica à execução fiscal. Nos termos dos arts. $8^{\circ}$ e $9^{\circ}$ da LEF, o executado será citado para, no prazo de cinco dias, pagar a dívida com os juros e multa de mora e encargos indicados na certidão de dívida ativa, ou garantir a execução com depósito em dinheiro, com fiança bancária ou com a nomeação de bens à penhora, observada a ordem prevista no art. 11 da própria LEF (CUNHA, 2007). O executado poderá ainda garantir a execução por meio da indicação à penhora de bens oferecidos por terceiros e aceitos pela Fazenda Pública (art. 9º IV, da LEF).

Importa observar que, por força do disposto no art. 53 e seus parágrafos da Lei $\mathrm{n}^{\circ}$ 8.212, de 24 de julho de 1991, na execução judicial da dívida ativa da União, suas autarquias e fundações públicas, é facultado ao exequente indicar bens à penhora, a qual será efetivada concomitantemente com a citação inicial do devedor, com a consequente indisponibilidade dos bens. Contudo, efetuado o pagamento integral da dívida executada, com seus acréscimos legais, no prazo de dois dias úteis contados da citação, poderá ser liberada a penhora, desde que não haja outra execução pendente. ${ }^{53}$

De acordo com o art. 16 da LEF, o prazo para a oposição de embargos à execução é de trinta dias, contados do depósito, da juntada da prova da fiança bancária ou da intimação da penhora. Portanto, a propositura dos embargos à execução necessariamente implica, na execução fiscal, a garantia do juízo.

No que se refere aos efeitos dos embargos na execução fiscal, a LEF silencia, devendo-se aplicar as disposições do CPC. Conforme mencionado no item anterior, os embargos à execução não possuem, via de regra, efeito suspensivo, podendo o juiz atribuirlhes tal efeito desde que presentes certos requisitos (art. 739-A do CPC). Portanto, a execução fiscal normalmente não é suspensa pela oposição dos embargos.

53 Segundo Cunha (2007), tal sistemática aplica-se apenas na execução fiscal proposta pela União, suas autarquias e fundações, ou seja, quando o exequente for uma Fazenda Pública estadual ou municipal, não há previsão legal para a indicação de bens à penhora na própria petição inicial. 
Já no que toca às matérias alegáveis em sede de embargos, o art. 16, § $2^{\circ}$, da LEF estabelece que "o executado deverá alegar toda matéria útil à defesa, requerer provas e juntar aos autos os documentos e rol de testemunhas, até três, ou, a critério do juiz, até o dobro desse limite". As matérias alegáveis são, portanto, bem amplas, com as restrições do $\S 3^{\circ}$ do mesmo art. 16, que veda a reconvenção e a compensação ${ }^{54}$.

Portanto, os embargos à execução fiscal possuem as seguintes particularidades: a) a matéria alegável é ampla, não sendo admitida, contudo, a reconvenção e a compensação; b) só podem ser oferecidos após o depósito, a juntada de prova da fiança bancária ou a intimação da penhora; c) não há, via de regra, efeito suspensivo; d) há necessidade de garantia do juízo.

\subsection{Rito executivo das decisões condenatórias}

Conforme abordado no item 3.1.1 do presente trabalho, as sentenças judiciais podem ter conteúdo declaratório, constitutivo e condenatório. Apenas as sentenças condenatórias sujeitam-se à execução judicial (MARINONI, 2008; MONNERAT, 2007).

Considerando o conteúdo condenatório das decisões definitivas proferidas pelos Tribunais de Contas no sentido da irregularidade das contas (COSTA JUNIOR, 2001), com a consequente imputação de débito ou cominação de multa ao responsável, e tendo em vista a jurisdição especial de contas, que restou estabelecida constitucionalmente como exceção ao princípio da unicidade da jurisdição, autores há que defendem a classificação de tais decisões como títulos executivos judiciais.

Martinez (2006), por exemplo, propugnava pela inclusão, no rol de títulos executivos judiciais estabelecido pelo revogado art. 584 do $\mathrm{CPC}^{55}$, de inciso específico que enquadrasse os acórdãos condenatórios dos Tribunais de Contas como títulos executivos judiciais.

Segundo Jacoby Fernandes (2008), a apreciação dos atos da Administração Pública, desenvolvida pelos Tribunais de Contas, resulta em um ato jurídico equivalente a uma sentença, na medida em que declara a regularidade ou irregularidade da conduta de um agente na guarda e/ou na aplicação dos recursos públicos.

Apesar dos respeitáveis entendimentos em sentido diverso, entende-se que as decisões condenatórias proferidas pelos Tribunais de Contas são títulos executivos

\footnotetext{
54 Observe-se que a compensação, embora não possa ser alegada nos embargos à execução fiscal, pode ser objeto da impugnação ao cumprimento de sentença, conforme art. 475-L, VI, do CPC.

$55 \mathrm{O}$ rol de títulos executivos judiciais encontra-se situado no art. 475-N do CPC em vigor.
} 
extrajudiciais. Conforme mencionado no item 2.3 desta monografia, tais decisões não são títulos judiciais pelo simples fato de as Cortes de Contas não pertencerem ao Poder Judiciário.

Tal entendimento acarretaria, a princípio, a submissão das decisões condenatórias proferidas pelos Tribunais de Contas ao regime de execução de títulos extrajudiciais de que trata o item 3.1.2 deste capítulo, com a consequente desnecessidade da garantia do juízo para a oposição dos embargos à execução, que poderiam ser oferecidos a partir da citação.

É preciso que se tenha em conta, todavia, que a LEF considera dívida ativa da Fazenda Pública, em seu art. $2^{\circ}$, aquela definida como tributária ou não tributária, nos termos da Lei n 4.320, de 1964, a qual estatui normas gerais de Direito Financeiro para elaboração e controle dos orçamentos e balanços da União, dos Estados, dos Municípios e do Distrito Federal (ver item 3.1.2).

Nos termos do $\S 2^{\circ}$ do art. 39 da Lei $n^{\circ} 4.320$, de 1964, verbis (grifo nosso):

$\S 2^{\circ}$ - Dívida Ativa Tributária é o crédito da Fazenda Pública dessa natureza, proveniente de obrigação legal relativa a tributos e respectivos adicionais e multas, e Dívida Ativa não Tributária são os demais créditos da Fazenda Pública, tais como os provenientes de empréstimos compulsórios, contribuições estabelecidas em lei, multa de qualquer origem ou natureza, exceto as tributárias, foros, laudêmios, alugueis ou taxas de ocupação, custas processuais, preços de serviços prestados por estabelecimentos públicos, indenizações, reposições, restituições, alcances dos responsáveis definitivamente julgados, bem assim os créditos decorrentes de obrigações em moeda estrangeira, de subrogação de hipoteca, fiança, aval ou outra garantia, de contratos em geral ou de outras obrigações legais.

Conforme o trecho acima grifado, os valores condenatórios constantes das decisões dos Tribunais de Contas que julguem os responsáveis em alcance ou que lhes apliquem multa são caracterizados como dívida ativa não tributária.

Segundo Rodrigues (2009), os créditos contidos nas decisões condenatórias são dívidas ativas não tributárias e a execução de tais títulos extrajudiciais deve obedecer ao rito da LEF. Fernandes (2002 apud RODRIGUES, 2009, p. 70) afirma que a execução das decisões dos Tribunais de Contas tem o seu deslinde orientado pelas normas contidas na legislação especial extravagante (LEF), devendo-se retirar desta lei as diretrizes necessárias à propositura, desenvolvimento e finalização do referido procedimento judicial.

Ulisses Filho (2008) dá notícia de prática vigente na Comarca do Recife, segundo a qual as decisões condenatórias proferidas pelo TCE-PE eram ajuizadas pela Procuradoria 
Jurídica do Estado de Pernambuco nas Varas de Fazenda Pública, fundamentando a ação no rito das execuções por quantia certa previsto no art. 646 e seguintes do CPC. ${ }^{56}$

Em função do supratranscrito $\S 2^{\circ}$ do art. 39 da Lei $n^{\circ} 4.320$, de 1964 , o autor entende que tais execuções são de natureza fiscal, razão pela qual deveriam seguir o rito especial estabelecido pela LEF, com o consequente ajuizamento obrigatório em uma das Varas de Executivos Fiscais da Comarca do Recife.

$\mathrm{O}$ autor prossegue afirmando que a aplicação da referida lei especial é cogente com relação ao credor do crédito público, porquanto a LEF foi elaborada trazendo inovações, garantias e privilégios à Fazenda Pública, através de procedimento mais célere, racional e eficaz para a cobrança e garantia da arrecadação do dinheiro público, que é bem indisponível, não ficando portanto ao alvedrio do administrador escolher o procedimento de execução regido pelo CPC, posto que haveria prejuízo aos interesses da Fazenda Pública, considerando que esta ficaria privada de, em juízo, gozar das prerrogativas e privilégios processuais específicos garantidos na execução fiscal.

Uma aparente incongruência em tal raciocínio é o fato de as decisões dos Tribunais de Contas não necessitarem ser inscritas em dívida ativa, ou seja, a petição inicial muitas vezes não é instruída com a Certidão da Dívida Ativa, apesar de exigência nesse sentido contida no $\S 1^{\circ}$ do art. $6^{\circ}$ da LEF. ${ }^{57}$

Ocorre que a finalidade da inscrição em dívida ativa é garantir a liquidez e a certeza do crédito, conforme se depreende da leitura do art. $2^{\circ}, \S 3^{\circ}$, da LEF: "A inscrição, que se constitui no ato de controle administrativo da legalidade, será feita pelo órgão competente para apurar a liquidez e certeza do crédito [...]”.

Segundo Custódio (1991), a liquidez e a certeza são exigências de ordem processual que se harmonizam perfeitamente com o estabelecido no $\S 3^{\circ}$ do art. 71 da $\mathrm{CF}$. Para o autor, a atribuição de responsabilidade por solver um débito ou pagar uma multa implica a individuação do direito creditório do ente público em relação a alguém (certeza) e, em geral, a determinação do objeto ou prestação devida e, no mínimo, a determinabilidade do quantum debeatur (liquidez). ${ }^{58}$

56 Foge ao escopo deste trabalho verificar se a aludida prática ainda é seguida em Recife.

57 No âmbito federal, as decisões condenatórias envolvendo créditos da administração direta não são inscritas em dívida ativa. Por outro lado, os acórdãos envolvendo créditos da administração indireta são inscritos em dívida ativa. Para mais detalhes, consultar a nota de rodapé $\mathrm{n}^{\circ}$ 90, p. 76.

58 No mesmo sentido, Rosas (1981) afirma que as decisões dos Tribunais de Contas revestem-se de liquidez e certeza e, como tal, constituem título executivo para a cobrança judicial. 
De fato, conforme preceitua o art. 19 da Lei $\mathrm{n}^{\circ} 8.443 / 1992$ c/c o art. 215 do RITCU, as decisões em julgamentos de contas tornam a dívida líquida e certa, sendo o instrumento da condenação considerado título executivo para fundamentar a respectiva ação de execução judicial.

Custódio (1991) prossegue afirmando que as decisões dos Tribunais de Contas revestidas de liquidez e certeza não necessitam ser inscritas em dívida ativa para possibilitar, através de certidão, o ajuizamento do processo executório. Destarte, a LEF não pode ser invocada para fundamentar exigência nesse sentido, pois foi a própria CF que outorgou a eficácia de título executivo às decisões condenatórias proferidas pelas Cortes de Contas. Nada obstante isto, nada impediria que se procedesse à inscrição, para fins de controle de arrecadação, mas tal inscrição não é requisito essencial ao ajuizamento de execução fundada em tais títulos.

Nesse sentido, o Tribunal de Justiça do Estado de Minas Gerais - ao julgar agravo de instrumento em execução fiscal interposto pela Fazenda Pública estadual contra decisão que determinara a juntada aos autos do termo de inscrição em dívida ativa ou da certidão de dívida ativa referente a decisão proferida pelo TCE-MG - entendeu que o título representado pelo acórdão condenatório da Corte de Contas mineira reveste-se dos atributos da certeza, liquidez e exigibilidade, razão pela qual julgou desnecessária a inscrição em dívida ativa. Eis a ementa da decisão de segunda instância, in verbis:

\footnotetext{
EMENTA: AGRAVO DE INSTRUMENTO - EXECUÇÃO FISCAL DECISÃO DO TRIBUNAL DE CONTAS - TÍTULO EXECUTIVO EXTRAJUDICIAL - INTELIGÊNCIA DO ART. $71, \S 3^{\circ}$, DA CR/88. Toda execução deve se basear, de acordo com o que preceitua o art. 583, do Código de Processo Civil, em título executivo, o qual se caracterizará, segundo o art. 586, 'caput', do referido diploma, pelos atributos da certeza, liquidez e exigibilidade. De acordo com o artigo 585 do Código de Processo Civil, em seu inciso VII, são títulos executivos extrajudiciais, além daqueles enumerados pelo dispositivo legal, todos os demais que, por disposição expressa, a lei atribuir força executiva. Nesse sentido, a Constituição da República, através de seu art. $71, \S 3^{\circ}$, confere força de título executivo extrajudicial à simples certidão expedida pelo Tribunal de Contas que impute débito, não havendo necessidade de inscrição perante o livro da dívida ativa. (TJMG, 4 ${ }^{\mathrm{a}}$ Câmara Cível, AI 1.0686.07.192654-3/001. Relator: Des. Dárcio Lopardi Mendes. Julgamento em 02/08/2007. Publicado no DJ de 09/08/2007, grifos nossos).
}

Portanto, a partir do disposto no art. $2^{\circ}$ da LEF c/c o art. 39, § $2^{\circ}$, da Lei $n^{\circ} 4.320$, de 1964 , bem como em função do contido no art. $71, \S 3^{\circ}$, da CF, infere-se que o crédito da Fazenda Pública contido nas decisões condenatórias proferidas pelos Tribunais de Contas 
caracteriza-se como dívida ativa não tributária, razão pela qual o respectivo processo de execução judicial deve seguir o rito especial ${ }^{59}$ prescrito pela LEF, com a aplicação subsidiária das disposições do CPC, estando dispensada a inscrição em dívida ativa. ${ }^{60}$

Tal constatação implica que os embargos eventualmente opostos à execução de tais decisões só podem ser oferecidos após a garantia do juízo, o que traz uma perspectiva de maior efetividade na recuperação dos valores condenatórios do que haveria caso fosse seguido o rito comum dos títulos extrajudiciais em geral. ${ }^{61}$

Em princípio, a submissão à LEF também implicaria a aplicação, às decisões dos Tribunais de Contas, do disposto em seu art. 16 , $\S \S 2^{\circ}$ e $3^{\circ}$, que permite ao executado alegar, em sede de embargos à execução, toda matéria útil à defesa, à exceção da reconvenção e da compensação. Há que se ter em vista, contudo, a força executiva diferenciada de que se revestem os títulos condenatórios, conforme será abordado no item a seguir.

\subsection{Força executiva das decisões condenatórias}

A questão da força executiva ${ }^{62}$ das decisões condenatórias é tão tormentosa quando aquela que diz respeito à própria natureza jurídica de tais decisões. Em verdade, a primeira é corolário da segunda, ou seja, os doutrinadores que entendem que os julgamentos de contas não representam um exercício de jurisdição, mas sim mera atividade administrativa,

59 Segundo Ferraz (2003), a Lei Orgânica do Tribunal de Contas português submete a execução de suas decisões aos "Tribunais Tributários de primeira instância”, com aplicação do "processo de execução fiscal".

60 A posição pessoal do autor desta monografia é a submissão da cobrança judicial das decisões condenatórias ao rito executório da LEF, sem que haja a necessidade de prévia inscrição em dívida ativa. Nada obstante isto, a matéria é bastante controvertida, como se pode constatar no recente Acórdão no 1.603/2011- TCU Plenário, de relatoria do Ministro Ubiratan Aguiar. No Relatório desta decisão, elencam-se vários entendimentos jurisprudenciais favoráveis e contrários à submissão da cobrança judicial em comento ao rito da LEF. Aborda-se ainda linha doutrinária que entende possíveis tanto a aplicação do rito da execução de títulos extrajudiciais prevista no CPC (execução por quantia certa) quanto a aplicabilidade do rito da execução fiscal, desde que, neste último caso, haja a prévia inscrição em dívida ativa.

No Voto do aludido Acórdão, menciona-se que "não há como superar a ausência de norma legal que não deixe dúvidas sobre qual o rito a ser observado quando da execução de acórdão do TCU, bem como regulamente a sistemática relativa à inscrição em Dívida Ativa não Tributária".

61 Nos termos do Relatório do suprarreferido Acórdão no 1.603/2011 - TCU - Plenário, "De lege ferenda, não se nega as diversas facilidades agregadas pelo regime da Lei de Execução Fiscal (Lei n 6.830/1980). Entretanto, considera-se que a extensão dessas prerrogativas deve-se dar por meio de alteração legal, não para estabelecer a necessidade de inscrição dos acórdãos do TCU em dívida ativa (norma que se entenderia por inconstitucional), mas sim para estabelecer que o rito aplicável à execução dessas deliberações é o rito da execução fiscal [...]".

62 Segundo o glossário da Rede Judiciária Europeia em materia civil e comercial (COMISSÃO EUROPEIA, 2011), força executiva é uma noção própria do direito processual civil, segundo a qual as decisões judiciais têm força executiva na medida em que podem ser efetivamente executadas, recorrendo-se, se necessário, à força pública. Entende-se que, quanto menor a expectativa na obtenção do crédito e maior a possibilidade de defesa na execução judicial, menor será a força executiva do título. 
não reconhecem a tais decisões a formação de coisa julgada ${ }^{63}$, razão pela qual, em geral, tal corrente entende que os acórdãos condenatórios possuem a mesma força executiva dos títulos extrajudiciais arrolados no art. 585 do CPC. Assim sendo, seria possível ao executado alegar qualquer matéria que lhe seria lícito deduzir como defesa no processo de conhecimento, conforme preceitua o art. 745, V, do CPC.

Segundo Ferraz (1999), por exemplo, dependendo da natureza do título no qual se funde a ação de execução judicial, o legislador admitia maior ou menor espectro probandi aos embargos do devedor. Assim, os embargos do devedor fundados em títulos judiciais ${ }^{64}$ tinham limitadas possibilidades de prova, basicamente relacionadas a matérias atinentes à forma e não propriamente ao mérito. Por outro lado, os embargos fundados em títulos extrajudiciais admitem a alegação, pelo devedor, de qualquer outra matéria que lhe seria lícito deduzir como defesa no processo de conhecimento, podendo o executado fazer prova inclusive contra a existência ou não do débito.

Por outro lado, aqueles autores que defendem os julgamentos de contas como autêntico exercício da jurisdição estatal entendem que tais decisões formam coisa julgada, sendo admitida a revisão, pelo Poder Judiciário, apenas no que se refere a aspectos formais, relativos à legalidade do procedimento e ao respeito ao devido processo legal, sem adentrar o mérito do julgamento de contas, que é de competência exclusiva dos Tribunais de Contas. Tais doutrinadores reconhecem às decisões condenatórias maior força executiva que aquela conferida aos títulos extrajudiciais em geral.

$\mathrm{Na}$ corrente dos que reconhecem aos Tribunais de Contas o exercício da jurisdição, há basicamente duas linhas: aquela que propugna pela inclusão dos acórdãos condenatórios no rol dos títulos executivos judiciais (art. 475-N do CPC), a exemplo de Martinez (2006); a que enquadra tais decisões como títulos executivos extrajudiciais sui generis, porquanto dotados de maior força executiva que os demais títulos extrajudiciais, a exemplo de Costa Júnior (2001). Nesta segunda linha, há quem defenda que o procedimento de execução de tais títulos deve obedecer às disposições da LEF, a exemplo de Ulisses Filho (2008).

63 Quando muito, tais doutrinadores, , a exemplo de Di Pietro (1996), entendem haver tão-somente a formação de coisa julgada administrativa, razão pela qual estaria a decisão sujeita a revisão plena pelo Poder Judiciário.

64 Os embargos do devedor fundados em título executivo judicial foram extintos por reforma processual operada em 2005. De acordo com o CPC em vigor, a execução judicial ocorre como uma fase no âmbito do próprio processo do qual emanou o título (fase de cumprimento de sentença), podendo o executado opor impugnação (art. 475-J, $\S 1^{\circ}$, do CPC) e não mais embargos. 
No presente trabalho, conforme justificado alhures, defende-se a submissão do rito processual executivo das decisões condenatórias às disposições da LEF e discorda-se da tentativa de incluir tais decisões no rol de títulos executivos judiciais. Independentemente da linha adotada, contudo, forçoso é reconhecer que não se pode conferir a tais decisões a mesma força executiva atribuída aos títulos extrajudiciais elencados no art. 585 do CPC, pelas razões a seguir expostas. $^{65}$

Nos termos do art. 745 do CPC, diante da execução de um título extrajudicial, o executado pode alegar uma vasta gama de matérias, haja vista o disposto no citado inciso $\mathrm{V}$ do referido artigo, que permite ao executado alegar "qualquer matéria que lhe seria lícito deduzir como defesa em processo de conhecimento".

Segundo Marinoni (2008), em função de os títulos extrajudiciais não gozarem das mesmas garantias dos títulos judiciais, não tendo sido formados com atenção às garantias básicas do processo, o rito utilizado para permitir sua execução não segue os mesmos padrões que orientam a execução de títulos judiciais, havendo variações significativas de procedimento visando a proteger o suposto devedor contra uma execução injusta.

Ainda segundo o mesmo autor, enquanto as execuções de títulos judiciais dispensam, via de regra, a criação de novo processo, ocorrendo no bojo do próprio processo do qual emanou o título, a execução de título extrajudicial sempre faz surgir processo novo. $\mathrm{O}$ autor chega a afirmar (grifo nosso):

[..] como nada há de jurisdicional na formação do título extrajudicial, o procedimento destinado a sua execução abre oportunidade para o executado apresentar ação incidental de conhecimento (chamada de embargos do executado), onde as matérias alegáveis não são restritas pela lei, como acontece com a impugnação, em que apenas podem ser invocados os fundamentos elencados nos incisos do art. 475-L. [...] Este processo de conhecimento incidente ao de execução é de cognição plena e exauriente.

Obviamente, a descrição acima está longe de se aplicar aos títulos executivos extrajudiciais representados pelos acórdãos condenatórios. Estes são prolatados após terem sido garantidos ao devedor o contraditório e a ampla defesa, inclusive mediante a aplicação do princípio do formalismo moderado e a possibilidade da interposição de recursos no âmbito dos próprios Tribunais de Contas (ver itens 1.5.1 a 1.5.4).

65 Embora a certidão de dívida ativa encontre-se arrolada no inciso VII do art. 585 do CPC, entende-se que sua força executiva não se equipara a dos demais títulos relacionados neste artigo, em virtude de sua submissão ao regime da Lei ${ }^{\circ} 6.830$, de 1980. 
Segundo Costa Júnior (2001), se a lide posta diante do Tribunal de Contas foi submetida ao crivo do contraditório e da ampla defesa e foi solucionada por meio de um ato típico de jurisdição, os limites à revisibilidade judicial - mencionados no item 2.2 do presente trabalho - são válidos também para os embargos à execução das decisões condenatórias, por uma questão de coerência lógica. Se o Poder Judiciário não pode adentrar o mérito da decisão no bojo do processo de conhecimento, não há razão para que pudesse fazê-lo quando do exame dos embargos à execução, inclusive porque estes possuem natureza jurídica cognitiva.

$\mathrm{O}$ autor conclui seu raciocínio afirmando que o revogado art. 745 do CPC praticamente reproduzido pelo inciso $\mathrm{V}$ do novo art. 745 , com redação dada pela Lei $\mathrm{n}^{\circ}$ 11.382, de 2006 -, cuja redação datava de 1973, não teria sido recepcionado ${ }^{66}$ pela CF no que diz respeito àqueles formados com base em uma decisão condenatória do Tribunal de Contas, proferida em um processo no qual o órgão tivesse exercido atividade jurisdicional.

Bugarin (2004) dá notícia de que as decisões condenatórias do TCU têm sido objeto de diversos questionamentos no âmbito do primeiro grau de jurisdição, no decorrer dos processos de execução, por intermédio dos embargos do devedor, com o objetivo, em regra, de atacar o mérito do julgamento de contas. Mencionam-se ainda os constantes questionamentos às decisões do TCU, também na primeira instância, por intermédio de ações declaratórias de nulidade.

De fato, revela-se assaz inadequada a revisão, por juiz singular, de decisões proferidas por colegiado de julgadores ${ }^{67}$. Nesse sentido, Bento Bugarin (2000 apud BUGARIN, 2004, p. 83) assim se manifestou acerca da discussão, na primeira instância, das decisões proferidas pelo TCU:

A situação é, no mínimo, esdrúxula, pois não é razoável aceitar que decisões da Corte de Contas sejam discutidas no primeiro grau de jurisdição, quando a própria Constituição previu prerrogativa de foro para a discussão de decisões da Corte de Contas.

66 Considerando que o inciso V do art. 745 praticamente reproduziu a redação originária do revogado art. 745, e tendo em vista que o novo dispositivo foi inserido em 2005 (posteriormente à Constituição de 1988), deve-se conferir ao novo dispositivo interpretação conforme a Constituição, para não entendê-lo aplicável às execuções de decisões dos Tribunais de Contas.

67 Convém lembrar que o art. 73, $\S 3^{\circ}$, atribui aos Ministros do TCU as mesmas garantias, prerrogativas, impedimentos, vencimentos e vantagens dos Ministros do STJ. Além disso, o art. 73, $\S 4^{\circ}$, do mesmo artigo confere aos Auditores do TCU (Ministros-Substitutos) as mesmas garantias e impedimentos do titular e, "quando no exercício das demais atribuições da judicatura, as de juiz de Tribunal Regional Federal” (grifo nosso). 
A prerrogativa de foro mencionada no supratranscrito excerto é aquela contida no art. 102, I, "d", da CF, segundo a qual compete ao STF processar e julgar o mandado de segurança contra atos do TCU. A esse respeito, Affonso (1996 apud BUGARIN, 2004, p. 84) assevera:

[...] a despeito de haver a atual Constituição estabelecido uma ampliada gama de competências, próprias e privativas das Cortes de Contas (arts. 70, 71 e 75), sabe-se que as suas deliberações, em última análise, podem acabar sendo obstaculizadas, por alguma modalidade de decisão judicial, seja atacando-as na sua fonte geradora, pelo mandado de segurança, seja neutralizando os seus efeitos, pelos embargos à execução das suas condenações. No caso do uso de ação mandamental, a prerrogativa de função do órgão confere foro privilegiado, o que assegura maior dose de equilíbrio, mas nos demais casos, podem ficar na dependência de decisão monocrática de juízos do primeiro grau de jurisdição, o que causa uma aparente subversão na ordem hierárquica de valores.

A partir de tais excertos e contrariamente ao posicionamento de Ferraz (1999) que confere às decisões condenatórias a mesma força que detêm os títulos extrajudiciais em geral -, Bugarin (2004) destaca a marcante diferença entre o título consubstanciado no acórdão condenatório do Tribunal de Contas e todos os demais títulos executivos extrajudiciais. O autor afirma que o processo administrativo no âmbito dos Tribunais de Contas, nada obstante ser informado pela busca da verdade real e pela prevalência do formalismo moderado (ver itens 1.5.2 e 1.5.3), segue, do ponto de vista instrumental, os mesmos princípios processualísticos do processo judicial, sendo sempre garantida aos responsáveis ou interessados a ampla defesa, nos termos do devido processo legal. Assim, na jurisdição especial de contas, ocorre verdadeiro processo de conhecimento de competência privativa dos órgãos de controle externo ${ }^{68}$.

Em verdade, a qualificação das decisões condenatórias como meros títulos executivos extrajudiciais para todos os fins previstos na legislação processual revela um verdadeiro desconhecimento da processualística adotada pelos Tribunais de Contas no exercício da jurisdição especial de contas (BUGARIN, 2004).

Martinez (2006) revela o absurdo que ocorre, por exemplo, em uma tomada de contas especial. Tal processo é constituído após investigação que identifica o responsável e apura o montante do valor desviado, sendo encaminhado para julgamento pelo Tribunal de

68 Segundo Chaves (2009), a decisão do Tribunal de Contas que impute débito ou comine multa equivale a uma decisão de mérito no juízo de conhecimento feito por órgão judiciário, ou seja, a cognição de mérito é feita pela Corte de Contas. 
Contas. Este órgão cita o responsável, que dispõe de uma ampla gama de instrumentos processuais para sua defesa no âmbito da própria Corte de Contas, podendo inclusive interpor recursos, como os embargos de declaração, o recurso de reconsideração e o recurso de revisão, nos termos da LOTCU.

Prossegue o autor em seu relato hipotético: após o trânsito em julgado da decisão definitiva, o acórdão resultante é título executivo líquido e certo, sendo encaminhado ao órgão competente para que seja ajuizada a ação de execução judicial. Superado todo o processo de conhecimento perante o Tribunal de Contas, o executado vem a questionar novamente a decisão condenatória, agora perante a primeira instância do Poder Judiciário, pretendendo alegar qualquer matéria, como se estivesse diante de um processo original de conhecimento, por meio dos embargos à execução.

Tal amplitude de matérias sujeitas a alegação pelo executado praticamente iguala a força executiva do acórdão condenatório a um mero cheque, o que compromete toda efetividade da condenação imposta ao responsável pelo Tribunal de Contas (MARTINEZ, 2006). ${ }^{69}$

Segundo La Rocque Almeida (2004), embora a decisão condenatória do Tribunal de Contas seja um título executivo extrajudicial, eventuais embargos à execução não poderão versar sobre qualquer matéria de defesa que seria lícito ao devedor alegar no processo de conhecimento, apesar de o art. 745 do CPC dispor neste sentido. Para o autor, tal entendimento é coerente com a sistemática segundo a qual ao Poder Judiciário só é permitido reformar a decisão condenatória quando haja ilegalidade manifesta ou preterição de formalidade legal, o que não representa prejuízo à defesa do executado, pois a este já foram conferidos o contraditório e a ampla defesa por ocasião do próprio julgamento de contas.

$\mathrm{Na}$ mesma linha de tal entendimento, Zymler e La Rocque Almeida (2008) defendem que os embargos à execução não poderão versar sobre todas as matérias que seria lícito ao devedor deduzir em um processo de conhecimento, apesar do que preceitua o art. 745 do CPC. A justificativa para tal entendimento é a impossibilidade da discussão do mérito do título nos embargos à execução, ressalvada a ocorrência de ilegalidade manifesta ou preterição de formalidade legal.

Assim, nada obstante as decisões condenatórias proferidas pelos Tribunais de Contas serem títulos extrajudiciais em função de tais órgãos não pertencerem ao Poder

\footnotetext{
69 Remete-se o leitor à nota de rodapé no 51, p. 53-54.
} 
Judiciário, o mérito do julgamento não pode ser modificado por este Poder, seja em sede de processo de conhecimento, seja por meio de embargos à execução.

Processualmente, a execução de tais títulos deve seguir os preceitos da LEF, já que o crédito neles contido é dívida ativa da Fazenda Pública. Em que pese isto, somente podem ser alegadas, nos embargos à execução, matérias atinentes a eventual ilegalidade manifesta ou irregularidade formal, haja vista a jurisdição constitucional de contas estabelecida pelo inciso II do art. 71 da CF e a garantia do contraditório e da ampla defesa no processo de contas.

\subsection{A questão da efetividade na recuperação judicial dos valores condenatórios}

Questão de suma importância diz respeito à efetividade na recuperação dos valores constantes das decisões condenatórias proferidas pelos Tribunais de Contas uma vez ajuizados os respectivos processos de execução. A rigor, os dados a esse respeito divergem bastante $e^{70}$.

Martinez (2006), por exemplo, afirma que o índice histórico de recuperação de valores desviados, na fase judicial de cobrança, girava em torno de $0,5 \%$ a $1 \%$ do montante das condenações impostas pelo $\mathrm{TCU}^{71}$. Matéria publicada no último ano (CERCO, 2010) dá notícia de que, há 15 anos, o índice de recuperação judicial dos valores seria de $0,5 \%$; há 10 anos, de 1,5\%; e há cinco anos não passaria dos $2 \%$. No ano de 2009, segundo a aludida matéria, tendo em vista parceria firmada entre o TCU e a AGU, o índice teria alcançado o patamar de $10 \%$, ainda bastante baixo.

Sobre a questão da efetividade, Miola (2011) afirma (grifo nosso):

Destarte, não obstante sejam estes Entes, Tribunais de Contas, os eleitos para apreciar e julgar as contas de administradores públicos e demais responsáveis pelo manuseio de recursos públicos - até mesmo podendo determinar-lhes ressarcimentos ao Erário e aplicar-lhes sanções pecuniárias (art. 71, II e VIII, da Constituição da República) - e mesmo tendo presente a notável força atribuída a essa espécie de decisões (têm eficácia de título executivo, quando houver fixação de débito ou imposição de multa, na dicção do $\S 3^{\circ}$ do mesmo artigo 71 , antes citado), os resultados práticos dessa atuação vêm se mostrando absolutamente débeis.

70 A efetividade na recuperação judicial dos valores condenatórios diz respeito à relação entre os valores efetivamente recuperados a benefício do Erário Público e os valores ajuizados em processos de execução judicial. Não faz parte do escopo desta monografia quantificar ou estabelecer um método para calcular o índice de recuperação judicial dos valores condenatórios.

71 O autor chega a tal constatação a partir do Relatório de Atividades do TCU referente ao exercício de 1999. 
De acordo com o Relatório Anual de Atividades do TCU referente ao exercício de 2010 (TCU, 2010a), dos 3.269 processos de contas $^{72}$ apreciados de forma conclusiva pelo TCU no ano, 1.517 processos $(46,40 \%)^{73}$ resultaram na condenação de 2.450 responsáveis ao ressarcimento de débito e/ou ao pagamento de multa ${ }^{74,75}$. O total de débitos imputados e de multas cominadas em processos de contas alcançou, no exercício de 2010, o patamar de $\mathrm{R} \$$ 1,46 bilhão ${ }^{76}$.

Ainda de acordo com o citado Relatório Anual de Atividades do TCU, o MP/TCU promoveu, por intermédio da AGU ou, conforme o caso, perante os dirigentes das entidades jurisdicionadas do Tribunal, as medidas necessárias à execução judicial de débitos ou multas decorrentes de acórdãos condenatórios proferidos pelo TCU, havendo sido submetidos 2.438 processos de cobrança executiva a tais órgãos de execução, com vistas ao ajuizamento das respectivas ações judiciais de cobrança. Os débitos e multas constantes dos acórdãos condenatórios remetidos aos órgãos de execução totalizaram o valor de R \$ 1,42 bilhão, sendo que, deste valor, aproximadamente $\mathrm{R} \$ 1,37$ bilhão referem-se à imputação de débitos e $\mathrm{R} \$ 50$ milhões à cominação de multas.

De acordo com relatório do Grupo Permanente de Atuação Pró-Ativa (AGU, 2010), no período de novembro de 2009 a dezembro de 2010, a PGU/AGU ${ }^{77}$ ingressou com 2.147 ações baseadas em decisões condenatórias proferidas pelo TCU, abrangendo o valor total de R\$ 528.962.260,34 ${ }^{78}$. No mesmo período, ainda de acordo com o citado relatório da AGU, foram recolhidos aproximadamente $\mathrm{R} \$ 491,2$ milhões relativos a débitos resultantes de

72 Os processos de contas abrangem as prestações de contas, as tomadas de contas e as tomadas de contas especiais.

73 A maior parte das condenações adveio de tomadas de contas especiais (1.391 processos). As motivações para o julgamento pela irregularidade das contas foram, em ordem decrescente: a) dano ao erário decorrente de ato de gestão ilegítimo ou antieconômico $(37,54 \%)$; b) prática de ato de gestão ilegal ou infração a norma legal $(36,83 \%)$; c) desfalque ou desvio de dinheiro, bens ou valores públicos $(15,45 \%)$; e omissão no dever de prestar contas $(10,18 \%)$.

74 A aplicação de multas ocorre não só em processos de contas, mas também em processos de fiscalização. Nesse sentido, foram aplicadas multas em 195 processos de fiscalização no exercício de 2010, com a condenação de 435 responsáveis.

75 Um processo de contas pode conter mais de um responsável cujas contas serão julgadas.

76 Valores atualizados até a data de 31/12/2010. Também é possível a aplicação de multas em processos de fiscalização, as quais totalizaram, no exercício de 2010, o montante de R \$ 4,5 milhões.

77 Conforme o Relatório de Gestão do TCU referente ao exercício de 2009 (TCU, 2009), dos 3.071 processos administrativos de cobrança executiva remetidos aos órgãos executores no ano, 2.483 foram encaminhados à PGU/AGU para a competente execução judicial, o que representa mais de $80 \%$ do universo de processos.

78 Tal valor representa o que foi ajuizado e não o que foi recuperado. O período de apuração (novembro de 2009 a dezembro de 2010) não corresponde exatamente àquele do Relatório de Atividades (TCU, 2010a). 
convênios, o que representa - considerando exclusivamente uma análise de fluxo - um percentual de quase $93 \%$ do que foi demandado (TCU, 2010b). ${ }^{79}$

Destarte, as somas envolvidas na atividade judicante do TCU atingem patamar bastante elevado, o que justifica a reflexão sobre alternativas aptas a otimizar os procedimentos envolvidos na execução judicial dos títulos condenatórios, com o que se vislumbra um potencial ganho de efetividade.

Ademais, o ganho de efetividade permite benefícios outros que não os exclusivamente monetários, contribuindo para a cessação da impunidade, do arbítrio, da liberalidade com os recursos públicos e da improbidade administrativa, condutas que se servem, via de regra, da comodidade, da inércia, da passividade e do próprio comprometimento daqueles que têm por dever funcional combater tais práticas perniciosas (MIOLA, 2011).

\subsubsection{Medidas prévias à decisão condenatória definitiva}

A efetividade na recuperação judicial dos valores condenatórios depende de uma série de fatores, entre os quais se encontram aspectos processuais presentes no próprio processo de contas, mesmo que o acórdão condenatório não tenha ainda sido proferido.

O art. 61 da LOTCU prevê a possibilidade de o Tribunal, por intermédio do MP/TCU, requerer à AGU (no caso de débitos imputados a responsáveis da Administração Direta) ou aos dirigentes das entidades que lhe sejam jurisdicionadas (no caso de débitos imputados a responsáveis por entidades da Administração Indireta) a adoção das medidas necessárias ao arresto dos bens dos responsáveis julgados em débito ${ }^{80}$, devendo o Tribunal ser ouvido quanto à liberação dos bens arrestados e sua restituição. ${ }^{81}$

Para Jacoby Fernandes (2008), conquanto a aludida previsão legal tenha o seu valor, a iniciativa é tímida, porquanto prevista somente após a conclusão do processo

79 Ademais, no mesmo período, foram obtidos em garantia R\$ 582.661.579,60 (AGU, 2010). Somando-se os valores arrecadados e os obtidos em garantia, o montante total supera o percentual de $207 \%$ dos valores condenatórios ajuizados no ano de 2010 (TCU, 2010b). De acordo com o Relatório de Cobrança Executiva (TCU, 2010b), os dados significativos do relatório do Grupo Permanente de Atuação Pró-Ativa da Procuradoria-Geral da União - PGU (AGU, 2010) denotam zelo e proficuidade na condução dos trabalhos de cobrança executiva. Ressalta-se, neste particular, a presença de escritório de representação da PGU/AGU no Tribunal e o Acordo de Cooperação Técnica firmado entre os órgãos em 2009. A PGU é responsável pela execução de acórdãos condenatórios envolvendo órgãos da administração direta (nota de rodapé $\mathrm{n}^{\circ}$ 90, p. 76).

80 A norma não prevê a possibilidade de arresto para multas.

81 A LOTCU prevê ainda, em seu art. $44, \S 2^{\circ}$, a possibilidade de o TCU decretar, por prazo não superior a um ano, a indisponibilidade de bens do responsável, tantos quantos considerados bastantes para garantir o ressarcimento dos danos em apuração. 
administrativo de julgamento de contas. Um bom avanço seria instituir a possibilidade de o Tribunal requerer o arresto diretamente ao Poder Judiciário ou por intermédio do Ministério MP/TCU antes do término do julgamento das contas, desde que presente a liquidez do débito, em havendo justo receio de que o julgamento se torne ineficaz pelo decurso de tempo. ${ }^{82}$

Mas a questão do arresto não é o único fator que contribui para uma menor efetividade na recuperação judicial dos valores condenatórios. Outra causa bastante relevante é a própria questão da tempestividade, de vez que há inúmeros convênios e instrumentos congêneres celebrados pela União com repasse de recursos públicos federais para Municípios e instituições não-governamentais, cujas prestações de contas ficam aguardando apreciação nos respectivos Ministérios durante amplo lapso temporal, tendo em vista, entre outros fatores, a falta de pessoal para tal análise. Outras prestações não são sequer formalizadas pelos entes recebedores dos recursos, dando azo à instauração de tomada de contas especial.

Quando prestações de contas com pendências ou mesmo tomadas de contas especiais são submetidas ao julgamento do TCU, já decorreu bastante tempo desde que os atos de gestão ilegais, ilegítimos ou antieconômicos foram praticados e os responsáveis já tiveram a oportunidade de adotar medidas com vistas a não deixar patrimônio próprio passível de penhora. Há que se ter, portanto, uma atuação mais tempestiva ${ }^{83}$, caso contrário a recuperação judicial dos valores condenatórios, por óbvio, ficará bastante comprometida.

Segundo o Acórdão-TCU no 3025/2010 - Plenário, de relatoria do Ministro Raimundo Carreiro, há deficiências materiais, humanas e tecnológicas nos órgãos repassadores, como controles inexistentes ou ineficientes, mecanismos de transparência insuficientes, ausência ou deficiência nos sistemas informatizados e falta de servidores habilitados para analisar e fiscalizar a descentralização dos recursos em número compatível com o volume de instrumentos celebrados. Ainda de acordo com o Relatório do aludido Acórdão, há um grande passivo de prestações de contas não analisadas, com mais de 50 mil processos de prestações de contas envolvendo recursos federais da ordem de R \$ 19,6 bilhões. O controle de tais prestações é a posteriori, dado que há um enorme estoque com idade média

82 Uma alternativa ainda mais ousada seria permitir que, diante de fortes indícios de desvio de recursos públicos, a Controladoria-Geral da União (CGU) pudesse acionar a AGU visando ao arresto dos bens antes mesmo que o processo de tomada de contas especial fosse encaminhado ao TCU.

83 Importante consignar que, uma vez encaminhadas as contas ao TCU, os respectivos processos são submetidos à instrução da unidade técnica responsável, à manifestação do MP/TCU, ao Gabinete do Ministro-Relator e, finalmente, ao julgamento por colegiado de Ministros. Obviamente, tal trâmite interno leva certo tempo, em que pese a maior celeridade conferida pelo processo eletrônico de controle externo (eTCU), implantado no ano de 2010. 
superior a cinco anos, o que alimenta "um ciclo vicioso de baixa efetividade de 'autópsias de desperdício de recursos públicos" ".

Especificamente no que tange às prestações de contas - ou à falta delas - de prefeitos cujos Municípios tenham recebido recursos públicos federais mediante convênio, segundo Mendonça (informação verbal) ${ }^{84}$, cerca de $60 \%$ das ações ajuizadas pela AGU, cujo objeto seja a má aplicação ou o desvio de recursos públicos, têm como réus prefeitos ${ }^{85}$. Para La Rocque Almeida (informação verbal) ${ }^{86}$, grande parte das falhas nas prestações de contas deve-se ao despreparo dos gestores ${ }^{87}$, razão pela qual há que se considerar, nos julgamentos de contas, a estrutura da prefeitura e a existência de eventuais atenuantes para as falhas na gestão dos recursos públicos.

Como consequência do grande intervalo de tempo que se passa entre a prestação de contas pelo gestor de recursos públicos ao Ministério repassador e o seu julgamento definitivo pelo TCU, faz-se mister mencionar a dificuldade em se promover a citação e/ou a notificação dos responsáveis por contas julgadas irregulares. Nesse sentido, não é rara a impossibilidade de se localizar o executado para fins de notificação da decisão condenatória proferida, por exemplo, em processo de tomada de contas especial ${ }^{88}$. Uma possível alternativa para tal problema seria a previsão legal da possibilidade de a notificação ser realizada em meio eletrônico.

\subsubsection{Algumas alternativas previstas na legislação processual civil}

A reforma processual operada pela Lei $\mathrm{n}^{\circ} 11.382$, de 2006 , estabeleceu inovações procedimentais aptas a aumentar a efetividade na recuperação judicial dos valores condenatórios, de que são exemplos a averbação da execução a partir de certidão de

84 Palestra proferida em 09/06/2011 por André Luiz de Almeida Mendonça, Diretor do Departamento de Patrimônio Público e Probidade Administrativa da AGU, por ocasião do II Seminário Nacional de Fiscalização e Controle de Recursos Públicos, realizado na Câmara dos Deputados.

85 Não é por acaso que Minas Gerais, o Estado com o maior número de Municípios, é a unidade da federação que contabilizou maior quantitativo de processos de cobrança executiva autuados no ano de 2010 (TCU, 2010d). Sobre processos de cobrança executiva, consultar o item 3.5.

86 Palestra proferida em 09/06/2011 por Guilherme Henrique de La Rocque Almeida, Secretário-Geral de Controle Externo do TCU, por ocasião do II Seminário Nacional de Fiscalização e Controle de Recursos Públicos, realizado na Câmara dos Deputados.

87 Por essa razão, o Instituto Serzedello Corrêa (ISC), unidade de educação corporativa do TCU, tem capacitado, desde 2009, milhares de gestores públicos estaduais e municipais por intermédio de cursos a distância, realizados online no Portal TCU. Entre os cursos ofertados, encontra-se o de "Prestação de Contas de Convênios".

88 Uma medida recomendável é que conste do instrumento de convênio o local em que o prefeito pode ser encontrado. 
ajuizamento, a rejeição liminar dos embargos manifestamente protelatórios e a penhora online.

Com a inclusão do art. 615-A no CPC, tornou-se possível ao exequente, no ato da distribuição, obter certidão comprobatória do ajuizamento da execução, com identificação das partes e valor da causa, para fins de averbação no registro de imóveis, registro de veículos ou registro de outros bens sujeitos à penhora ou arresto.

Segundo Vieira e Lorencini (2007), a averbação da execução junto aos órgãos competentes tem o escopo de promover a publicidade da ação com relação aos bens do executado que sejam passíveis de penhora, com o intuito de se evitar alegações futuras de que esses mesmos bens tenham sido adquiridos por terceiros de boa-fé. Para os autores, tal averbação é providência a ser efetivada pelo próprio exequente e em seu interesse, sem maiores formalidades, sendo de sua inteira responsabilidade o adiantamento das custas e despesas para sua efetivação, bem como é ele quem responde por eventual má-fé no pedido de averbação.

Nesse sentido, é desejável que os órgãos executores das decisões condenatórias proferidas pelos Tribunais de Contas procedam à averbação das ações de execução junto aos órgãos competentes, pois isso permitirá uma maior garantia ao Erário na futura efetivação da penhora sobre os bens do executado. Para Vieira e Lorencini (2007), a averbação possibilitada pelo art. 615-A do CPC tem nítido caráter cautelar, cabendo ressaltar que a eventual alienação ou oneração de bens efetuada após a averbação caracteriza-se como fraude à execução (art. 615-A, § $3^{\circ}$, do CPC).

No que se refere à rejeição liminar dos embargos, encontra-se esta prevista no art. 739 do CPC. Os embargos podem ser rejeitados liminarmente quando intempestivos, quando inepta a petição ou quando manifestamente protelatórios. Segundo Giannico e Monteiro (2007), esta última hipótese não deveria ser um requisito de admissibilidade dos embargos, pois não inquinaria de irregularidade a relação processual do ponto de vista formal. Em que pese isto, fato é que o legislador ordinário previu que os embargos manifestamente protelatórios justificam a inadmissibilidade da ação, razão pela qual os órgãos responsáveis pela execução judicial das decisões condenatórias - diante de manifesto intuito protelatório do embargante - devem alegar tal circunstância, sempre que for o caso.

Já no que diz respeito à penhora online, o art. 655-A do CPC permite ao juiz, a requerimento da parte, requisitar à autoridade supervisora do sistema bancário, preferencialmente por meio eletrônico, informações sobre a existência de ativos em nome do 
executado, podendo no mesmo ato determinar sua indisponibilidade, até o valor indicado na execução.

$\mathrm{Na}$ verdade, em que pese o fato de a penhora online já existir como prática antes da reforma processual de 2006, o art. 655-A formalizou tal prática, o que agilizou substancialmente a satisfação das obrigações baseadas em títulos extrajudiciais (SACCO NETO, 2007 apud VIEIRA E LORENCINI, 2007, p. 62), tendo em vista inclusive a nova redação do inciso I do art. 655 do CPC, que colocou o dinheiro em primeiro lugar na ordem de preferência, seja em espécie, seja em depósito ou aplicação em instituição financeira (VIEIRA E LORENCINI, 2007).

Aliás, no que toca à penhora, sua substituição não se rege pelo art. 656 do CPC, mas sim pelo disposto no art. 15 da LEF, podendo o executado requerer a substituição da penhora por depósito em dinheiro ou fiança bancária. Já a Fazenda Pública pode requerer "a substituição dos bens penhorados por outros, independentemente da ordem prevista no art. 11 da LEF, bem como o reforço da penhora insuficiente”. Impõe-se que a Fazenda Pública, contudo, fundamente seu pedido em algum dos incisos do art. 656 do $\mathrm{CPC}$, à exceção, por óbvio, do inciso I, que justifica o pedido de substituição da penhora caso esta não tenha obedecido à ordem legal (CUNHA, 2007).

Feita a penhora, a alienação na execução fiscal só poderá ser realizada por meio de leilão público, tendo em vista a exigência constante do art. 23 da LEF, ressalvado o direito de a própria Fazenda Pública adjudicar o bem, nos termos do art. 24 da própria LEF. Não se aplica, portanto, à execução fiscal, a alienação por iniciativa particular prevista no art. 685-C do CPC, incluído pela Lei no 11.382, de 2006.

Conforme mencionado no item 3.1.3 do presente capítulo, na execução judicial de títulos condenatórios enquadráveis como dívida ativa da União, suas autarquias e fundações públicas, o exequente pode indicar bens à penhora, a qual será efetivada concomitantemente à citação inicial do devedor, com a consequente indisponibilidade dos bens. Trata-se de dispositivo legal que deve ser utilizado pelos órgãos executores federais, mas que, lamentavelmente, não pode ser aplicado à execução judicial dos acórdãos dos TCEs e TCMs, por ausência de expressa previsão legal.

\subsubsection{Estratégias para defesa da jurisdição constitucional de contas}

Consoante abordado no item 2.2 desta monografia, as decisões condenatórias definitivas proferidas pelos Tribunais de Contas fazem coisa julgada, carecendo de 
competência o Poder Judiciário para reformá-las, ressalvados aspectos extrínsecos ao julgamento, como eventual ilegalidade manifesta ou desrespeito ao devido processo legal.

Jacoby Fernandes (2008), de forma extremamente didática, analisa as hipóteses mais comuns em processos judiciais as quais têm como pano de fundo a discussão do mérito do julgamento dos Tribunais de Contas. $\mathrm{O}$ autor formula quatro hipóteses, com as respectivas medidas cabíveis:

a) O autor de uma ação busca inibir os efeitos de processo em tramitação no Tribunal de Contas, ainda não julgado definitivamente: sugere-se demonstrar em juízo, por petição, a competência constitucional do julgamento de contas; requerer a suspensão do processo, com esteio no art. 265, IV, “a”, do CPC;

b) O servidor responsabilizado busca desconstituir judicialmente a decisão do Tribunal de Contas, por suposta ofensa ao devido processo legal: trata-se da hipótese mais frequente. Caso o autor pretenda discutir o mérito da questão, deve-se alegar a existência de coisa julgada, bem como a competência constitucional do julgamento de contas; se a ação escolhida pelo autor for o mandado de segurança, o processo não deve ter seguimento se pretender discutir o mérito, pois tal via processual não admite produção probatória em juízo;

c) Réu opõe-se à execução judicial alegando que o julgamento do Tribunal de Contas não prevalece no Poder Judiciário: a parte deve garantir o juízo, observado o disposto no art. $8^{\circ}$ da LEF, para se opor à execução por meio de embargos; o órgão executor deve adotar o procedimento da exceção, que corre em apenso aos autos principais, nos termos do art. 299 do CPC, para arguir a existência de coisa julgada, visando prevalecer a eficácia do julgamento de contas, requerendo-se a extinção do processo sem julgamento do mérito, na forma do art. 267, V, do CPC;

d) Réu opõe-se à execução judicial apresentando embargos infringentes: nos termos do art. 530 do CPC, tal recurso cabe, no processo civil, em casos de acórdãos não unânimes que tenham reformado, em grau de apelação, a sentença de mérito, ou que tenham julgado procedente ação rescisória. Pontes de Miranda (1932 apud JACOBY FERNANDES, 2008, p. 172) há tempos já havia examinado essa questão, restando assentado que não cabe 
ao juiz comum conhecer de qualquer infringência ou de qualquer modificação no julgado do Tribunal de Contas. Caso houvesse previsão para a interposição de embargos infringentes, estes seriam julgados pela própria Corte de Contas. ${ }^{89}$

Para Zymler (2009), diante da existência concomitante de ação de execução de acórdão do TCU e de ação ordinária de cobrança - ambas fundadas em fatos jurídicos similares -, observa-se muitas vezes que a AGU ou as procuradorias das entidades da administração indireta adotam como padrão de comportamento a continuidade ou mesmo o ajuizamento de ações de conhecimento em detrimento da execução das decisões da Corte de Contas.

Para o autor, o órgão responsável não pode se eximir do ajuizamento da ação de execução de acórdão condenatório do TCU sob a alegação da existência prévia de ação de cobrança ordinária, mesmo que se considere a possibilidade da interposição, pelo devedor, de embargos à execução, face à existência de ação de conhecimento em curso. Zymler (2009) constata que, geralmente, a obtenção de um título judicial hábil a ser executado, a partir de uma ação de conhecimento, e sua posterior liquidação, é um processo demorado. Assim, mesmo que o ajuizamento da ação ordinária de cobrança seja feita antes da publicação do acórdão condenatório do TCU, o meio mais eficaz para a recuperação do crédito será a cobrança executiva deste título.

Tendo em vista a possibilidade de haver ações judiciais concomitantes ao processo de contas, o art. $9^{\circ}$ da IN TCU n ${ }^{\circ} 56$, de 2007, prevê que, ao julgar tomada de contas especial cuja matéria se encontre sob apreciação do Poder Judiciário, o TCU pode comunicar a decisão à autoridade judicial competente.

Conquanto louvável o escopo do aludido dispositivo, no sentido de munir o juiz de elemento indispensável a sua sentença, em verdade tal juiz deveria declarar sua incompetência absoluta para apreciar a matéria, remetendo-se os autos ao juízo competente, nos termos do art. $113, \S 2^{\circ}$, do CPC. O juízo competente não é outro senão o Tribunal de Contas competente para julgar as contas do responsável. Ressalva-se, contudo, a possibilidade de o Judiciário admitir ações contra decisões dos Tribunais de Contas após a decisão definitiva destes, ainda assim para tão-somente verificar a observância de aspectos extrínsecos atinentes à observância do devido processo legal, sem adentrar o mérito dos julgamentos.

89 Já houve a previsão do recurso de embargos infringentes no âmbito do TCU pela revogada Lei $\mathrm{n}^{\circ} 830$, de 1949. 
Uma solução alternativa razoável, já mencionada neste item, para ações judiciais que busquem inibir os efeitos de processo ainda em tramitação no Tribunal de Contas, vislumbrada por Jacoby Fernandes (1996), está contida no art. 265, IV, “a”, do CPC, que determina a suspensão do processo quando a sentença de mérito "depender do julgamento de outra causa, ou da declaração da existência ou inexistência da relação jurídica, que constitua o objeto principal de outro processo pendente".

Outra questão assaz relevante diz respeito à prescrição para a constituição do título executivo consubstanciado na decisão condenatória. O STF, no julgamento do MS 26210/DF, de relatoria do Ministro Ricardo Lewandowski, deixou assente o entendimento de que inexiste prazo prescricional para ações que visem ao ressarcimento de danos causados ao Erário, em face do disposto no $\S 5^{\circ}$ do art. 37 da Constituição Federal. Segundo Chaves (2009), uma vez constituído título executivo que comine multa, aplica-se à pretensão de executá-la judicialmente o prazo prescricional de cinco anos (art. 206, § 5º I, do Código Civil). Contudo, uma vez constituído título executivo que impute débito, há a imprescritibilidade da pretensão para executá-lo, ou seja, o débito imputado em um acórdão condenatório pode ser cobrado a qualquer tempo.

\subsection{Alternativas à sistemática de execução em vigor}

De acordo com a sistemática vigente, a capacidade postulatória ativa para a execução judicial das decisões condenatórias não compete aos Tribunais de Contas que as proferiram, mas sim aos órgãos competentes para a representação judicial do ente federado ou da entidade da Administração Indireta.

Nos termos do art. 131 da $\mathrm{CF}$, compete à AGU representar a União judicial e extrajudicialmente e, de acordo com o art. 132 do texto constitucional, a representação judicial dos Estados e do Distrito Federal compete aos respectivos Procuradores, organizados em carreira.

Assim, nada obstante o fato de a condenação em débito incumbir ao Tribunal de Contas, no exercício da competência judicante prevista no inciso II do art. 71 da CF, a definição da titularidade para promover a cobrança judicial de débito imputado depende do ente federativo cujos cofres tenham sido lesados. No caso de decisões condenatórias proferidas pelo TCU, se o cofre lesado foi o da União, o ajuizamento incumbe ao órgão responsável por sua representação judicial, ou seja, à AGU, à qual também cabe ingressar em juízo no caso de recursos públicos pertencentes a autarquias e a fundações federais por ela 
atendidas. Já quando o patrimônio lesado for de entidade federal pertencente à Administração Indireta, desde que tal entidade tenha departamento jurídico próprio, compete a este promover a ação de execução do acórdão condenatório (CHAVES, 2009). ${ }^{90}$

No caso de decisões condenatórias em débito proferidas pelos TCEs e TCMs, se o cofre lesado for de ente estadual, cabe aos Procuradores do Estado o ajuizamento da ação de execução, mas, se o cofre lesado for de ente municipal, a capacidade postulatória ativa pertence aos Procuradores do Município, onde houver (CHAVES, 2009). Se o cofre lesado for de entidade da Administração Indireta estadual ou municipal, incumbe ao respectivo departamento jurídico o ajuizamento. Já no caso de Municípios que não tenham procuradores em seu quadro funcional - que correspondem à maioria dos mais de cinco mil municípios brasileiros - a representação judicial competirá a escritórios de advocacia privados contratados pelo Poder Público (CALDAS, 2011). ${ }^{91}$

Mas as regras acima aplicam-se apenas à imputação de débitos. No caso da cominação de multas pelos Tribunais de Contas, no exercício da competência prevista no inciso VIII do art. 71 da Carta Constitucional, seu pagamento reverterá diretamente aos cofres do ente federado, razão pela qual sua execução compete, para multas aplicadas pelo TCU, à AGU e, para multas aplicadas pelos TCEs e TCMs, aos Procuradores do Estado. ${ }^{92}$

No âmbito do TCU, a Resolução-TCU nº 178, de 24 de agosto de 2005, estabelece procedimentos para a autuação de processos de cobrança executiva e para a organização da documentação a ser remetida aos órgãos ou entidades executoras. Em apertada síntese,

90 À Procuradoria-Geral da União (PGU), órgão de direção superior da AGU, compete representar a União judicialmente, incumbindo-lhe a execução de títulos extrajudiciais expedidos pelo TCU quando os créditos contidos nos acórdãos condenatórios pertencerem à União (art. $2^{\circ}$ da Lei Complementar $\mathrm{n}^{\circ} 75 / 93 \mathrm{c} / \mathrm{c} o$ art. $8^{\circ}$ $\mathrm{E}$ da Lei $\mathrm{n}^{\circ}$ 9.028/95). Isto ocorre quando as decisões condenatórias são prolatadas em processos de contas envolvendo órgãos da administração direta. Tais decisões não são inscritas em dívida ativa, pois a inscrição implicaria o deslocamento da competência executória para a Procuradoria-Geral da Fazenda Nacional (PGFN), por força do disposto no art. 23 da Lei n 11.457 , de 16 de março de 2007.

Por outro lado, à Procuradoria-Geral Federal (PGF) compete a representação judicial das autarquias e fundações públicas federais, incumbindo-lhe a apuração da certeza e da liquidez de seus respectivos créditos, de qualquer natureza, inscrevendo-os em dívida ativa para fins de cobrança amigável ou judicial (art. 10 da Lei $\mathrm{n}^{\mathrm{o}}$ 10.480/2002). Portanto, acórdãos condenatórios proferidos em processos de contas envolvendo entidades da administração indireta autárquica e fundacional são inscritos em dívida ativa e executados judicialmente pela PGF.

Para mais detalhes, recomenda-se consultar o parecer de lavra do Procurador do MP/TCU Marinus Eduardo de Vries Marsico, cujo inteiro teor encontra-se reproduzido no Relatório do Acórdão n 1.603/2011 - TCU Plenário, relatado pelo Ministro Ubiratan Aguiar.

91 Excepcionalmente, diante da inércia das procuradorias locais, a jurisprudência tem admitido a execução das decisões condenatórias proferidas por TCEs pelo próprio Ministério Público Estadual. Para mais detalhes, sugere-se a consulta a trecho de parecer da Consultoria Jurídica do TCU, transcrito no Relatório do Acórdão $n^{\circ} 1.603 / 2011$ - TCU - Plenário, relatado pelo Ministro Ubiratan Aguiar.

92 Exceção feita às multas aplicadas pelo TCM-RJ e pelo TCM-SP (órgãos municipais), cujos valores são revertidos aos cofres municipais, incumbindo o ajuizamento da execução à Procuradoria do respectivo Município. 
prolatado o acórdão condenatório, a Secretaria das Sessões encaminha-o à unidade técnica que atuou na fase instrutória do processo. Tal unidade deve organizar a documentação necessária à propositura da ação de execução pelos órgãos competentes e autuar o respectivo processo administrativo de cobrança executiva. Tal processo é conferido e encaminhado ao MP/TCU, responsável por promover, perante o órgão ou entidade competente, a cobrança judicial da dívida. Alfim, o processo executivo é devolvido à unidade técnica e apensado aos autos que geraram a condenação. ${ }^{93}$

Já no âmbito do TCE-RS, Miola (2011) dá notícia da instituição do Projeto ACD (Acompanhamento do Cumprimento de Decisões) pelo Ministério Público de Contas que atua junto àquela Corte (MP/TCE-RS), definindo um conjunto de atividades com vistas a zelar pelo cumprimento das decisões emanadas do Tribunal de Contas gaúcho.

Em linhas gerais, o referido projeto envolve o acompanhamento, pelo MP/TCE$\mathrm{RS}$, das providências administrativas ou judiciais adotadas pelas autoridades competentes para a propositura das ações de execução judicial. Diante da omissão, inércia ou ineficácia do agente responsável pelo ajuizamento da ação de execução, o MP/TCE-RS: a) encaminha representação ao TCE-RS para examinar os fatos em seus procedimentos de auditoria e considerar a conduta do administrador, tido por inerte, como agravante na análise de suas contas; b) encaminha a matéria ao Ministério Público Estadual, para apuração de eventual ocorrência de ato de improbidade administrativa ou de ilícito penal. ${ }^{94}$

No item anterior, apontaram-se algumas alternativas a partir de cuja adoção vislumbra-se uma possibilidade de aumento de efetividade na recuperação judicial dos valores condenatórios, todas contidas nos estritos limites da sistemática vigente de ajuizamento pelos órgãos executores.

Sem prejuízo disto, faz-se oportuno abordar, neste momento, alternativas à própria sistemática vigente. Está-se a tratar, basicamente, de duas polêmicas questões: a atribuição de capacidade postulatória ativa aos Tribunais de Contas para executar judicialmente suas próprias decisões; e a autoexecutoriedade das decisões condenatórias.

93 O Acórdão n ${ }^{\text {o }}$ 1.964/2004 -TCU - Plenário (Sessão Reservada) alterou sensivelmente a rotina de trabalho relacionada aos processos de cobrança executiva. Por meio de tal Acórdão, o Tribunal decidiu firmar o entendimento de que, após a remessa aos órgãos executores competentes da documentação necessária ao ajuizamento dos processos de cobrança executiva, não mais haverá a intervenção do TCU no processo no que se refere a quesitos que interfiram nas providências a cargo desses órgãos, especialmente no tocante ao recebimento extrajudicial dos valores constantes dos acórdãos condenatórios (ZYMLER, 2009).

94 Segundo Miola (2011), o Projeto ACD tem propiciado inclusive uma proveitosa interação entre o MP/TCERS e o Ministério Público Estadual. 


\subsubsection{Capacidade postulatória ativa dos Tribunais de Contas}

O Ministro Ubiratan Aguiar (informação verbal) ${ }^{95}$, na condição de Presidente do TCU no biênio 2009/2010, afirmou que havia conjecturado sobre a criação de uma unidade no Tribunal exclusivamente para "mover ações de execução de acórdãos que condenam gestores públicos e empresas pelo desvio de verbas da União", mas sua idéia inicial foi superada a partir do diálogo e do estabelecimento de parceria com a $\mathrm{AGU}^{96,97}$.

Desde 2007, encontra-se instalado no TCU um escritório avançado da AGU, cujo quadro funcional subiu, em 2010, de quatro para vinte profissionais (AGU, 2011). Além disso, o próprio TCU aprimorou seus procedimentos internos após a prolação dos acordos condenatórios, agilizando sobremaneira o encaminhamento dos processos administrativos de cobrança executiva ao MP/TCU, com vistas a promover a cobrança judicial dos títulos. Nesse sentido, em janeiro de 2009, $17 \%$ dos processos de cobrança executiva eram encaminhados ao MP/TCU fora dos prazos regulamentares e, em dezembro de 2010, apenas $1 \%$ desses processos foram encaminhados intempestivamente (TCU, 2010c). ${ }^{98}$

De toda sorte, a aludida conjectura inicial do Ministro Ubiratan Aguiar (informação verbal) $^{99}$ possivelmente encontraria óbices de natureza jurídica, de vez que a possibilidade de o Tribunal de Contas executar diretamente - ou por intermédio do Ministério Público que junto a ele atue - suas decisões perante o Poder Judiciário, sem a intermediação dos órgãos executores, a exemplo da AGU e das Procuradorias Estaduais, já foi objeto de manifestação contrária do STF.

Ao apreciar recurso extraordinário interposto pelo TCE-SE tendo por objeto dispositivo da Constituição do Estado de Sergipe que permitia à Corte de Contas sergipana

95 Palestra proferida por ocasião do III Congresso da Advocacia Pública, realizado em Brasília de 8 a 11 de setembro de 2009 (Caldas, 2011, p. 326).

96 Encontra-se em vigor Acordo de Cooperação Técnica firmado entre a AGU e o TCU em 09/04/2008, tendo "por finalidade facilitar e agilizar o fornecimento de documentos e informações, visando a [...] conferir maior celeridade aos procedimentos ou processos que envolvam a cobrança de débitos e multas referentes às decisões do TCU”.

97 Importante registrar a instituição da Rede de Controle da Gestão Pública, a partir do Protocolo de Intenções firmado em 25 de março de 2009, congregando vários órgãos e entidades visando à fiscalização e ao controle articulados da gestão pública. Um produto da Rede de Controle é o Cadastro Integrado de Condenações por Atos Ilícitos (Cadicon), que já é alimentado por vários Tribunais de Contas, para a identificação de gestores que tiveram suas contas julgadas irregulares pelo TCU, TCDF, TCEs e TCMs.

98 Tal redução na intempestividade do encaminhamento de processos de cobrança executiva deve-se, em boa parte, ao disposto no item 9.2.1 do Acórdão no 995/2008 - Plenário, segundo o qual o descumprimento dos prazos fixados na Resolução-TCU no 178/2005, para autuação e encaminhamento dos processos de cobrança executiva, passou a ser caracterizado como desídia, nos termos do art. 117, XV, da Lei no 8.112, de 1990, sujeitando o infrator às sanções disciplinares cabíveis (TCU, 2008).

99 Palestra proferida por ocasião do III Congresso da Advocacia Pública, realizado em Brasília de 8 a 11 de setembro de 2009 (Caldas, 2011, p. 326). 
executar judicialmente suas próprias decisões ${ }^{100}$, o STF entendeu que o Tribunal de Contas carece de titularidade, legitimidade e interesse imediato e concreto na ação executória, razão pela qual manifestou-se pela inconstitucionalidade incidental do referido permissivo, por violação ao princípio da simetria, contido no art. 75 da CF. Eis a ementa do julgado:

EMENTA: RECURSO EXTRAORDINÁRIO. TRIBUNAL DE CONTAS DO ESTADO DE SERGIPE. COMPETÊNCIA PARA EXECUTAR SUAS PRÓPRIAS DECISÕES: IMPOSSIBILIDADE. NORMA PERMISSIVA CONTIDA NA CARTA ESTADUAL. INCONSTITUCIONALIDADE.

1. As decisões das Cortes de Contas que impõem condenação patrimonial aos responsáveis por irregularidades no uso de bens públicos têm eficácia de título executivo $\left(\mathrm{CF}\right.$, artigo $\left.71, \S 3^{\circ}\right)$. Não podem, contudo, ser executadas por iniciativa do próprio Tribunal de Contas, seja diretamente ou por meio do Ministério Público que atua perante ele. Ausência de titularidade, legitimidade e interesse imediato e concreto. 2. A ação de cobrança somente pode ser proposta pelo ente público beneficiário da condenação imposta pelo Tribunal de Contas, por intermédio de seus procuradores que atuam junto ao órgão jurisdicional competente. 3. Norma inserida na Constituição do Estado de Sergipe, que permite ao Tribunal de Contas local executar suas próprias decisões (CE, artigo 68, XI). Competência não contemplada no modelo federal. Declaração de inconstitucionalidade, incidenter tantum, por violação ao princípio da simetria $(\mathrm{CF}$, artigo 75$)$. Recurso extraordinário não conhecido. (STF, Tribunal Pleno, RE 223037/SE. Relator: Min. Maurício Corrêa. Julgamento em 02/05/2002. Publicado no DJ de 02/08/2002, grifos nossos).

O entendimento do STF significaria, a princípio, um ponto final na polêmica questão da capacidade postulatória ativa dos Tribunais de Contas, não fosse a problemática da independência altamente contestável dos órgãos executores estaduais e, principalmente, municipais diante das pessoas responsabilizadas nos acórdãos condenatórios ${ }^{101,102}$.

100 A Constituição do Estado do Rio de Janeiro prevê, em seu art. 133, parágrafo único, que a representação judicial do TCE-RJ se dará por meio dos Procuradores integrantes de sua Procuradoria-Geral, nos termos de lei complementar. A Lei Complementar $n^{\circ}$ 94, de 2000, do Estado do Rio de Janeiro prevê, em seu art. $5^{\circ}$, que a organização e o funcionamento da Procuradoria-Geral do TCE-RJ dar-se-á nos termos de resolução específica deste Tribunal. Nesse sentido, a Resolução TCE-RJ $\mathrm{n}^{\circ}$ 227, de 2000, prevê que compete à Procuradoria-Geral do Tribunal de Contas "cobrar judicialmente os débitos e multas, apurados ou aplicados em decisão definitiva do Tribunal de Contas, e não saldadas no tempo devido" (FERRAZ, 2003, p. 221-222). Mais recentemente, a Resolução TCE-RJ n ${ }^{\circ} 262$, de 8 de abril de 2010, prevê que as atribuições de representação judicial do TCE-RJ são exercidas pelos Procuradores da Corte fluminense exclusivamente em favor do órgão.

101 Entende-se que, no âmbito federal, o problema seja menos grave, já que a AGU tem demonstrado atuação com independência e autonomia na execução dos julgados do TCU, o que não afasta completamente, pelo menos do ponto de vista teórico, o problema de sua submissão à Presidência da República, haja vista o exercício de atividades de consultoria e assessoramento jurídico do Poder Executivo, nos termos do art. 131 da Constituição Federal.

102 Encontra-se em tramitação, no Senado Federal, a PEC n 25/2009, que pretende atribuir capacidade postulatória ativa aos Tribunais de Contas para o ajuizamento da execução de suas decisões. 
Nesse contexto, importante registrar a posição de Ferraz (2003), que defende o reconhecimento de capacidade postulatória ativa aos Tribunais de Contas ${ }^{103}$. Segundo o autor, inexiste previsão, no ordenamento jurídico brasileiro, que explicite a quem compete a cobrança judicial dos valores condenatórios, em que pese a previsão da representação judicial da União e dos Estados, respectivamente, pela AGU e pelas respectivas Procuradorias.

Ferraz (2003, p. 219-220) prossegue afirmando que, ao contrário do que se dá com os Tribunais de Contas e com o Ministério Público, que são instituições estatais independentes, os órgãos de representação judicial dos entes federados são instituições constitucionais subordinadas ao Poder Executivo. Transcreve-se a seguir excerto de sua autoria:

Como atribuir então - e é isso que se tem feito! - a uma instituição subordinada a um dos Poderes de Estado a execução da decisão proveniente de uma instituição independente? E, pior ainda, como fazer quando, por exemplo, o agente multado ou executado for o próprio Chefe do Executivo, de seu turno também Chefe da Advocacia Pública? A par disso, figure-se que os títulos executivos, resultantes das decisões dos Tribunais de Contas, são apenas um, dentre os vários mananciais de outros títulos executivos, originários de outros segmentos estatais, a confluírem para a atuação judicial de cobrança das Advocacias Públicas. O que acontece hoje: os débitos impostos pelos Tribunais de Contas são relegados para segundo plano, quando não mesmo são desconsiderados por inspirações subalternas (v.g., quando o alvo da cobrança é um alto dirigente do Poder Executivo, ou mesmo, da instituição da advocacia pública!).

Miola (2011) assim se manifesta sobre a questão da independência dos órgãos executores (grifo nosso):

Essa ineficiência, que atenta contra os demais princípios constitucionais que se postam na regência da atividade de administração pública, não somente se atribui ao fato de não se bastarem as Cortes de Contas, mas também, em consequência, e por infelicidade, à evidência de que, muitas vezes, os atingidos pelas decisões são os próprios titulares do processo executivo, são correligionários destes ou com os mesmos detêm outros vínculos.

Conquanto a suprarreferida abordagem de Ferraz (2003) se revele extremamente oportuna no que diz respeito à questionável independência dos órgãos executores - mormente em Municípios pequenos, com recursos escassos e que precisam contratar escritórios de

${ }^{103}$ Alvares (1996) considera importante a criação de mecanismos legais para dar efetividade às decisões do TCU e entende como válida a alternativa de conferir poderes para que o Tribunal execute perante a Justiça suas próprias decisões. 
advocacia privados para a execução judicial das decisões proferidas pelos TCEs $^{104}$-, algumas questões restam pendentes na alternativa proposta pelo autor: qual seria a solução para o fato de os Tribunais de Contas pertencerem à Administração Direta e não deterem personalidade jurídica própria para atuar em juízo? Se os Tribunais de Contas são órgãos pertencentes a entes federados cuja representação judicial foi atribuída constitucionalmente à AGU ou às Procuradorias locais, como poderiam eles pleitear em juízo direitos pertencentes a tais entes?

Foge ao escopo deste trabalho responder a tais questões. Fato é que, para uma eventual atribuição de capacidade postulatória ativa aos Tribunais de Contas para executar judicialmente suas próprias decisões, far-se-iam necessários estudos adicionais visando a uma reestruturação na forma de atuação de tais órgãos.

\subsubsection{Autoexecutoriedade das decisões condenatórias}

Outra polêmica alternativa que se põe é a autoexecutoriedade das decisões condenatórias, ou seja, a atribuição de competência para que os acórdãos imputadores de débito ou cominadores de multa fossem executados coercitivamente contra o devedor pelos próprios Tribunais de Contas que proferiram as decisões. Em tal perspectiva, as Cortes de Contas atuariam como se ao Judiciário pertencessem. ${ }^{105}$

Martins (1998 apud YAMADA, 2005, p. 84-85) ${ }^{106}$ assim se manifesta sobre a transformação do Tribunal de Contas em órgão judicial (grifos nossos):

Há anos venho defendendo a tese de que o Tribunal de Contas deveria compor o Poder Judiciário e não o Poder Legislativo, passando, portanto, a ser um autêntico Poder Responsabilizador. Em meu livro Roteiro para uma Constituição, defendi a idéia de que o Poder Judiciário deveria possuir três vertentes. Uma de administração da Justiça, com duplo grau de jurisdição. Outra de preservação da Constituição, atribuindo-se tal poder a uma Corte Constitucional. E uma terceira de responsabilização da Administração Pública, a ser exercida pelo Tribunal de Contas, cujos cargos haveriam de ter provimento inicial nos moldes dos de carreira judiciária.

$[\ldots]$

Ganharia o Tribunal de Contas em dignidade e eficácia, e todos os poderes ficariam mais alertas e cautelosos na administração da coisa pública e no

${ }^{104}$ Ressalvam-se os Municípios pertencentes aos Estados da Bahia, Ceará, Goiás e Pará, que possuem TCMs (TCM-BA; TCM-CE; TCM-GO; TCM-PA), em cujas competências se insere o julgamento das contas dos responsáveis por recursos públicos municipais.

105 Conforme mencionado alhures, a ausência de autoexecutoriedade não pode ser alegada para afastar o exercício da atividade jurisdiccional pelos Tribunais de Contas, já que raramente um Tribunal é o executor direto de sua própria decisão, a qual, em geral, é executada pelo primeiro grau de jurisdição (JACOBY FERNANDES, 2008).

106 Para um maior aprofundamento, pode-se consultar a obra "Comentários à Constituição do Brasil: promulgada em 5 de outubro de 1988”, p. 14-18, de autoria do Professor Ives Gandra da Silva Martins. 
controle dos dinheiros do Estado, que, em verdade, pertencem à sociedade e não aos detentores do poder.

A idéia não prosperou na Constituinte de 1988. O Congresso Nacional não quis perder poder.

A ousada ideia defendida pelo eminente jurista, conquanto possa parecer um tanto quanto distante da configuração institucional do Estado Brasileiro no que se refere à autoexecutoriedade, coaduna-se, de certa forma, com competência específica prevista na legislação infraconstitucional. Está-se a tratar da previsão contida no inciso I, do art. 28, da Lei n ${ }^{\circ} 8.443$, de 1992, c/c o art. 219, I, do RITCU, segundo a qual poderá o TCU “determinar o desconto integral ou parcelado da dívida nos vencimentos, salários ou proventos do responsável, observados os limites previstos na legislação pertinente" após o decurso do prazo de quinze dias contados da publicação da notificação para o pagamento da quantia correspondente ao débito ou à multa.

Reconhece-se que a referida competência representa apenas uma limitada possibilidade de o TCU executar suas próprias decisões condenatórias, a qual - não logrando êxito - ensejará a cobrança judicial da dívida, conforme previsto no art. 219, II, do RITCU, mas não há dúvidas de que resta aí caracterizada uma forma, ainda que singela, de autoexecutoriedade.

Em entrevista, Aguiar (informação verbal) ${ }^{107}$, ao final de sua gestão como Presidente do TCU no biênio 2009/2010, ao ser questionado sobre como enxergava o órgão no futuro, manifestou preocupação com relação ao fato de que, apesar de o TCU proferir decisões condenatórias, não possui competência para executar suas próprias decisões, muito embora a AGU - na qualidade de órgão executor - estivesse desempenhando um trabalho a contento. Eis as palavras do eminente Ministro Ubiratan Aguiar na referida entrevista:

Hoje, a legislação estabelece que nós podemos condenar, aplicar multa e dar nota de improbidade administrativa, mas nós não executamos os recursos das multas e dos débitos que são desviados. É preciso permitir que o TCU tenha a auto-executoriedade, ainda que a AGU esteja realizando um trabalho eficiente. Há necessidade, e isso eu tenho discutido muito, de sermos mais efetivos na tomada dessas providências, pois, em alguns casos, os gestores condenados começam a se desfazer do patrimônio. Quando você vai executar, não tem como recuperar o que foi desviado, os bens foram passados para terceiros.

107 Entrevista concedida ao jornal Diário do Nordeste (Fortaleza-CE) de 13/12/2010. 
Certamente, a autoexecutoriedade das decisões condenatórias não é possível com a configuração institucional atual do Estado Brasileiro. Para que os Tribunais de Contas executassem suas próprias decisões, precisariam transformar-se em órgãos do Poder Judiciário, a exemplo do que ocorre em Portugal.

Ferraz (2003) menciona que, na Constituição Portuguesa (art. 209º), o Tribunal de Contas foi inserido no Poder Judiciário e a Lei Orgânica de tal Corte atribui, logo em seu art. $1^{\circ}$, natureza jurisdicional às decisões da Corte. $\mathrm{O}$ autor prossegue afirmando o seguinte:

No que diz respeito à execução das decisões, a Lei no 98/97, em seu art. $8^{\circ}$, a defere aos "Tribunais Tributários de primeira instância", com aplicação do "processo de execução fiscal". Inexiste, na Lei, comando expresso explicitador de a quem cabe a provocação da execução. E embora pareça ela encartada na competência geral do Ministério Público, cremos que poderia ser útil, em razão dos princípios constitucionais bem anteriormente referidos, também prestigiados na ordem constitucional portuguesa, o exame, pelos juristas lusitanos, da estruturação de seu sistema autônomo de execução das decisões dos Tribunais de Contas, de sorte a lhes garantir o máximo de efetividade.

A partir do excerto acima, colocam-se algumas questões a título de reflexão, cujas respostas escapam aos objetivos deste trabalho. Se os Tribunais de Contas brasileiros fossem inseridos, mediante reforma constitucional, no âmbito do Poder Judiciário, tais órgãos não poderiam, a princípio, agir de ofício, por força do princípio da inércia judicial. A que órgão caberia provocá-los para que conhecessem as questões e executassem suas próprias decisões? Criar-se-iam Auditorias-Gerais no âmbito dos Poderes Executivo e Legislativo para provocálos e municiá-los das informações necessárias ao processo de execução?

Obviamente, o princípio da inércia judicial não é absoluto ${ }^{108}$, mas tal questão representaria um obstáculo a ser superado para a autoexecutoriedade das decisões em processos de julgamento de contas. Ademais, seria necessário um rearranjo na própria posição institucional ocupada por tais órgãos no Estado Brasileiro.

\footnotetext{
${ }^{108}$ Assim, por exemplo, a execução trabalhista pode ser promovida ex officio pela Justiça do Trabalho.
} 


\section{CONSIDERAÇÕES FINAIS}

Conforme restou demonstrado no decorrer do presente trabalho, as competências atribuídas constitucionalmente aos Tribunais de Contas de “julgar as contas dos administradores e demais responsáveis por dinheiros, bens e valores públicos [...] e as contas daqueles que derem causa a perda, extravio ou outra irregularidade de que resulte prejuízo ao erário público" (art. 71, II, da CF) e de "aplicar aos responsáveis, em caso de ilegalidade de despesa ou irregularidade de contas [...] multa proporcional ao dano causado ao erário" (art. 71, VIII, da CF) correspondem a funções de caráter jurisdicional outorgadas constitucionalmente às Cortes de Contas, que podem resultar na prolação de acórdãos condenatórios com eficácia de título executivo, nos termos do art. $71, \S 3^{\circ}$, da $\mathrm{CF}$.

Tais decisões condenatórias são proferidas em processos administrativos de contas, em cujo bojo são amplamente assegurados aos responsáveis o contraditório e a ampla defesa, inclusive mediante a interposição de recursos, muitos dos quais com efeito suspensivo. Os processos de contas são informados pelos princípios da verdade material e do formalismo moderado, tendo em vista os interesses de caráter eminentemente público em discussão. Em que pese tais decisões serem prolatadas em processos administrativos, os julgamentos de contas proferidos por estes órgãos representam autêntico exercício da jurisdição estatal, pois a mesma Constituição que estabeleceu o princípio da unicidade da jurisdição em favor do Poder Judiciário também pode excepcioná-lo em certas hipóteses, de que é exemplo o exercício da jurisdição constitucional de contas.

De forma consentânea com a competência judicante atribuída às Cortes de Contas pela CF, e considerando o princípio da inafastabilidade do Poder Judiciário, a este cabe apreciar as decisões proferidas em processos de contas, mas tão-somente no que se refere a seus aspectos extrínsecos, verificando a presença de ilegalidade manifesta ou de irregularidades de caráter formal. Tal é o entendimento do STF, segundo o qual os julgamentos de contas revestem-se de caráter definitivo, não competindo ao Poder Judiciário adentrar o mérito das decisões para modificá-las. Tal revisibilidade, portanto, deve-se ater à verificação do respeito ao devido processo legal, o qual - se não observado - deve levar à restituição do caso à Corte de Contas competente, para novo julgamento.

Caso não haja o recolhimento do valor condenatório pelo responsável ao qual haja sido imputado débito ou cominada multa, e se não for possível ao Tribunal determinar o 
desconto integral ou parcelado da dívida na remuneração do responsável que seja agente público, as decisões condenatórias devem ser executadas judicialmente. Para este fim, quis o legislador dotar tais decisões da eficácia de título executivo, não especificando, contudo, se este possui natureza judicial ou extrajudicial.

Em que pese haver alguns autores que defendem, de um lado, reformas no ordenamento jurídico para atribuir às decisões condenatórias eficácia de título executivo judicial e, de outro, doutrinadores que reconhecem a tais títulos a mesma eficácia de um título executivo extrajudicial comum, o melhor entendimento é aquele segundo o qual os acórdãos condenatórios prolatados em processos de contas consubstanciam-se em títulos executivos extrajudiciais - em virtude de os Tribunais de Contas não pertencerem aos Poder Judiciário -, contudo dotados de força executiva bem maior que aquela atribuída aos títulos extrajudiciais em geral.

Nesse sentido, não se pode conferir às decisões condenatórias a mesma eficácia atribuída a quaisquer dos títulos executivos extrajudiciais arrolados no art. 585 do CPC. Em face destes, o devedor pode alegar, em sede de embargos à execução, qualquer matéria que lhe seria lícito deduzir como defesa no processo de conhecimento, conforme prevê o inciso $\mathrm{V}$ do art. 745 do CPC. Tal dispositivo não é aplicável à execução dos acórdãos condenatórios, pois o Poder Judiciário carece de competência para examinar o mérito dos julgamentos de contas, razão pela qual o melhor entendimento é aquele segundo o qual ao devedor é permitido alegar em face de tais títulos, por meio de embargos à execução, apenas matérias atinentes a ilegalidade manifesta ou a irregularidades de ordem formal. Impende destacar, quanto a este ponto, que o contraditório e a ampla defesa já restaram suficientemente assegurados ao executado no próprio processo administrativo de julgamento de contas, no qual já houve a cognição da matéria.

Considerando que o débito imputado ou a multa cominada caracterizam-se como dívida ativa não tributária, nos termos da Lei $n^{\circ} 4.320$, de 1964, as respectivas ações de cobrança judicial devem seguir o rito previsto na Lei ${ }^{\circ} 6.830$, de 1980 , referente à execução fiscal, não sendo necessário, contudo, a inscrição em dívida ativa, pois as decisões condenatórias já se revestem dos atributos de certeza e liquidez, tendo sido a estas conferida constitucionalmente a eficácia de título executivo.

O ajuizamento da ação de execução não incumbe, todavia, às Cortes de Contas que prolataram as decisões condenatórias, mas sim aos órgãos competentes para representar judicialmente o ente federado ou a entidade da Administração Indireta que tenha interesse na 
ação de execução. Assim, na esfera federal, a capacidade postulatória ativa compete à AGU para débitos correspondentes a desfalques sofridos pelos cofres do ente federado ou para multas em geral - ou a procuradorias específicas, no caso da imputação de débitos relativos a danos sofridos pelas entidades integrantes da administração indireta que tenham unidade de representação judicial em sua estrutura.

A partir da sistemática vigente de ajuizamento das ações de execução por órgãos ou entidades outros que não os próprios Tribunais de Contas, e considerando a elevada monta que atingem os valores condenatórios, bem como os dados divergentes a respeito da efetividade em sua recuperação judicial, abordaram-se aspectos que vão desde as prestações de contas e a autuação de tomadas de contas especiais, passando pela tramitação dos processos de contas e a prolação das decisões definitivas, até a abordagem de instrumentos previstos na legislação processual civil e a própria defesa da jurisdição constitucional de contas perante o Poder Judiciário, tudo com vistas a otimizar os procedimentos envolvidos na recuperação judicial dos valores, com potencial ganho de efetividade e uma cessação da sensação de impunidade na malversação de recursos públicos.

Por fim, questionou-se a própria sistemática vigente de execução das decisões condenatórias por órgãos de representação judicial perante o Poder Judiciário, abordando-se as polêmicas questões da atribuição de capacidade postulatória ativa aos Tribunais de Contas para executar judicialmente suas próprias decisões e a viabilidade da autoexecutoriedade de tais decisões.

No que tange à outorga de capacidade postulatória ativa aos Tribunais de Contas, mencionou-se a problemática da questionável independência dos agentes incumbidos da execução diante dos responsáveis julgados em alcance ou multados, principalmente - mas não só - em Municípios pequenos, nos quais a execução pode depender, por exemplo, da contratação de escritórios de advocacia pelas respectivas Prefeituras. Nada obstante isto, haveria a necessidade de alteração na forma de atuação das Cortes de Contas e nas próprias competências atribuídas à AGU e às Procuradorias Estaduais, a quem compete atualmente defender em juízo os interesses dos respectivos entes federados.

No tocante à autoexecutoriedade das decisões, para que os próprios Tribunais de Contas agissem coercitivamente contra o patrimônio dos executados, mister se faria que tais Cortes atuassem na qualidade de órgãos judiciais, mas ainda assim seria necessária a presença de um agente provocador para que os Tribunais de Contas passassem à etapa de execução de suas decisões, uma vez esgotada a fase cognitiva sem que houvesse o cumprimento da 
obrigação constante do título condenatório. Isso implicaria a necessidade de se repensar a posição institucional ocupada por tais órgãos no Estado Brasileiro.

Destarte, no momento em que se cogitam alternativas futuras para aprimorar ainda mais os relevantes resultados advindos do exercício das competências constitucionalmente atribuídas às Cortes de Contas, não se pode perder de vista a visão originária externada pelo defensor maior da criação da instituição Tribunal de Contas, o Ministro da Fazenda Rui Barbosa, no sentido de que o Tribunal, "colocado em posição autônoma, com atribuições de revisão e julgamento, cercado de garantias contra quaisquer ameaças, possa exercer as suas funções vitais no organismo constitucional" ${ }^{, 109}$.

${ }^{109}$ Palavras de Rui Barbosa, Ministro da Fazenda, na Exposição de Motivos ao Decreto nº 966-A, de 7 de novembro de 1890, que criou o Tribunal de Contas da União. 


\section{REFERÊNCIAS}

ADVOCACIA-GERAL DA UNIÃO. Grupo Permanente Atuação Pró-ativa. Departamento de Patrimônio Público e Probidade Administrativa. Relatório das Ações Ajuizadas. Período: dezembro de 2009 a novembro de 2010. Brasília, 2010. 12 p.

Acordo de cooperação que entre si celebram a Advocacia-Geral da União e o Tribunal de Contas da União. Objeto: Facilitar e agilizar o fornecimento de documentos e informações, visando ao adequado cumprimento das determinações do TCU no âmbito da Administração Pública Federal, bem como a conferir maior celeridade aos procedimentos ou processos que envolvam a cobrança de débitos e multas referentes às decisões do TCU. Diário Oficial da União de 23 abr. 2008. Brasília, 2008.

Escritórios avançados consolidam prerrogativa da AGU de representar os Três Poderes. Disponível em:

$<$ http://www.agu.gov.br/sistemas/site/TemplateImagemTexto.aspx?idConteudo=123885\&id_ site $=3>$. Acesso em: 08 out. 2011.

AFFONSO, Sebastião Baptista. Eficácia das decisões dos tribunais de contas. Revista do Tribunal de Contas da União, Brasília, v. 27, n. 68, p.113-122, 1996.

ALVARES, Elcio. Efeito Positivo. Revista do Tribunal de Contas da União, Brasília, v. 27, n. 70, p.37-38, 1996.

ASSIS, Araken de. Manual da execução. 11. ed. São Paulo: Revista Dos Tribunais, 2008.

BARROSO, Luís Roberto. Constituição, Democracia e Supremacia Judicial: Direito e Política no Brasil Contemporâneo. Disponível em:

$<$ http://www.lrbarroso.com.br/pt/noticias/constituicao_democracia_e_supremacia_judicial_11 032010.pdf>. Acesso em: 03 out. 2011.

BRASIL. Constituição (1988). Constituição da República Federativa do Brasil. Disponível em: <http://www.planalto.gov.br/ccivil_03/constituicao/constitui\%C3\%A7ao.htm>. Acesso em 15 nov. 2011.

BRASIL. Decreto n. 966-A, de 7 de novembro de 1890. Crêa um Tribunal de Contas para o exame, revisão e julgamento dos actos concernentes á receita e despeza da Republica. Coleção de Leis do Brasil - 1890 , p. 3440, fasc. XI (Publicação Original).

BRASIL. Lei Complementar n. 73, de 10 de fevereiro de 1993. Institui a Lei Orgânica da Advocacia-Geral da União e dá outras providências. Diário Oficial da União de 11/02/1993.

BRASIL. Lei n. 830, de 23 de setembro de 1949. Reorganiza o Tribunal de Contas da União. Diário Oficial da União de 23/09/1949.

BRASIL. Lei n. 4.320, de 17 de março de 1964. Estatui Normas Gerais de Direito Financeiro para elaboração e contrôle dos orçamentos e balanços da União, dos Estados, dos Municípios e do Distrito Federal. Diário Oficial da União de 23/03/1964. 
BRASIL. Lei n. 5.869, de 11 de janeiro de 1973. Institui o Código de Processo Civil. Diário Oficial da União de 17/11/1973.

BRASIL. Lei n. 6.830, de 22 de setembro de 1980. Dispõe sobre a cobrança judicial da Dívida Ativa da Fazenda Pública, e dá outras providências. Diário Oficial da União de 24/09/1980.

BRASIL. Lei n. 8.212, de 24 de julho de 1991. Dispõe sobre a organização da Seguridade Social, institui Plano de Custeio, e dá outras providências. Diário Oficial da União de 25/07/1991. Republicada em 11/04/1996 e 14/08/1998.

BRASIL. Lei n. 8.443, de 16 de julho de 1992. Dispõe sobre a Lei Orgânica do Tribunal de Contas da União e dá outras providências. Diário Oficial da União de 17/07/1992.

BRASIL. Lei n. 9.028, de 12 de abril de 1995. Dispõe sobre o exercício das atribuições institucionais da Advocacia-Geral da União, em caráter emergencial e provisório, e dá outras providências. Diário Oficial da União de 13/04/1995, 17/04/1995 e 19/04/1995.

BRASIL. Lei n. 9.307, de 23 de setembro de 1996. Dispõe sobre a arbitragem. Diário Oficial da União de 24/09/1996.

BRASIL. Lei n. 9.784, de 29 de janeiro de 1999. Regula o processo administrativo no âmbito da Administração Pública Federal. Diário Oficial da União de 01/02/1999.

BRASIL. Lei n. 10.480, de 2 de julho de 2002. Dispõe sobre o Quadro de Pessoal da Advocacia-Geral da União, a criação da Gratificação de Desempenho de Atividade de Apoio Técnico-Administrativo na AGU - GDAA, cria a Procuradoria-Geral Federal, e dá outras providências. Diário Oficial da União de 03/07/2002.

BRASIL. Lei n. 11.232, de 22 de dezembro de 2005. Altera a Lei ${ }^{0} 5.869$, de 11 de janeiro de 1973 - Código de Processo Civil, para estabelecer a fase de cumprimento das sentenças no processo de conhecimento e revogar dispositivos relativos à execução fundada em título judicial, e dá outras providências. Diário Oficial da União de 23/12/2005.

BRASIL. Lei n. 11.382, de 6 de dezembro de 2006. Altera dispositivos da Lei $\mathrm{n}^{\mathrm{o}}$ 5.869, de 11 de janeiro de 1973 - Código de Processo Civil, relativos ao processo de execução e a outros assuntos. Diário Oficial da União de 07/12/2006.

BRASIL. Lei n. 11.457, de 16 de março de 2007. Dispõe sobre a Administração Tributária Federal; altera as Leis nos 10.593, de 6 de dezembro de 2002, 10.683, de 28 de maio de 2003, 8.212, de 24 de julho de 1991, 10.910, de 15 de julho de 2004, o Decreto-Lei no 5.452, de 1 o de maio de 1943, e o Decreto no 70.235, de 6 de março de 1972; revoga dispositivos das Leis nos 8.212, de 24 de julho de 1991, 10.593, de 6 de dezembro de 2002, 10.910, de 15 de julho de 2004, 11.098, de 13 de janeiro de 2005, e 9.317, de 5 de dezembro de 1996; e dá outras providências. Diário Oficial da União de 19/03/2007.

BRASIL. Proposta de Emenda à Constituição n. 535, de 8 de outubro de 1997. Dá nova redação ao $\S 3^{\circ}$ do art. 71 da Constituição Federal. Disponível em:

<http://www.camara.gov.br/proposicoesWeb/fichadetramitacao;jsessionid=B6764930F81002

CFBC14EF662967810B.node1?idProposicao=14808\&ord=0>. Acesso em 15 nov. 2011. 
BRASIL. Proposta de Emenda à Constituição n. 25, de 3 de junho de 2009. Dá nova redação aos arts. 71 e 75 da Constituição Federal, com o fim de atribuir legitimidade ativa aos Tribunais de Contas para ajuizar ações de execução fundadas em suas próprias decisões dotadas de eficácia de título executivo. Disponível em:

$<$ http://www.senado.gov.br/atividade/materia/detalhes.asp?p_cod_mate=91472>. Acesso em 15 nov. 2011.

BRASIL. Superior Tribunal de Justiça. Primeira Turma. Acórdão em recurso especial n. 1032732/CE. R.S. e outros; e MPF. Relator: Ministro Luiz Fux. DJe, 03 dez. 2009.

BRASIL. Supremo Tribunal Federal. Tribunal Pleno. Acórdão em mandado de segurança n. 6960. José Macêdo e Tribunal de Contas da União. Relator: Ministro Ribeiro da Costa. DJ, 27 ago. 1959.

BRASIL. Supremo Tribunal Federal. Tribunal Pleno. Acórdão em mandado de segurança n. 7280. Hilton Santos e Tribunal de Contas da União. Relator: Ministro Henrique D'Avila. DJ, 15 mai. 1961.

BRASIL. Supremo Tribunal Federal. Tribunal Pleno. Acórdão em ação direta de inconstitucionalidade n. 849/MT. Procurador-Geral da República e Assembleia Legislativa do Estado de Mato Grosso. Relator: Ministro Sepúlveda Pertence. DJ, 23 abr. 1999.

BRASIL. Supremo Tribunal Federal. Tribunal Pleno. Acórdão em recurso extraordinário n. 223037/SE. Tribunal de Contas do Estado de Sergipe e Luiz Carlos Sigmaringa Seixas e outros. Relator: Ministro Maurício Corrêa. DJ, 02 ago. 2002.

BRASIL. Supremo Tribunal Federal. Tribunal Pleno. Acórdão em mandado de segurança n. 25880. Maria Angélica Farias de Arruda e Tribunal de Contas da União. Relator: Ministro Eros Grau. DJ, 16 mar. 2007.

BRASIL. Supremo Tribunal Federal. Tribunal Pleno. Acórdão em mandado de segurança n. 26210. Tania Costa Tribe e Tribunal de Contas da União. Relator: Ministro Ricardo Lewandowski. DJ, 10 out. 2008.

BRASIL. Tribunal de Contas da União. Plenário. Acórdão n. 1.603/2011, proferido a partir de consulta formulada pela AGU no processo TC 015.999/2010-6. Relator: Ministro Ubiratan Aguiar. Disponível em:

http://www.tcu.gov.br/Consultas/Juris/Docs/judoc/Acord/20110627/AC_1603_23_11_P.doc

BUGARIN, Paulo Soares. O princípio constitucional da economicidade na jurisprudência do Tribunal de Contas da União. Belo Horizonte: Fórum, 2004.

CALDAS, Robson Nascimento. AGU e TCU: Uma cooperação em defesa do patrimônio público. In: OLIVEIRA, Adelino Fernandes de et al. Auditoria Interna e Controle Governamental. 2. ed. Brasília: Tribunal de Contas da União, 2011. p. 321-330.

CÂMARA, Alexandre de Freitas. Lições de Direito Processual Civil. v. 2. 16 ed. Rio de Janeiro: Lumen Juris, 2008. 
CERCO ao dinheiro de origem corrupta. Jornal do Commercio, Rio de Janeiro, 9 dez. 2010. Disponível em:

$<$ http://cnj.myclipp.inf.br/default.asp?smenu=\&dtlh=143552\&iABA=Not\%EDcias\&exp=>. Acesso em 15 nov. 2011.

CHAVES, Francisco Eduardo Carrilho. Controle Externo da Gestão Pública. 2. ed. Niterói: Impetus, 2009.

CINTRA, Antonio Carlos de Araújo; GRINOVER, Ada Pellegrini; DINAMARCO, Cândido Rangel. Teoria Geral do Processo. 22. ed. São Paulo: Malheiros, 2006.

COMISSÃO EUROPEIA. Rede Judiciária Europeia em Matéria Civil e Comercial. Glossário. Disponível em: <http://ec.europa.eu/civiljustice/glossary/glossary_pt.htm\#Força executiva>. Acesso em: 03 out. 2011.

COSTA, Carlos Casimiro. Funções jurisdicionais e administrativas dos Tribunais de Contas. Revista do Tribunal de Contas do Estado da Paraíba, João Pessoa, v. 2, n. 4, p.57-89, 2003.

COSTA JÚNIOR, Eduardo Carone da. As funções jurisdicional e opinativa do Tribunal de Contas. Revista do Tribunal de Contas do Estado de Minas Gerais, Belo Horizonte, ano XIX, n. 2, p.45-115, 2001.

CUNHA, Leonardo José Carneiro da. As mudanças no processo de execução e seus reflexos na execução fiscal. In: BRUSCHI, Gilberto Gomes; SHIMURA, Sérgio. Execução civil e cumprimento de sentença. São Paulo: Método, 2007. p. 323-342.

CUSTÓDIO, A.j. Ferreira. Eficácia das decisões dos Tribunais de Contas. Revista PGE/SP, São Paulo, p.129-148, dez. 1991.

DIDIER JUNIOR, Fredie et al. Curso de Direito Processual Civil: Execução. Salvador: Jus Podivm, 2009.

DI PIETRO, Maria Sylvia Zanella. Coisa julgada: aplicabilidade a decisões do Tribunal de Contas da União. Revista do Tribunal de Contas da União, Brasília, v. 27, n. 70, p.23-36, 1996.

ESTADO DE MINAS GERAIS. Tribunal de Justiça do Estado de Minas Gerais. $4^{\mathrm{a}}$ Câmara Cível. Acórdão em agravo de instrumento n. 1.0686.07.192654-3/001. Fazenda Pública do Estado de Minas Gerais e Aelson Ferreira Gouvea. Relator: Desembargador Dárcio Lopardi Mendes. DJ, 09 ago. 2007.

ESTADO DO RIO DE JANEIRO. Lei Complementar n. 94, de 24 de outubro de 2000. Diário Oficial do Estado do Rio de Janeiro de 26/10/2000.

FERRAZ, Luciano de Araújo. Controle da administração pública: elementos para a compreensão dos tribunais de contas. Belo Horizonte: Mandamentos, 1999. 
FERRAZ, Sérgio. A Execução das Decisões dos Tribunais de Contas: Algumas Observações. In: CAMPELO, Valmir et al. O novo Tribunal de Contas: órgão protetor dos direitos fundamentais. Belo Horizonte: Fórum, 2003. p. 119-130.

FURTADO, Lucas Rocha. Curso de Direito Administrativo. Belo Horizonte: Fórum, 2007.

GIANNICO, Maricí; MONTEIRO; Vítor J. de Mello. O novo regime jurídico dos embargos à execução de título extrajudicial. In: BRUSCHI, Gilberto Gomes; SHIMURA, Sérgio. Execução civil e cumprimento de sentença. São Paulo: Método, 2007. p. 379-408.

JACOBY FERNANDES, Jorge Ulisses. Limites a revisibilidade judicial das decisões dos tribunais de contas. Revista do Tribunal de Contas da União, Brasília, v. 27, n. 70, p.39-71, 1996.

Tribunais de Contas do Brasil: jurisdição e competência. 2. ed. Belo Horizonte: Fórum, 2008.

LA ROCQUE ALMEIDA, Guilherme Henrique de. O controle externo das agências reguladoras: Fundamentos e limites da competência do Tribunal de Contas da União. 2004. 85 f. Monografia (Graduação) - Curso de Direito, Universidade de Brasília, Brasília, 2004.

LEAL, Victor Nunes. Valor das decisões do Tribunal de Contas. Revista do Tribunal de Contas do Estado da Paraíba, João Pessoa, v. 2, n. 4, p.91-105, 2003.

MARINONI, Luiz Guilherme; ARENHART, Sérgio Cruz. Execução. 2. ed. São Paulo: Revista Dos Tribunais, 2008.

MARTINEZ, Nagib Chaul. A efetividade das condenações pecuniárias do Tribunal de Contas da União em face da reapreciação judicial de suas decisões: O problema do acórdão do TCU como título executivo meramente extrajudicial. In: SOUSA JÚNIOR, Jose Geraldo de. Sociedade democrática, direito público e controle externo. Brasília: Tribunal de Contas da União, 2006. p. 479-493.

MIOLA, Cezar. Rumo à Efetividade das Decisões dos Tribunais de Contas. Disponível em:

$<$ http://portal.tce.rs.gov.br/pls/portal_prod/pk_portal_noticias.Prc_Download_BlobClip?p_not icia $=572>$. Acesso em: 08 out. 2011.

MONNERAT, Fábio Victor da Fonte. Conceito, classificação e eficácia executiva da sentença no novo regime de execução de títulos executivos judiciais. In: BRUSCHI, Gilberto Gomes; SHIMURA, Sérgio. Execução civil e cumprimento de sentença. São Paulo: Método, 2007.

RODRIGUES, Álvaro Pinto. A Atuação do Tribunal de Contas da União na Gestão Compartilhada da Saúde: Análise a Partir do Controle Social. 2009. 267 f. Dissertação (Mestrado) - Curso de Mestrado em Direito, Universidade Luterana do Brasil, Canoas, 2009.

ROSAS, Roberto. A execução das decisões dos tribunais de contas. Revista do Tribunal de Contas do Distrito Federal, Brasília, n. 11, p.119-121, 1981.

TRIBUNAL DE CONTAS DA UNIÃO. Relatório Anual de Atividades. Brasília, 2010a. 
Relatório de Cobrança Executiva. Brasília, 2010 b.

Relatório de Gestão. Brasília, 2010c.

Relatório Gerencial do Serviço de Cobrança Executiva. Brasília, 2010d.

Relatório de Gestão. Brasília, 2009.

Secretaria Adjunta de Normas e Procedimentos. Secretaria-Geral de Controle Externo. Manual de Cobrança Executiva. Versão 3.2. Brasília, 2008. 32 p.

Dispõe sobre instauração e organização de processo de tomada de contas especial e dá outras providências. Instrução Normativa-TCU n. 56, de 5 de dezembro de 2007. Diário Oficial da União de 11/12/2007.

Estabelece normas de organização e de apresentação dos relatórios de gestão e das peças complementares que constituirão os processos de contas da administração pública federal, para julgamento do Tribunal de Contas da União, nos termos do art. $7^{\circ}$ da Lei $n^{\circ}$ 8.443, de 1992. Instrução Normativa-TCU n. 63, de $\mathbf{1}^{\mathbf{0}}$ de setembro de 2010. Diário Oficial da União de 06/09/2010.

Dispõe acerca das unidades jurisdicionadas cujos responsáveis devem apresentar relatório de gestão referente ao exercício de 2011, especificando a organização, a forma, os conteúdos e os prazos de apresentação, nos termos do art. $3^{\circ}$ da Instrução Normativa TCU $n^{\circ}$ 63, de $1^{\circ}$ de setembro de 2010. Decisão Normativa-TCU n. 108, de 24 de novembro de 2010. Diário Oficial da União de 29/11/2010.

Aprova o Regimento Interno do Tribunal de Contas da União. Resolução-TCU n. 155, de 4 de dezembro de 2002.. Diário Oficial da União de 09/12/2002.

Estabelece procedimentos para a autuação de processos de cobrança executiva e para a organização da documentação a ser remetida aos órgãos/entidades responsáveis pela execução dos acórdãos condenatórios do Tribunal de Contas da União. Resolução-TCU n. 178, de 24 de agosto de 2005. Disponível em:

<http://www.tcu.gov.br/Consultas/Juris/Docs/judoc/Resol/20100921/RES2005-178.doc>. Acesso em 15 nov. 2011.

Aprova a atualização do Manual de Instrução de Processos de Tomada e Prestação de Contas. Portaria-TCU n. 105, de 23 de março de 2004. Disponível em:

<http://www.tcu.gov.br/Consultas/Juris/Docs/judoc/PORTN/20090206/PRT2004-105>.

Acesso em 15 nov. 2011.

Dispõe sobre orientações às unidades jurisdicionadas ao Tribunal quanto ao preenchimento dos conteúdos dos relatórios de gestão referentes ao exercício de 2011. Portaria-TCU n. 123, de 12 de maio de 2011. Diário Oficial da União de 16/05/2011.

TRIBUNAL DE CONTAS DO ESTADO DO RIO DE JANEIRO. Dispõe a respeito da movimentação dos integrantes do Quadro de Procuradores do Tribunal de Contas do Estado do Rio de Janeiro - TCE-RJ. Resolução TCE-RJ n. 262, de 8 de abril de 2010. Diário Oficial do Estado do Rio de Janeiro de 12/04/2010. 
ULISSES FILHO, José Viana. Da competência da execução judicial das decisões do Tribunal de Contas na comarca do Recife. Revista do Centro de Estudos Judiciários do Tribunal de Justiça de Pernambuco, Recife, ano I, n. 2, p.95-102, 2008.

VERINO, Adriano de Barros. Eficácia e execução dos acórdãos do Tribunal de Contas da União. 2005. 78 f. Monografia (Graduação) - Curso de Direito, Cento de Ensino Superior do Amapá, Macapá, 2005.

VIEIRA, Christian Garcia; LORENCINI, Marco Antonio Garcia Lopes. A penhora e a nova execução de título extrajudicial. In: BRUSCHI, Gilberto Gomes; SHIMURA, Sérgio. Execução civil e cumprimento de sentença. São Paulo: Método, 2007.

YAMADA, Wilson Issamu. A natureza jurídica dos julgamentos de contas. 2005. $93 \mathrm{f}$. Monografia (Graduação) - Curso de Direito, Universidade de São Paulo, São Paulo, 2005.

ZYMLER, Benjamin. Direito administrativo e controle. 2. ed. Belo Horizonte: Fórum, 2009.

ZYMLER, Benjamin; LA ROCQUE ALMEIDA, Guilherme Henrique de. O controle externo das concessões de serviços públicos e das parcerias público-privadas. 2. ed. Belo Horizonte: Fórum, 2008. 